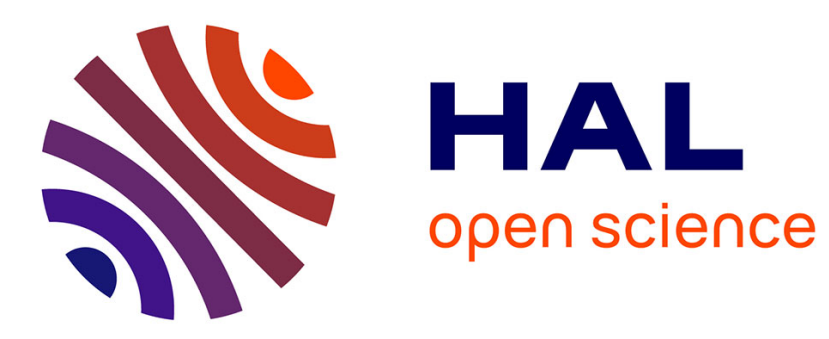

\title{
Demethylation of Methylmercury in Bird, Fish, and Earthworm
}

\author{
Alain Manceau, Jean-Paul Bourdineaud, Ricardo Oliveira, Sandra L.F. \\ Sarrazin, David Krabbenhoft, Collin Eagles-Smith, Joshua Ackerman, A. \\ Robin Stewart, Christian Ward-Deitrich, M. Estela del Castillo Busto, et al.
}

\section{To cite this version:}

Alain Manceau, Jean-Paul Bourdineaud, Ricardo Oliveira, Sandra L.F. Sarrazin, David Krabbenhoft, et al.. Demethylation of Methylmercury in Bird, Fish, and Earthworm. Environmental Science and Technology, 2021, 55 (3), pp.1527-1534. 10.1021/acs.est.0c04948 . hal-03144112

\section{HAL Id: hal-03144112 \\ https://hal.science/hal-03144112}

Submitted on 20 Mar 2021

HAL is a multi-disciplinary open access archive for the deposit and dissemination of scientific research documents, whether they are published or not. The documents may come from teaching and research institutions in France or abroad, or from public or private research centers.
L'archive ouverte pluridisciplinaire HAL, est destinée au dépôt et à la diffusion de documents scientifiques de niveau recherche, publiés ou non, émanant des établissements d'enseignement et de recherche français ou étrangers, des laboratoires publics ou privés. 


\section{Demethylation of methylmercury in bird, fish, and earthworm}

Alain Manceau ${ }^{1 *}$, Jean-Paul Bourdineaud ${ }^{2}$, Ricardo B. Oliveira ${ }^{3}$, Sandra L.F. Sarrazin ${ }^{3}$, David P. Krabbenhoft $^{4}$, Collin A. Eagles-Smith ${ }^{5}$, Joshua T. Ackerman ${ }^{6}$, A. Robin Stewart ${ }^{7}$, Christian WardDeitrich $^{8}$, M. Estela del Castillo Busto ${ }^{8}$, Heidi Goenaga-Infante ${ }^{8}$, Aude Wack ${ }^{1}$, Marius Retegan $^{9}$, Blanka Detlefs $^{9}$, Pieter Glatzel ${ }^{9}$, Paco Bustamante ${ }^{10}$, Kathryn L. Nagy ${ }^{11} \&$ Brett A. Poulin ${ }^{12,13^{*}}$

1. Université Grenoble Alpes, ISTerre, CNRS, Grenoble, France

2. Université de Bordeaux, Institut Européen de Chimie et Biologie, CNRS, Pessac, France

3. Universidade Federal do Oeste Pará, LabBBEx, Santarém, Pará, Brazil

4. U.S. Geological Survey, Upper Midwest Water Science Center, Middleton, Wisconsin, USA

5. U.S. Geological Survey, Forest and Rangeland Ecosystem Science Center, Corvallis, Oregon, USA

6. U.S. Geological Survey, Western Ecological Research Center, Dixon Field Station, Dixon, California, USA

7. U.S. Geological Survey, Water Resources Mission Area, Menlo Park, California, USA

8. National Measurement Institute, LGC Limited, Teddington, Middlesex, United Kingdom

9. European Synchrotron Radiation Facility (ESRF), Grenoble, France

10. Université La Rochelle, CNRS, Littoral Environnement et Sociétés, La Rochelle, France

11. University of Illinois at Chicago, Department of Earth and Environmental Sciences, Chicago, Illinois, USA

12. U.S. Geological Survey, Water Resources Mission Area, Boulder, Colorado, USA

13. Department of Environmental Toxicology, University of California Davis, Davis, CA 95616, USA

Correspondence to: alain.manceau@univ-grenoble-alpes.fr; $\underline{\text { bapoulin@ucdavis.edu }}$

Keywords: Mercury, selenocysteine, selenoprotein P, speciation, HR-XANES, HR-EXAFS, HPLCICPMS 


\begin{abstract}
Toxicity of methylmercury ( $\mathrm{MeHg}$ ) to wildlife and humans results from its binding to cysteine residues of proteins, forming $\mathrm{MeHg}$-cysteinate (MeHgCys) complexes that hinder biological functions. MeHgCys complexes can be detoxified in vivo, yet how this occurs is unknown. We report that $\mathrm{MeHgCys}$ complexes are transformed into selenocysteinate $\left(\mathrm{Hg}(\mathrm{Sec})_{4}\right)$ complexes in multiple animals from two phyla (a waterbird, freshwater fish, and earthworms) sampled in different geographical areas and contaminated by different $\mathrm{Hg}$ sources. In addition, high energy-resolution Xray absorption spectroscopy (HR-XAS) and chromatography-ICP mass spectrometry of the waterbird liver support the binding of $\mathrm{Hg}(\mathrm{Sec})_{4}$ to selenoprotein $\mathrm{P}$ and biomineralization of $\mathrm{Hg}(\mathrm{Sec})_{4}$ to chemically inert nanoparticulate mercury selenide $(\mathrm{HgSe})$. The results provide a foundation for understanding mercury detoxification in higher organisms, and suggest that the identified MeHgCys to $\mathrm{Hg}(\mathrm{Sec})_{4}$ demethylation pathway is common in nature.
\end{abstract}

\title{
INTRODUCTION
}

Mercury $(\mathrm{Hg})$ enters ecosystems as inorganic divalent $(\mathrm{Hg}(\mathrm{II}))$ and elemental $(\mathrm{Hg}(0))$ forms through atmospheric deposition at the global scale, and through anthropogenic point sources at the local scale. Inorganic $\mathrm{Hg}(\mathrm{II})$ is subject to methylation (to methylmercury $(\mathrm{MeHg})$ ) by microorganisms ${ }^{1}$ and is transformed to MeHg-cysteinate (MeHgCys) when taken up in multicellular organisms. MeHgCys has been reported in skeletal muscle of fish, ${ }^{2,3}$ and whales ${ }^{4}$ as well as in human brain ${ }^{5}$ and hair. ${ }^{6}$ In marine mammals and seabirds, in which the Hg burden is exceptionally high and selenium (Se) abundant, $\mathrm{MeHgCys}$ is understood to be demethylated in the form of $\mathrm{HgSe}$ and $\mathrm{Hg}(\mathrm{S}, \mathrm{Se})$ granules. ${ }^{7-12}$ No other detoxified form of MeHgCys is yet known. Attempts to characterize the HgSe granules by X-ray absorption spectroscopy have been deceptive. In crystalline $\mathrm{HgSe}$, the $\mathrm{Hg}$ atoms are tetrahedrally coordinated to 4 Se atoms at $2.635 \AA$ and surrounded by $12 \mathrm{Hg}$ neighbors at $4.30 \AA$. While $\mathrm{Hg}$-Se bond lengths between $2.59 \AA$ and $2.63 \AA$ have been reported in liver and pituitary tissues from beluga whale 
and in human brain by extended X-ray absorption fine structure (EXAFS) spectroscopy, ${ }^{5,13}$ no $\mathrm{Hg}-\mathrm{Hg}$ pairs have ever been detected in animals and human. The possibility exists that MeHgCys is detoxified to organic selenide forms prior to nanoparticulate $\mathrm{HgSe}$ nucleation.

To address this question, we investigated in vivo chemical forms of $\mathrm{Hg}$ in liver and extrahepatic tissues of the waterbird Clark's grebe (Aechmophorus clarkii) and several species of freshwater fish, and in whole bodies of earthworms. The Clark's grebe was collected from Lake Berryessa, which is impacted by mining activity in the California Coast Range (Table 1). Five piscivore fish, including three peacock bass (two Cichla temensis and one C. monoculus) and two pescada branca (Plagioscion squamosissimus), were collected in the Tapajós River in Brazil contaminated by artisanal gold mining activity (Tables S1 and S2). Earthworms $(n=13)$ were collected from two French soils impacted by $\mathrm{Hg}$ deposition from a chlor-alkali plant ${ }^{14}$ and analyzed with and without digestive tracts (Table S3).

Mercury speciation analysis was performed using high energy-resolution (HR) X-ray absorption spectroscopy (HR-XAS). ${ }^{15}$ In X-ray absorption near-edge structure (HR-XANES) mode, Hg ligands are identifiable with enhanced chemical sensitivity compared to standard XANES, and Hg-Hg pairs are detectable in biological tissues at sub-ppm $\mathrm{Hg}$ concentrations $\left(<1 \mathrm{mg}\right.$ total $\left.\mathrm{Hg} \mathrm{kg}^{-1}\right),{ }^{6,16,17}$ even when the pairs occur in nanometric HgSe precipitates. HR-XAS also provides high quality HR-EXAFS data for complementary insight into the bonding environment and local structure of $\mathrm{Hg}$. The parasitic Se K-absorption edge, which limits the energy range of the $\mathrm{Hg} \mathrm{L}_{3}$-edge EXAFS signal to $374 \mathrm{eV}(k \sim$ $\left.9.6 \AA^{-1}\right)^{18-21}$ unless Ga K-edge absorption filters are used,22, 23 is not observed at high energyresolution. ${ }^{24-26}$ The speciation of $\mathrm{Hg}$ and Se in Clark's grebe liver and muscle was also investigated by double affinity chromatography high performance liquid chromatography coupled to inductively coupled mass spectrometry (AF-HPLC-ICPMS). ${ }^{27,28}$

\section{MATERIALS AND METHODS}


Sampling and sample preparation. Clark's grebe. An adult male Clark's grebe (Aechmophorus clarkii; band \# 2097-56064) was collected from Lake Berryessa (California, United States; 38³6’31”N $122^{\circ} 14^{\prime} 33^{\prime \prime}$ W NAD 83) in September $2012^{29}$ and necropsied at the U.S. Geological Survey (Dixon, CA) to obtain the following tissues: head feather, breast feather, brain, pectoral muscle, kidneys, and liver. Tissues were lyophilized and homogenized. Clark's grebes are piscivorous, nest inland on lakes and migrate to coastal climates over the winter, and exhibit some of the highest Hg concentrations among bird species in western North America. ${ }^{30}$

Fish. Peacock bass (Cichla sp.), called "tucunaré" in the Amazon region, is a piscivore fish in the adult state, and lakes are its main habitat. The fish species are given in Table S1. Tucunaré weighs up to $10 \mathrm{~kg}$ and there is no protection from harvesting during the period of reproduction, therefore it is sold on local markets all year long. Tucanaré is not a migratory species and the fish live generally in groups; therefore, the Hg content reflects local dietary intake. Plagioscion squamosissimus, called "pescada branca" in the Amazon region, is also a piscivore fish which can exceed $10 \mathrm{~kg}$. It is a migratory fish that can swim many kilometers up and down river. The specimens used in this study were fished by artisanal fishermen in September 2018 in lakes near the community of São Luis do Tapajós ( $4^{\circ} 25^{\prime 2} 28.8^{\prime \prime} \mathrm{S} 56^{\circ} 14^{\prime} 36.5^{\prime \prime} \mathrm{W}$ NAD 83$)$ located on the Tapajós River, which borders artisanal gold mining areas where liquid $\mathrm{Hg}^{0}$ is used for gold mining.

Earthworm. Earthworms were collected in 2017-2018 from two soils (S1: 4505'13.1"N,

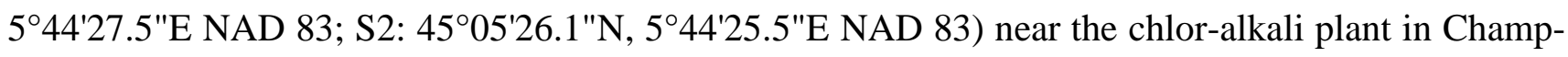
sur-Drac located $\sim 10 \mathrm{~km}$ south of Grenoble, France. Site S1 is situated approximately 250 meters to the southeast and site S2 approximately 300 meters to the northeast of the electrolytic cells. Soil samples of the topsoils (A-horizon) were taken for total $\mathrm{Hg}$ and $\mathrm{Se}$ analyses and $\mathrm{pH}$ determination. They were freeze-dried, the undecomposed organic material removed under a microscope, then sieved to $<2 \mathrm{~mm}$ and $<63 \mu \mathrm{m}$. Soil $\mathrm{pH}$ was measured on the $<2 \mathrm{~mm}$ fraction after $45 \mathrm{~min}$ agitation of $6 \mathrm{~g}$ 
soil in $15 \mathrm{~mL}$ Milli-Q water. Soil S1 had a $\mathrm{pH}$ of 7.7 and soil S2 had a $\mathrm{pH}$ of 8.0. $\mathrm{Hg}$ and Se concentrations were measured on the $<63 \mu \mathrm{m}$ fraction. Total $\mathrm{Hg}$ concentrations of soils were $\mathrm{S} 1=0.20$ $\pm 0.01 \mathrm{mg} \mathrm{kg}^{-1}$ and $\mathrm{S} 2=27.6 \pm 0.3 \mathrm{mg} \mathrm{kg}^{-1}$. A concentration of $0.23 \pm 0.02 \mathrm{mg} \mathrm{kg}^{-1}$ was reported previously in a tilled soil layer situated $900 \mathrm{~m}$ north of the plant. ${ }^{14}$ The origin of $\mathrm{Hg}$ at this site is probably atmospheric. The high concentration at the second site probably results from a $\mathrm{Hg}$ spill. The $\mathrm{Hg}$ concentration was high enough for determination of $\mathrm{Hg}$ speciation by HR-XANES spectroscopy. Figure $\mathrm{S} 1$ shows that $\mathrm{Hg}$ is mainly in the form of nanoparticulate $\beta-\mathrm{HgS}$. Total Se concentration of soil was lower at site $\mathrm{S} 1\left(0.36 \pm 0.04 \mathrm{mg} \mathrm{kg}^{-1}\right)$ compared to $\mathrm{S} 2\left(0.78 \pm 0.08 \mathrm{mg} \mathrm{kg}^{-1}\right)$.

Five endogeic and one anecic earthworms were sampled at site S1 and five endogeic and two anecic at site S2 (Table S3). Eleven out of the thirteen earthworms were rapidly frozen in liquid nitrogen then freeze-dried and crushed in a mortar for chemical and HR-XANES analysis. The digestive tract were removed from one endogeic earthworm from site $\mathrm{S} 1$ (EarthW-endo-1, $1.5 \pm 0.2 \mathrm{mg} \mathrm{Hg} \mathrm{kg}^{-1} \mathrm{dw}$ ), and one endogeic (EarthW-endo-9, $5.4 \pm 0.5 \mathrm{mg} \mathrm{Hg} \mathrm{kg}^{-1} \mathrm{dw}$ ) and one anecic (EarthW-anecic-1, $1.2 \pm 0.1$ mg $\mathrm{Hg} \mathrm{kg}^{-1} \mathrm{dw}$ ) earthworm from site S2, and the dissected earthworms were freeze-dried. All dry powders were preserved in a desiccator until analysis. The total $\mathrm{Hg}$ concentrations of the 13 earthworms ranged from 0.53 and $10.1 \mathrm{mg} \mathrm{kg}^{-1}$. The mean $\mathrm{Hg}$ concentration of endogeic earthworms is $1.9 \pm 1.0$ $\mathrm{mg} \mathrm{kg}^{-1}(n=5)$ at site $\mathrm{S} 1$ and $5.8 \pm 2.5 \mathrm{mg} \mathrm{kg}^{-1}(n=5)$ at site $\mathrm{S} 2$. Earthworms from the $\mathrm{S} 2$ site contained higher proportion of $\mathrm{MeHg}$ than those from the $\mathrm{S} 1$ site.

Methods. A detailed description of the experimental methods, including chemical, PCR, and protein analyses, SelP amino acid sequences, and HR-XANES and HR-EXAFS measurements and data reduction, is given in the Supporting Information (SI). Briefly, all samples were measured for total $\mathrm{Hg}$ and Se concentration by chemical analysis, and for $\mathrm{Hg}$ speciation by HR-XANES spectroscopy. Only the Clark's grebe liver tissue contained high enough $\mathrm{Hg}\left(43.1 \pm 4.3 \mathrm{mg} \mathrm{kg}^{-1}\right)$ for HR-EXAFS measurement. The speciation of Hg and Se in Clark's grebe liver and muscle tissues was also measured 
by AF-HPLC-ICPMS. PCR analysis was performed on soil and earthworm microflora extracted from the digestive tract for the presence of $\mathrm{Hg}$ methylation genes. The predicted tertiary structures of SelP amino acid sequences across fish, birds, and mammals were modeled. Data generated during this study are available at https://doi.org/10.5066/P96NP376. ${ }^{31}$

\section{RESULTS}

Mercury and selenium concentrations. The Clark's grebe tissues exhibited total $\mathrm{Hg}$ and Se concentrations consistent with grebes from high $\mathrm{Hg}$ locations in the Western United States, ${ }^{32}$ and a hierarchy in both element concentrations similar to those of other vertebrates (brain $<$ muscle < kidneys < liver; Table 1). ${ }^{33}$ The Clark's grebe feathers had elevated total $\mathrm{Hg}\left(40.7 \pm 4.1 \mathrm{mg} \mathrm{kg}^{-1}\right)$ and low Se levels $\left(1.04 \pm 0.10 \mathrm{mg} \mathrm{kg}^{-1}\right)$. In the three fish species, total $\mathrm{Hg}$ and Se concentrations were comparable $\left(\right.$ mean $[\mathrm{Hg}]=2.6 \pm 1.4 \mathrm{mg} \mathrm{kg}^{-1}$, mean $\left.[\mathrm{Se}]=3.0 \pm 3.0 \mathrm{mg} \mathrm{kg}^{-1}\right)$, Se concentrations were higher in liver compared to muscle (mean $[\mathrm{Se}]_{\text {liver }}=4.9 \pm 3.3 \mathrm{mg} \mathrm{kg}^{-1}$, mean $[\mathrm{Se}]_{\text {muscle }}=1.0 \pm 0.1 \mathrm{mg} \mathrm{kg}^{-1}$ ), and the relative concentration of total $\mathrm{Hg}$ in liver versus muscle samples varied across the five individuals (from 0.4 to 1.8). Total $\mathrm{Hg}$ and Se concentrations in earthworms ranged from $1.2-10.1 \mathrm{mg} \mathrm{kg}^{-1}$ and 1.0 $28.3 \mathrm{mg} \mathrm{kg}^{-1}$, respectively (mean $[\mathrm{Hg}]=3.7 \pm 2.5 \mathrm{mg} \mathrm{kg}^{-1}$, mean $\left.[\mathrm{Se}]=10.6 \pm 8.0 \mathrm{mg} \mathrm{kg}^{-1}\right)($ Tables S2 and S3).

Identification of the Hg-selenocysteinate complex in Clark's grebe. Two dominant $\mathrm{Hg}$ species occur in the Clark's grebe tissues as indicated by isosbestic points in the HR-XANES spectra, points where all spectra have the same normalized absorption (Figure 1a). The feathers and brain spectra have an intense near-edge peak at $12279.8 \mathrm{eV}$ characteristic of MeHgCys ${ }^{6,34}$ (Figure S2a). Conversely, the liver spectrum has a weak near-edge peak and the top-edge occurs at lower energy (12312-12338 eV). These differences are diagnostic of a shift in $\mathrm{Hg}$ coordination from linear in feathers and brain to tetrahedral in liver (Figure S2b). ${ }^{35}$ Muscle and kidney tissues contain variable proportions of these two 
species. The liver spectrum does not match exactly any known $\mathrm{Hg}$ spectrum, and of the tetrahedral compounds in our extended spectral database (ref. ${ }^{35}$ and refs. therein) corresponds most closely to nanoparticulate tiemannite $\left(\mathrm{HgSe}_{\mathrm{NP}}\right)$ (Figure $\left.1 \mathrm{~b}\right)$. However, the spectrum lacks oscillations in the topedge region (12300-12340 eV) that arise from multiple scattering events of the photoelectron on the 12 $\mathrm{Hg}$ atoms surrounding a central $\mathrm{Hg}$ atom in particulates. Such oscillations would be intense in wellcrystallized HgSe and less intense in nanoparticulate materials, which have wide ranges of angles and bond lengths as commonly observed for metal clusters in proteins. ${ }^{35}$ Instead, the top-edge region is bell-shaped, which indicates that little of the $\mathrm{Hg}$ occurs as $\mathrm{HgSe}$ granules of any size. The seleniol nature of the new tetrahedral $\mathrm{Hg}$ species was confirmed by HR-EXAFS spectroscopy (Figure 2). The liver HR-EXAFS data were fit with $\mathrm{Hg}$ bound on average to $2.6 \pm 0.6 \mathrm{Se}$ atoms at $2.61 \pm 0.01 \AA$ and $0.8 \pm 0.2 \mathrm{~S}$ atoms at $2.35 \pm 0.03 \AA$ in the first coordination shell, consistent with a four-fold coordination of $\mathrm{Hg}$ to $\mathrm{Se}^{36}$ for the dominant seleniol species (Figure $\mathrm{S} 3 \mathrm{a}$ ) and a two-fold coordination of $\mathrm{Hg}$ to $\mathrm{S}$ for minor MeHgCys (Table S4). The minor contribution of MeHgCys was confirmed at $18 \%$ by chemical analysis (Figure S4). We conclude that the inorganic Hg species is a tetrahedral selenolate complex with selenocysteine residues $\left(\mathrm{Hg}(\mathrm{Sec})_{4}\right)$.

The HR-XANES spectrum of $\mathrm{Hg}(\mathrm{Sec})_{4}$ was obtained by iterative transformation factor analysis (ITFA) of all data from bird, fish, and earthworm tissues, in which varying proportions of the $\mathrm{Hg}(\mathrm{Sec})_{4}$ complex were observed together with MeHgCys and a $\mathrm{Hg}$ dithiolate complex $\mathrm{Hg}(\mathrm{SR})_{2}$ (Figure S5). Cysteine is the most likely biological thiol associated with either a peptide (e.g., glutathione, GSH) or protein. Using the $\mathrm{Hg}(\mathrm{Sec})_{4}$ spectrum, the best two-component fit of the grebe liver spectrum was obtained with $86 \pm 5 \% \mathrm{Hg}(\mathrm{Sec})_{4}+14 \pm 5 \% \mathrm{MeHgCys}$, the latter represented by the Clark's grebe feather (Figure S6a and Table S5). Although the $\mathrm{Hg}(\mathrm{Sec})_{4}$ spectrum, like the grebe liver spectrum, lacks the oscillations in the top-edge region observed in $\mathrm{HgSe}_{\mathrm{NP}}$ (Figure 1b), several lines of evidence point to the co-presence of individual $\mathrm{Hg}(\mathrm{Sec})_{4}$ complexes and disordered $\mathrm{Hg}_{\mathrm{x}}(\mathrm{Se}, \mathrm{Sec})_{\mathrm{y}}$ clusters in the grebe 
liver, as in hepathic and extrahepatic tissues of giant petrels Macronectes spp. ${ }^{12}$ Careful study of the top-edge region of the $\mathrm{Hg}(\mathrm{Sec})_{4}$ spectrum shows that it slightly deviates from the Clark's grebe liver spectrum at energies where $\mathrm{HgSe}$ exhibits intense oscillations (arrows in Figure S6a). For this reason, a modest improvement in fit quality (10\%) was achieved by including $6 \% \mathrm{HgSe}$ in the fit of the grebe liver (Figure S6b), which decreased the proportion of $\mathrm{Hg}(\mathrm{Sec})_{4}$ from $86 \%$ to $80 \%$. It is likely that more than $6 \%$ of the total $\mathrm{Hg}$ is present as $\mathrm{Hg}_{\mathrm{x}}(\mathrm{Se}, \mathrm{Sec})_{\mathrm{y}}$ clusters in the grebe liver, as (1) the $\mathrm{HgSe}$ reference is a proxy for well-crystallized $\mathrm{HgSe}$ granules and does not account for disordered $\mathrm{Hg}_{\mathrm{x}}(\mathrm{Se}, \mathrm{Sec})_{\mathrm{y}}$ clusters (Figure S7), and (2) the molar ratio of Se and $\mathrm{Hg}\left(\mathrm{Se}: \mathrm{Hg}_{\text {tot }}\right.$ ) in the grebe liver is $1.1 \pm 0.2$ (Figure S8a). The existence of $\mathrm{Hg}_{\mathrm{x}}(\mathrm{Se}, \mathrm{Sec})_{\mathrm{y}}$ clusters in the grebe liver is further supported by second coordination shell fitting of the HR-EXAFS spectrum, which detects $2.1 \mathrm{Hg}$-Hg pairs at $4.46 \pm 0.03 \AA$, compared to 12 pairs at $4.30 \AA$ in crystalline HgSe (Figure 2b, Figure S9, and Table S4).

Mercury speciation in the two animal phyla. The $\mathrm{Hg}(\mathrm{Sec})_{4}$ complex was observed in the two animal phyla, and proportions of $\mathrm{Hg}$ species were obtained by least squares fitting of all HR-XANES spectra with linear combinations of MeHgCys, $\mathrm{Hg}(\mathrm{Sec})_{4}$, and $\mathrm{Hg}(\mathrm{SR})_{2}$. In the Clark's grebe, the amounts of mercury in the major $\mathrm{Hg}(\mathrm{Sec})_{4}$ complex plus minor $\mathrm{Hg}_{\mathrm{x}}(\mathrm{Se}, \mathrm{Sec})_{\mathrm{y}} / \mathrm{HgSe} \mathrm{NP}_{\mathrm{NP}}$ are $37.1 \pm 4.3$ $\mathrm{mg} \mathrm{kg}^{-1}$ in liver, $12.7 \pm 1.7 \mathrm{mg} \mathrm{kg}^{-1}$ in kidneys, and $0.7 \pm 0.3 \mathrm{mg} \mathrm{kg}^{-1}$ in muscle (Table 1 and Table S5). The $\mathrm{Hg}(\mathrm{Sec})_{4}$ species is also present in fish liver and earthworm samples in varying mixtures with MeHgCys and $\mathrm{Hg}(\mathrm{SR})_{2}$ (Tables S2 and S3), but fish muscle tissues contain exclusively MeHgCys, in line with previous XANES studies. ${ }^{2,3}$ In the fish, the proportion of total $\mathrm{Hg}$ in the liver that is $\mathrm{Hg}(\mathrm{Sec})_{4}$ correlates positively with the $[\mathrm{Hg}]_{\text {liver: }}[\mathrm{Hg}]_{\text {muscle }}$ ratio (Figure $\mathrm{S} 10$ ) and was as high as $62 \pm 5 \%$ in the liver of the fish with highest $\mathrm{Hg}$ concentration (Cichla temensis, $5.5 \mathrm{mg} \mathrm{Hg} \mathrm{kg}^{-1}$ ), suggesting that $\mathrm{Hg}(\mathrm{Sec})_{4}$ is a product of demethylation. The MeHgCys and $\mathrm{Hg}(\mathrm{Sec})_{4}$ species occur in all earthworms in proportions of $17-60 \pm 10 \%$ and $10-72 \pm 10 \%$, respectively, whereas $\mathrm{Hg}(\mathrm{SR})_{2}$ is either absent or present in proportions up to $73 \pm 10 \%$ (Table S3). Total inorganic $\mathrm{Hg}\left(\mathrm{Hg}(\mathrm{Sec})_{4}\right.$ and $\left.\mathrm{Hg}(\mathrm{SR})_{2}\right)$ in 
earthworms ranges from 39-83\%, which is lower than the 90-94\% reported in earthworms from 34 natural forest soils throughout Switzerland, ${ }^{37}$ suggesting that $\mathrm{Hg}$ methylation occurs in the two contaminated soils. The $h g c A$ gene, which is required for $\mathrm{Hg}$ methylation, was observed in the soil and within the digestive tracts of the earthworms (Figures S11, S12, and Table S6). The majority of MeHg in earthworm samples is interpreted to be in the tissue because earthworms with and without digestive tracts had comparable amounts of MeHgCys (Table S3).

Spectra with similar proportions of $\mathrm{Hg}(\mathrm{Sec})_{4}$ from the two phyla show a high degree of similarity, as demonstrated for the fish liver $(62 \pm 5 \%$, PeacockBass-3-L), an earthworm $(72 \pm 10 \%$, EarthWanecic-2), and Clark's grebe kidneys (59 $\pm 5 \%$ ) (Figure 3a,b). The proportion of $\mathrm{Hg}(\mathrm{Sec})_{4}$ derived from a linear least squares fit of the fish and earthworm spectra to the grebe kidneys spectrum is $64 \%$ (Figure 3c). Agreement between the separate estimates of $64 \%$ and $59 \% \mathrm{Hg}(\mathrm{Sec})_{4}$ in the Clark's grebe kidneys serves as an internal consistency check on the quantification of the $\mathrm{Hg}$ species (Table 1 and Table S5). Further, the accuracy of the spectral fit results was evaluated by comparing the fractional amount and concentration of MeHg obtained by HR-XANES versus chemical extraction and atomic fluorescence detection (Figure S4 and Table S7). Good agreement was observed between the two independent methods for relative abundance and concentration of MeHg (Figure S4).

\section{DISCUSSION}

The data provide strong evidence for demethylation of $\mathrm{MeHg}$ as a tetraselenolate complex in the two animal phyla. This species can be formed with low molecular weight (LMW) seleniol molecules and with selenoproteins. Selenoneine is a LMW Se-containing molecule ${ }^{38}$ small enough to form a $\mathrm{Hg}(\mathrm{Sec})_{4}$ complex (Figure $\mathrm{S} 3 \mathrm{~b}$ ), as demonstrated with a synthetic analogue. ${ }^{36}$ Of selenoproteins, only selenoprotein P (SelP) contains at least four selenocysteine residues. ${ }^{39}$ Selenoneine has been reported 
in fish, ${ }^{38}$ and $\mathrm{Hg}$-bound SelP was identified in the plasma of Inuit adults ${ }^{40}$ and miners exposed to high concentration of $\mathrm{Hg}^{41}$

SelP is mainly produced in the liver and secreted into the blood plasma where it transports Se to peripheral tissues. ${ }^{33,42}$ SelP expression was highly upregulated in the miners, supporting the idea that SelP may protect against $\mathrm{Hg}$ toxicity. SelP is also produced in lesser amounts in extrahepatic tissues. In vertebrates (goat - Capra hircus, mouse - Mus musculus), mRNA expression of SelP decreased in the order liver $>$ kidneys $>$ muscle $>$ brain. ${ }^{43,44}$ The variation of the biosynthesis activity of SelP mRNA among tissues coincides with the percentage fraction of $\mathrm{Hg}(\mathrm{Sec})_{4}$ in the Clark's grebe tissues derived from HR-XANES: $86 \pm 5 \%$ in liver, $59 \pm 5 \%$ in kidneys, $11 \pm 5 \%$ in muscle, and $\leq 5 \%$ in brain (Table S5). The speciation analysis of protein extracts ${ }^{27}$ of Clark's grebe liver and muscle tissues by AFHPLC-ICPMS supports association of $\mathrm{Hg}$ and Se with SelP (Figure 4). Good agreement between biochemistry and spectroscopy is strong evidence for the binding of $\mathrm{Hg}$ to selenoprotein $\mathrm{P}$ in the cells of the Clark's grebe and fish. Similar binding configurations have been identified between Sec residues and metal coenzymes. ${ }^{45}$ Less conclusive is the selenolate ligand in earthworm given the absence of SelP in annelids; ${ }^{46}$ perhaps it is selenoneine.

Multiple selenocysteine (Sec) alignments of SelP from fish, birds, and mammals (including humans) show that the C-terminal domain contains the consensus XUXUX ${ }^{6} U X U X$ motif (single-letter amino acid code, where $\mathrm{U}$ is Sec and $\mathrm{X}$ is any other amino acid) (Figure S13). This $\mathrm{U}$ - or Sec-rich region is the most plausible binding site for $\mathrm{Hg}$, given the proximity of the protein chain to the cytosol. This hypothesis was evaluated by modeling the tertiary structure of the XUXUX6 ${ }^{6} \mathrm{XXUX}$ amino acid region of SelP for the great crested grebe (Podiceps cristatus) and zebrafish (Danio rerio) by iterative threading assembly refinement (I-TASSER ${ }^{47}$, Figures S14 and S15). The three bird and fish models with the highest prediction score all consist of a loop with the $\mathrm{X}^{6}$ sequence forming the turn and the UXU motifs facing each other on each strand (Figure 5 and Figure S15). The predicted conformations 
are highly favorable to bind the $\mathrm{Hg}^{2+}$ ion in a tetrahedral configuration. The geometric similarity of bird and fish selenolate sites, despite having relatively low amino acid sequence identity (35\% in the C-terminal domain), suggests that this binding site is preserved in vertebrates and may have a common origin.

The most direct interpretation of the findings is that the $\mathrm{XUXUX}^{6} \mathrm{UXUX}$ SelP site in birds and fish, and selenoneine or an unknown LMW species in earthworms, bind $\mathrm{Hg}(\mathrm{II})$ as the product of $\mathrm{MeHgCys}$ demethylation. The coexistence of $\mathrm{Hg}(\mathrm{SR})_{2}$ with $\mathrm{Hg}(\mathrm{Sec})_{4}$ in numerous earthworms (Table S3) and the Clark's grebe muscle and kidney tissues (Table 1) could arise from an additional, though less prominent, demethylation pathway producing $\mathrm{Hg}(\mathrm{SR})_{2}$ or a deficiency in available selenolate. Although the $\mathrm{Hg}(\mathrm{SR})_{2} \rightarrow \mathrm{Hg}(\mathrm{Sec})_{4}$ reaction cannot be dismissed in theory, the formation of $\mathrm{Hg}(\mathrm{Sec})_{4}$ through this pathway has not been documented. More work is ultimately required to document thiolate versus selenolate competition for $\mathrm{MeHg}$ and $\mathrm{Hg}(\mathrm{II})$ at the protein level. ${ }^{23}$ In terms of reactivity, selenolate (as selenocysteine) outcompetes thiolate (as cysteine) for association with $\mathrm{MeHg},{ }^{42}$ and selenolate addition to MeHgCys is exergonic and cleaves both the $\mathrm{Hg}-\mathrm{C}$ and the $\mathrm{Hg}-\mathrm{SR}$ bonds. ${ }^{36,48,49}$ In addition, the protolytic cleavage of the $\mathrm{Hg}-\mathrm{C}$ bond is promoted when the coordination of $\mathrm{Hg}$ increases from two in the reactant (MeHgCys) to four in the product $\left(\mathrm{Hg}(\mathrm{SR})_{4},{ }^{50}\right.$ and here, $\left.\mathrm{Hg}(\mathrm{Sec})_{4}\right)$. The strictly conserved XUXUX ${ }^{6} U X U X$ motif of SelP may serve as a catalytic site for the demethylation of $\mathrm{MeHg}$, analogous to cysteine residues in the organomercurial lyase $\mathrm{MerB} .{ }^{51} \mathrm{MeHg}$ demethylation by selenoneine has been demonstrated in vitro in fish blood cells and human embryonic kidney cells. ${ }^{52}$

Placed in a broader context, the results presented here fuel the idea that the C-terminal domain of SelP acts as a nucleation center for the formation of $\mathrm{HgSe}$ in vertebrates, driving in vivo MeHgCys detoxification. This finding is based on the following observations: (1) $\mathrm{Hg}$ is four-coordinate in $\mathrm{Hg}(\mathrm{Sec})_{4}$ and $\mathrm{HgSe}$; (2) the $\mathrm{Se}: \mathrm{Hg}_{\text {tot }}$ molar ratio of the $\mathrm{HgSe}$ grains in the liver of pilot whales is above 
1 as the grain size diminishes and in tissue surrounding the grain aggregates, ${ }^{11}$ which suggests that the grains are embedded in a SelP-rich matrix having a Se:Hg tot ratio approaching and above 4; (3) here, the $\mathrm{Se}: \mathrm{Hg}(\mathrm{Sec})_{4}$ ratio is always greater than 4, as expected if there is a $\mathrm{Hg}(\mathrm{Sec})_{4}$ complex, except in the Clark's grebe liver $\left(\mathrm{Se}: \mathrm{Hg}(\mathrm{Sec})_{4}=1.3 \pm 0.2\right)$ and kidneys $\left(\mathrm{Se}: \mathrm{Hg}(\mathrm{Sec})_{4}=2.1 \pm 0.3\right)$ (Figure S8b), the former confirmed to contain $\mathrm{Hg}_{\mathrm{x}}(\mathrm{Se}, \mathrm{Sec})_{\mathrm{y}} / \mathrm{HgSe}_{\mathrm{NP}}$ (Figure S9); (4) the C-terminal domain of SelP contains six UXU motifs, which could seed the formation of $\mathrm{Hg}_{\mathrm{x}}(\mathrm{Se}, \mathrm{Sec})_{\mathrm{y}}$ clusters. $^{12}$ These considerations show how $\mathrm{Hg}$ speciation results, elemental $\mathrm{Se}: \mathrm{Hg}$ ratios, and protein analyses can be reconciled to provide a foundation for understanding the process of HgSe formation. A similar nucleation mechanism has been proposed for the formation of $\mathrm{Hg}_{4}(\mathrm{Cys})_{12}$ clusters from a $\mathrm{Hg}(\mathrm{Cys})_{2}$ complex and five proximal CXC motifs in metallothionein. ${ }^{35} \mathrm{In}$ SelP, we propose that $\mathrm{Hg}$ binds to the XUXUX 6 UXUX site at low concentration, forms highly disordered $\mathrm{Hg}_{\mathrm{x}}(\mathrm{Se}, \mathrm{Sec})_{\mathrm{y}}$ clusters through metallophilic interactions ${ }^{16,35,53,54}$ in the C-terminal domain at higher concentration, and finally precipitates as $\mathrm{HgSe}$ by self-assembly of the $\mathrm{Hg}_{\mathrm{x}}(\mathrm{Se}, \mathrm{Sec})_{\mathrm{y}}$ scaffolds in highly exposed or older vertebrates. $\mathrm{Hg}_{\mathrm{x}}(\mathrm{Se}, \mathrm{Sec})_{\mathrm{y}}$ growth may occur through catalysis of MeHgCys demethylation at nanoparticle surfaces. Structural sketches of the $\operatorname{Hg}_{x}(\mathrm{Se}, \mathrm{Sec})_{\mathrm{y}}$ biotemplates, inspired from the topology of the metal clusters in vertebrate, invertebrate, and bacterial metallothioneins, are shown in Figures S7a and S16. Biomineralization by protein assemblies with high symmetry is common in nature ${ }^{55}$. The proposed reaction pathway is probably how $\mathrm{Hg}$ is detoxified as $\mathrm{HgSe}$ in human brain ${ }^{5}$ and seabirds. ${ }^{12}$ The binding of $\mathrm{Hg}$ to SelP may, however, deplete neuronal and glial cells in organo-Se essential to selenoenzyme synthesis and activity. ${ }^{42}$ It may also alter the antioxidant function of SelP..$^{33,42}$

\section{REFERENCES}

(1) Villar, E.; Cabrol, L.; Heimbürger-Boavida, L. E. Widespread microbial mercury methylation genes in the global ocean. Environ. Microbiol. Rep. 2020, 12, 277-287. 
(2) Harris, H. H.; Pickering, I. J.; George, G. N. The chemical form of mercury in fish. Science 2003, 301, 1203.

(3) Kuwabara, J. S.; Arai, Y.; Topping, B. R.; Pickering, I. J.; George, G. N. Mercury speciation in piscivorous fish from mining-impacted reservoirs. Environ. Sci. Technol. 2007, 41, 2745-2749.

(4) George, G. N.; MacDonald, T. C.; Korbas, M.; Singh, S. P.; Myers, G. J.; Watson, G. E.; O'Donoghue, J. L.; Pickering, I. J. The chemical forms of mercury and selenium in whale skeletal muscle. Metallomics 2011, 3, 1232-1237.

(5) Korbas, M.; O'Donoghue, J. L.; Watson, G. E.; Pickering, I. J.; Singh, S. P.; Myers, G. J.; Clarkson, T. W.; George, G. N. The chemical nature of mercury in human brain following poisoning or environmental exposure. ACS Chem. Neurosci. 2010, 1, 810-818.

(6) Manceau, A.; Enescu, M.; Simionovici, A.; Lanson, M.; Gonzalez-Rey, M.; Rovezzi, M.; Tucoulou, R.; Glatzel, P.; Nagy, K. L.; Bourdineaud, J.-P. Chemical forms of mercury in human hair reveal sources of exposure. Environ. Sci. Technol. 2016, 50, 10721-10729.

(7) Arai, T.; Ikemoto, T.; Hokura, A.; Terada, Y.; Kunito, T.; Tanabe, S.; Nakai, I. Chemical forms of mercury and cadmium accumulated in marine mammals and seabirds as determined by XAFS analysis. Environ. Sci. Technol. 2004, 38, 6468-6474.

(8) Nakazawa, E.; Ikemoto, T.; Hokura, A.; Terada, Y.; Kunito, T.; Tanabe, S.; Nakai, I. The presence of mercury selenide in various tissues of the striped dolphin: evidence from $\mu$-XRF-XRD and XAFS analyses. Metallomics 2011, 3, 719-725.

(9) Lailson-Brito, J.; Cruz, R.; Dorneles, P. R.; Andrade, L.; Azevedo, A. D.; Fragoso, A. B.; Vidal, L. G.; Costa, M. B.; Bisi, T. L.; Almeida, R.; Carvalho, D. P.; Bastos, W. R.; Malm, O. Mercuryselenium relationships in liver of Guiana dolphin: The possible role of Kupffer cells in the detoxification process by tiemannite formation. Plos One 2012, 7, n e42162. 
(10) Sakamoto, M.; Itai, T.; Yasutake, A.; Iwasaki, T.; Yasunaga, G.; Fujise, Y.; Nakamura, M.; Murata, K.; Chan, H. M.; Domingo, J. L.; Marumoto, M. Mercury speciation and selenium in toothedwhale muscles. Environ. Res. 2015, 143, 55-61.

(11) Gajdosechova, Z.; Lawan, M. M.; Urgast, D. S.; Raab, A.; Scheckel, K. G.; Lombi, E.; Kopittke, P. M.; Loeschner, K.; Larsen, E. H.; Woods, G.; Brownlow, A.; Read, F. L.; Feldmann, J.; Krupp, E. M. In vivo formation of natural HgSe nanoparticles in the liver and brain of pilot whales. Sci. Rep. 2016, 6,34361 .

(12) Manceau, A.; Gaillot, A. C.; Glatzel, P.; Bustamante, P. In vivo formation of HgSe nanoparticles and $\mathrm{Hg}$-tetraselenolate complex from methylmercury in seabird - Implications for the $\mathrm{Hg}-\mathrm{Se}$ antagonism. Environ. Sci. Technol. 2021, In press.

(13) Huggins, F. E.; Raverty, S. A.; Nielsen, O. S.; Sharp, N. E.; Robertson, J. D.; Ralston, N. V. C. An XAFS investigation of mercury and selenium in Beluga whale tissues. Environ. Bioindic. 2009, 4, 291-302.

(14) Guédron, S.; Grangeon, S.; Jouravel, G.; Charlet, L.; Sarret, G. Atmospheric mercury incorporation in soils of an area impacted by a chlor-alkali plant (Grenoble, France): Contribution of canopy uptake. Sci. Tot. Environ. 2013, 445, 356-364.

(15) Rovezzi, M.; Lapras, C.; Manceau, A.; Glatzel, P.; Verbeni, R. High energy-resolution x-ray spectroscopy at ultra-high dilution with spherically bent crystal analyzers of $0.5 \mathrm{~m}$ radius. Rev. Sci. Instr. 2017, 88, 013108.

(16) Manceau, A.; Wang, J.; Rovezzi, M.; Glatzel, P.; Feng, X. Biogenesis of mercury-sulfur nanoparticles in plant leaves from atmospheric gaseous mercury. Environ. Sci. Technol. 2018, 52, $3935-3948$. 
(17) Bourdineaud, J. P.; Gonzalez-Rey, M.; Rovezzi, M.; Gatzel, P.; Nagy, K. L.; Manceau, A. Divalent mercury from dissolved organic matter is bioavailable to fish and accumulates as dithiolate and tetrathiolate complexes. Environ. Sci. Technol. 2019, 53, 4880-4891.

(18) Gailer, J.; George, G. N.; Pickering, I. J.; Madden, S.; Prince, R. C.; Eileen Y. Yu; Denton, M. B.; Younis, H. S.; Aposhian, H. V. Structural basis of the antagonism between inorganic mercury and selenium in mammals. Chem. Res. Toxicol. 2000, 13, 1135-1142.

(19) Nagy, K. L.; Manceau, A.; Gasper, J. D.; Ryan, J. N.; Aiken, G. R. Metallothionein-like multinuclear clusters of mercury(II) and sulfur in peat. Environ. Sci. Technol. 2011, 45, 7298-7306.

(20) Dunham-Cheatham, S.; Mishra, B.; Myneni, S.; Fein, J. B. The effect of natural organic matter on the adsorption of mercury to bacterial cells. Geochim. Cosmochim. Acta 2015.

(21) Poulin, B. A.; Gerbig, C. A.; Kim, C. S.; Stegemeier, J. P.; Ryan, J. N.; Aiken, G. R. Effects of sulfide concentration and dissolved organic matter characteristics on the structure of nanocolloidal metacinnabar. Environ. Sci. Technol. 2017, 51, 13133-13142.

(22) Korbas, M.; Percy, A. J.; Gailer, J.; George, G. N. A possible molecular link between the toxicological effects of arsenic, selenium and methylmercury: methylmercury(II) seleno bis $(S$ glutathionyl) arsenic(III). J. Biol. Inorg. Chem. 2008, 13, 461-470.

(23) Pickering, I. J.; Cheng, Q.; Rengifo, E. M.; Nehzati, S.; Dolgova, N. V.; Kroll, T.; Sokaras, D.; George, G. N.; Arner, E. S. J. Direct observation of methylmercury and auranofin binding to selenocysteine in thioredoxin reductase. Inorg Chem. 2020, 59, 2711-2718.

(24) Glatzel, P.; de Groot, F. M. F.; Manoilova, O.; Grandjean, D.; Weckhuysen, B. M. Rangeextended EXAFS at the L edge of rare earths using high-energy-resolution fluorescence detection: A study of La in LaOCl. Phys. Rev. B 2005, 72, n 014117. 
(25) Pushkar, Y.; Yano, J.; Glatzel, P.; Messinger, J.; Lewis, A.; Sauer, K.; Bergmann, U.; Yachandra, V. Structure and orientation of the $\mathrm{Mn}_{4} \mathrm{Ca}$ cluster in plant photosystem II membranes studied by polarized range-extended X-ray absorption spectroscopy. J. Biol. Chem. 2007, 282, 7198-7208.

(26) Bianchini, M.; Glatzel, P. A tool to plan photon-in/photon-out experiments: count rates, dips and self-absorption. J. Synch. Rad. 2012, 19, 911-919.

(27) Busto, M. E. D.; Oster, C.; Cuello-Nunez, S.; Deitrich, C. L.; Raab, A.; Konopka, A.; Lehmann, W. D.; Goenaga-Infante, H.; Fisicaro, P. Accurate quantification of selenoproteins in human plasma/serum by isotope dilution ICP-MS: focus on selenoprotein P. J. Anal. At. Spectrom. 2016, 31, 1904-1912.

(28) Gajdosechova, Z.; Mester, Z.; Feldmann, J.; Krupp, E. M. The role of selenium in mercury toxicity - Current analytical techniques and future trends in analysis of selenium and mercury interactions in biological matrices. Trac-Trend. Anal. Chem. 2018, 104, 95-109.

(29) Ackerman, J. T.; Hartman, C. A.; Eagles-Smith, C. A.; Herzog, M. P.; Davis, J.; Ichikawa, G.; Bonnema, A. Estimating mercury exposure of piscivorous birds and sport fish using prey fish monitoring. Environ. Sci. Technol. 2015, 49, 13596-13604.

(30) Ackerman, J. T.; Eagles-Smith, C. A.; Herzog, M. P.; Hartman, C. A.; Peterson, S. H.; Evers, D. C.; Jackson, A. K.; Elliott, J. E.; Vander Pol, S. S.; Bryan, C. E. Avian mercury exposure and toxicological risk across western North America: A synthesis. Sci. Tot. Environ. 2016, 568, 749-769.

(31) Poulin, B. A.; Manceau, A.; Krabbenhoft, D. P.; Stewart, A. R.; Ward-Deitrich, C.; del Castillo Busto, M. E.; Goenaga-Infante, H.; Bustamante, P. Mercury and selenium chemical characteristics and speciation data of bird, fish, and earthworm tissues: U.S. Geological Survey data release, . 2020, https://doi.org/10.5066/P96NP376.

(32) Burger, J.; Jehl, J. R.; Gochfeld, M. Selenium:mercury molar ratio in eared grebes (Podiceps nigricollis) as a possible biomarker of exposure. Ecol. Indic. 2013, 34, 60-68. 
(33) Burk, R. F.; Hill, K. E. Regulation of selenium metabolism and transport. In Annu. Rev. Nutr., Bowman, B. A.; Stover, P. J., Eds. 2015; Vol. 35, pp 109-134.

(34) Thomas, S. A.; Mishra, B.; Myneni, S. C. B. Cellular mercury coordination environment, and not cell surface ligands, influence bacterial methylmercury production. Environ. Sci. Technol. 2020, 54, 3960-3968.

(35) Manceau, A.; Bustamante, P.; Haouz, A.; Bourdineaud, J. P.; Gonzalez-Rey, M.; Geertsen, V.; Barruet, E.; Rovezzi, M.; Glatzel, P.; Pin, S. Mercury(II) binding to metallothionein in Mytilus edulis revealed by high energy-resolution XANES spectroscopy. Chem-Eur J. 2019, 25, 997-1009.

(36) Palmer, J. H.; Parkin, G. Protolytic cleavage of Hg-C bonds induced by 1-methyl-1,3-dihydro2H-benzimidazole-2-selone: Synthesis and structural characterization of mercury complexes. J. Am. Chem. Soc. 2015, 137, 4503-4516.

(37) Rieder, S. R.; Brunner, I.; Horvat, M.; Jacobs, A.; Frey, B. Accumulation of mercury and methylmercury by mushrooms and earthworms from forest soils. Environ. Poll. 2011, 159, 2861-2869. (38) Yamashita, Y.; Yamashita, M. Identification of a novel selenium-containing compound, selenoneine, as the predominant chemical form of organic selenium in the blood of bluefin tuna. J. Biol. Chem. 2010, 285, 18134-18138.

(39) Labunskyy, V. M.; Hatfield, D. L.; Gladyshev, V. N. Selenoproteins: Molecular pathways and physiological roles. Physiol. Rev. 2014, 94, 739-777.

(40) Achouba, A.; Dumas, P.; Ouellet, N.; Lemire, M.; Ayotte, P. Plasma levels of seleniumcontaining proteins in Inuit adults from Nunavik. Environ. Intern. 2016, 96, 8-15.

(41) Chen, C. Y.; Yu, H. W.; Zhao, J. J.; Li, B.; Qu, L. Y.; Liu, S. P.; Zhang, P. Q.; Chai, Z. F. The roles of serum selenium and selenoproteins on mercury toxicity in environmental and occupational exposure. Environ. Health Perspect. 2006, 114, 297-301. 
(42) Ralston, N. V. C.; Raymond, L. J. Mercury's neurotoxicity is characterized by its disruption of selenium biochemistry. BBA-Gen. Sub. 2018, 1862, 2405-2416.

(43) Wang, Q.; Zhang, C. X.; Ren, Y. S.; Yue, W. B.; Shi, L. G.; Lei, F. L. Molecular structure, expression analysis and functional characterization of selenoprotein P (SEPP1) in goat (Capra hircus). J. Anim. Vet. Adv. 2012, 11, 2898-2904.

(44) Hill, K. E.; Wu, S.; Motley, A. K.; Stevenson, T. D.; Winfrey, V. P.; Capecchi, M. R.; Atkins, J. F.; Burk, R. F. Production of selenoprotein P (Sepp1) by hepatocytes is central to selenium homeostasis. J. Biol. Chem. 2012, 287, 40414-40424.

(45) Reich, H. J.; Hondal, R. J. Why Nature chose selenium. ACS Chem. Biol. 2016, 11, 821-841.

(46) Jiang, L.; Ni, J. Z.; Liu, Q. Evolution of selenoproteins in the metazoan. BMC Genomics 2012, 13.

(47) Yang, J.; Yan, R.; Roy, A.; Xu, D.; Poisson, J.; Zhang, Y. The I-TASSER Suite: Protein structure and function prediction. Nat. Methods 2015, 12, 7-8.

(48) Khan, M. A. K.; Wang, F. Y. Chemical demethylation of methylmercury by selenoamino acids. Chem. Res. Toxicol. 2010, 23, 1202-1206.

(49) Asaduzzaman, A.; Schreckenbach, G. Degradation Mechanism of Methyl Mercury Selenoamino Acid Complexes: A Computational Study. Inorganic Chemistry 2011, 50, 2366-2372.

(50) Melnick, J. G.; Yurkerwich, K.; Parkin, G. Synthesis, structure, and reactivity of two-coordinate mercury alkyl compounds with sulfur ligands: Relevance to mercury detoxification. Inorg. Chem. 2009, 48, 6763-6772.

(51) Melnick, J. G.; Parkin, G. Cleaving mercury-alkyl bonds: A functional model for mercury detoxification by MerB. Science 2007, 317, 225-227.

(52) Yamashita, M.; Yamashita, Y.; Suzuki, T.; Kani, Y.; Mizusawa, N.; Imamura, S.; Takemoto, K.; Hara, T.; Hossain, M. A.; Yabu, T.; Touhata, K. Selenoneine, a novel selenium-containing compound, 
mediates detoxification mechanisms against methylmercury. Accumulation and toxicity in zebrafish embryo. Mar. Biotechnol. 2013, 15, 559-570.

(53) Pyykko, P.; Straka, M. Ab initio studies of the dimers $\left(\mathrm{HgH}_{2}\right)_{2}$ and $\left(\mathrm{HgMe}_{2}\right)_{2}$. Metallophilic attraction and the van der Waals radii of mercury. Phys. Chem. Chem. Phys. 2000, 2, 2489-2493.

(54) Pyykko, P. Relativistic effects in chemistry: More common than you thought. Annu. Rev. Phys. Chem. 2012, 63, 45-64.

(55) Pozzi, C.; Ciambellotti, S.; Bernacchioni, C.; Di Pisa, F.; Mangani, S.; Turano, P. Chemistry at the protein-mineral interface in L-ferritin assists the assembly of a functional ( $\mu^{3}$-oxo)Tris ( $\mu^{2}$-peroxo) triiron(III) cluster. Proc. Natl. Acad. Sci. U.S.A. 2017, 114, 2580-2585.

\section{ASSOCIATED CONTENT}

\section{Supporting Information}

The Supporting Information is available free of charge on the ACS Publications website at DOI:

Materials and methods, supplementary tables and figures, Cartesian coordinates of the $\mathrm{Hg}$ (selenoneine) $)_{4}$ complex and the $\mathrm{Hg}_{10}(\mathrm{SeMe})_{20}$ cluster (PDF).

HR-XANES spectra (Excel).

\section{Data availability}

All data supporting the findings of this study are available within the paper and have been deposited in the U.S. Geological Survey repository ScienceBase. ${ }^{31}$ The deposit includes all HR-XANES spectra, the Hg L3-edge HR-EXAFS spectrum of the Clark's grebe liver, and the Cartesian coordinates of the $\mathrm{Hg}(\text { selenoneine })_{4}$ complex and the $\mathrm{Hg}_{10}(\mathrm{SeMe})_{20}$ cluster.

\section{AUTHOR INFORMATION}

Corresponding Authors

E-mail: alain.manceau@univ-grenoble-alpes.fr

E-mail: bapoulin@ucdavis.edu

\section{ORCID}

Alain Manceau: 0000-0003-0845-611X 
Kathryn Nagy: 0000-0002-4997-7547

Pieter Glatzel: 0000-0001-6532-8144

Jean-Paul Bourdineaud: 0000-0002-1619-7050

Christian Ward-Deitrich: 0000-0002-5204-2443

M.Estela del Castillo Busto: 0000-0001-6595-5236

Heidi Goenaga-Infante: 0000-0002-2416-9666

Brett Poulin: 0000-0002-5555-7733

David Krabbenhoft: 0000-0003-1964-5020

Collin Eagles-Smith: 0000-0003-1329-5285

Joshua Ackerman: 0000-0002-3074-8322

A. Robin Stewart: 0000-0003-2918-546X

\section{Notes}

The authors declare no competing financial interests.

\section{ACKNOWLEDGEMENTS}

Support was provided to A.M, J-P.B. and K.L.N. by the French National Research Agency (ANR) under grant ANR-12-BS06-0008-01, to A.M. and P.G. by the ANR under grant ANR-10-EQPX-27-01 (EcoX Equipex), to B.A.P. and K.L.N. by the U.S. National Science Foundation under grants EAR1629698 and EAR-1628956, to B.A.P, D.P.K., A.R.S., C.A.E., and J.T.A. by the U.S. Geological Survey (USGS) Environmental Health Mission Area's Toxic Substances Hydrology Program and Contaminants Biology Program, and to P.B. by the Institut Universitaire de France. The Froggy platform of the CIMENT infrastructure (ANR Grant ANR-10-EQPX- 29-01) provided computing resources and Pierre Girard contributed his expertise in parallel scientific processing. We thank Sarah Janssen (USGS) and Grégoire Pascaud (LIENs) for assistance with Hg and Se measurements, Stéphane Guédron (ISTerre) for valuable discussions on $\mathrm{Hg}$ biogeochemistry, and Andrea Foster (USGS) who provided useful comments on the manuscript. Any use of trade, firm, or product names is for descriptive purposes only and does not imply endorsement by the U.S. Government.

\section{Legends of Figures}

Figure 1. Mercury coordination in the Clark's grebe derived from $\mathrm{Hg} \mathrm{L}_{3}$-edge HR-XANES. a) Spectra from the grebe tissues. b) Spectrum of the $\mathrm{Hg}$ tetraselenocysteine complex $\left(\mathrm{Hg}(\mathrm{Sec})_{4}\right)$ with spectra 
from well-crystallized and nanoparticulate $\mathrm{HgSe}\left(\mathrm{HgSe}_{\mathrm{NP}}\right)$. The linear coordination of $\mathrm{Hg}$ in $\mathrm{MeHgCys}$ and a portion of the $\mathrm{HgSe}$ structure are represented in inset. Dark red, purple, yellow, gray, and light gray spheres represent $\mathrm{Hg}, \mathrm{Se}, \mathrm{S}, \mathrm{C}$, and $\mathrm{H}$, respectively.

Figure 2. Mercury $\mathrm{L}_{3}$-edge HR-EXAFS data of the Clark's grebe liver. a) HR-EXAFS spectrum fit with $\mathrm{Hg}$-Se and $\mathrm{Hg}$-S pairs in the first coordination shell and $\mathrm{Hg}$-Hg-pairs in the second coordination shell, and fit residual. b) Fourier transform of the HR-EXAFS spectrum and fit. Interatomic distances are not corrected for phase-shift $(\Delta R)$.

Figure 3. Mercury coordination in peacock bass and earthworm derived from $\mathrm{Hg} \mathrm{L}_{3}$-edge HR-XANES. a) Comparison of the fish liver spectrum from the individual having the highest proportion of $\mathrm{Hg}(\mathrm{Sec})_{4}$ (PeacockBass-3-L; $62 \pm 5 \%$, Table S2) with the spectrum from the Clark's grebe kidneys (59 $\pm 5 \%$ $\left.\mathrm{Hg}(\mathrm{Sec})_{4}\right)$. b) Comparison of the earthworm spectrum from the individual having the highest proportion of $\mathrm{Hg}(\mathrm{Sec})_{4}(72 \pm 10 \%$, Table S3) with the spectrum from the Clark's grebe kidneys. c, Fit of the Clark's grebe kidneys spectrum with $60 \%$ fish spectrum and $40 \%$ earthworm spectrum. The calculated proportion of $\mathrm{Hg}(\mathrm{Sec})_{4}$ is $(0.60 \times 0.61)+(0.40 \times 0.69)=64 \%$, close to the nominal value of $59 \%$. NSS is the normalized sum-squared residual expressed as $\Sigma\left[\left(\mathrm{y}_{2}-\mathrm{y}_{1}\right)^{2}\right] / \Sigma\left(\mathrm{y}_{2}{ }^{2}\right)$.

Figure 4. Double affinity chromatograms of Se (red lines) and $\mathrm{Hg}$ (blue lines) of Clark's grebe liver extract (a) and Clark's grebe muscle extract (b) by AF-HPLC-ICPMS. The Se species of each peak are as follows: peak 1, P1 (glutathione peroxidase 3; GPX3 and other non-retained species, e.g., inorganic Se and LMW Se species), peak 2, P2 (heparin-binding selenoproteins; likely selenoprotein P, SelP) and peak 3, P3 (Se-albumin; SeAlb). Chromatograms show that, of the Se species, the majority of $\mathrm{Hg}$ is associated with P2 (87.8 $\pm 0.4 \%$ and $84.3 \pm 0.7 \%$ in liver and muscle, respectively).

Figure 5. Modeled tertiary structure of SelP. a) Ribbon representation of the SelP protein for zebrafish (Danio rerio), as a proxy for peacock bass. b,c) Amino-acid sequence and predicted structure of the $\mathrm{UXUX}^{6} \mathrm{UXU}$ region of the C-terminal domain of SelP for the great crested grebe (Podiceps cristatus), as a proxy for the Clark's grebe (b), and zebrafish, as a proxy for peacock bass (Cichla sp.) and pescada branca (Plagioscion squamosissimus) (c). U is the single-letter selenocysteine (Sec) code. Purple, red, and blue represent selenol, carboxyl/hydroxyl, and amino groups from amino-acid side chains, respectively. Other models are shown in Figure S16. 
Table 1. Total concentrations $\left(\mathrm{mg} \mathrm{kg}^{-1}\right)$ of $\mathrm{Hg}$ and Se determined by chemical analysis, and concentrations of $\mathrm{MeHg}, \mathrm{Hg}$ tetraselenolate, and $\mathrm{Hg}$ dithiolate determined by HR-XANES in Clark's grebe ( $\mathrm{mg} \mathrm{Hg} \mathrm{kg}^{-1}$ dry weight).

\begin{tabular}{lccccc}
\hline Tissue & {$\left[\mathbf{H g}_{\text {Tot }}\right.$} & {$[\mathbf{S e}]_{\text {Tot }}$} & {$[\mathrm{MeHgCys}]$} & {$\left[\mathbf{H g}(\mathbf{S e c})_{4}\right]^{\mathbf{a}}$} & $\mathbf{H g}(\mathbf{S R})_{\mathbf{2}}$ \\
\hline Breast feather & $40.7 \pm 4.1$ & $1.04 \pm 0.10$ & $40.7 \pm 4.6$ & $0.0 \pm 2.1$ & $0.0 \pm 2.1$ \\
Brain & $3.1 \pm 0.3$ & $1.55 \pm 0.16$ & $3.1 \pm 0.3$ & $0.0 \pm 0.2$ & $0.0 \pm 0.2$ \\
Muscle & $6.5 \pm 0.7$ & $2.31 \pm 0.23$ & $4.3 \pm 0.5$ & $0.7 \pm 0.3$ & $1.5 \pm 0.4$ \\
Kidneys & $21.6 \pm 2.2$ & $10.6 \pm 1.0$ & $6.0 \pm 1.2$ & $12.7 \pm 1.7$ & $2.6 \pm 1.1$ \\
Liver & $43.1 \pm 4.3$ & $19.3 \pm 1.9$ & $6.0 \pm 2.2$ & $37.1 \pm 4.3$ & $0.0 \pm 2.1$ \\
\hline
\end{tabular}

${ }^{\mathrm{a}} \mathrm{Minor} \mathrm{Hg}_{\mathrm{x}}(\mathrm{Se}, \mathrm{Sec})_{\mathrm{y}} / \mathrm{HgSe}_{\mathrm{NP}}$ species are not modeled independent of $\mathrm{Hg}(\mathrm{Sec})_{4}$, because the amount cannot be quantified. 

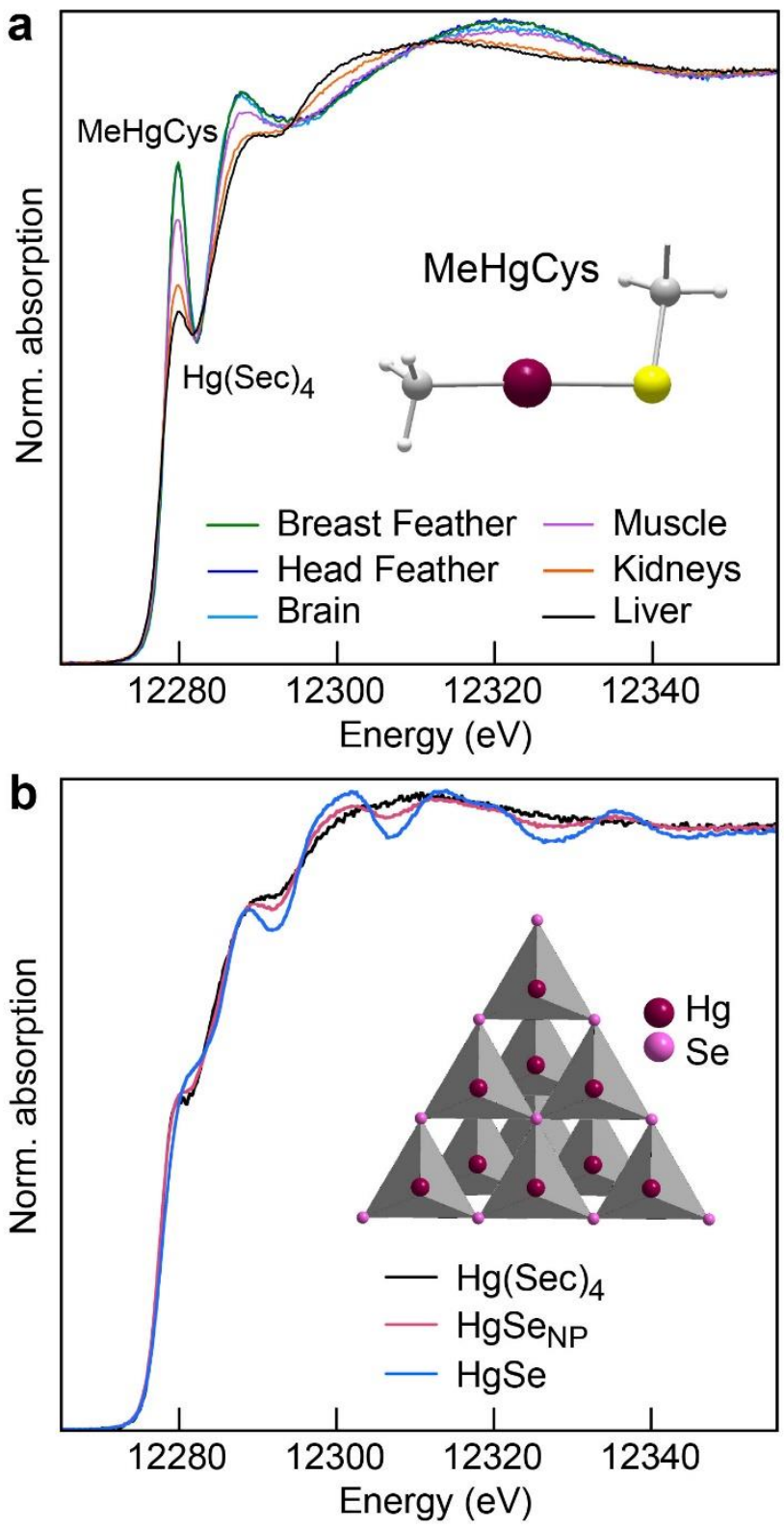

Figure 1 

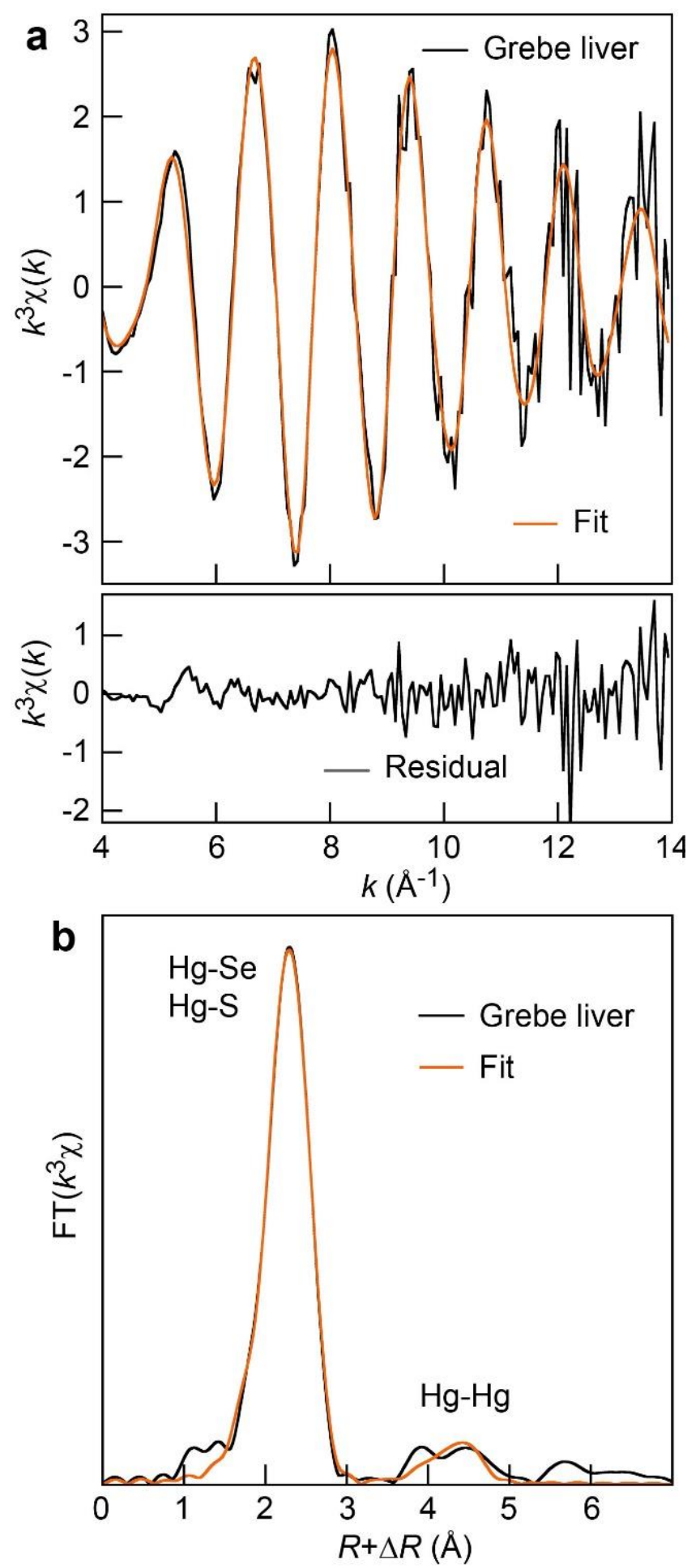

Figure 2 

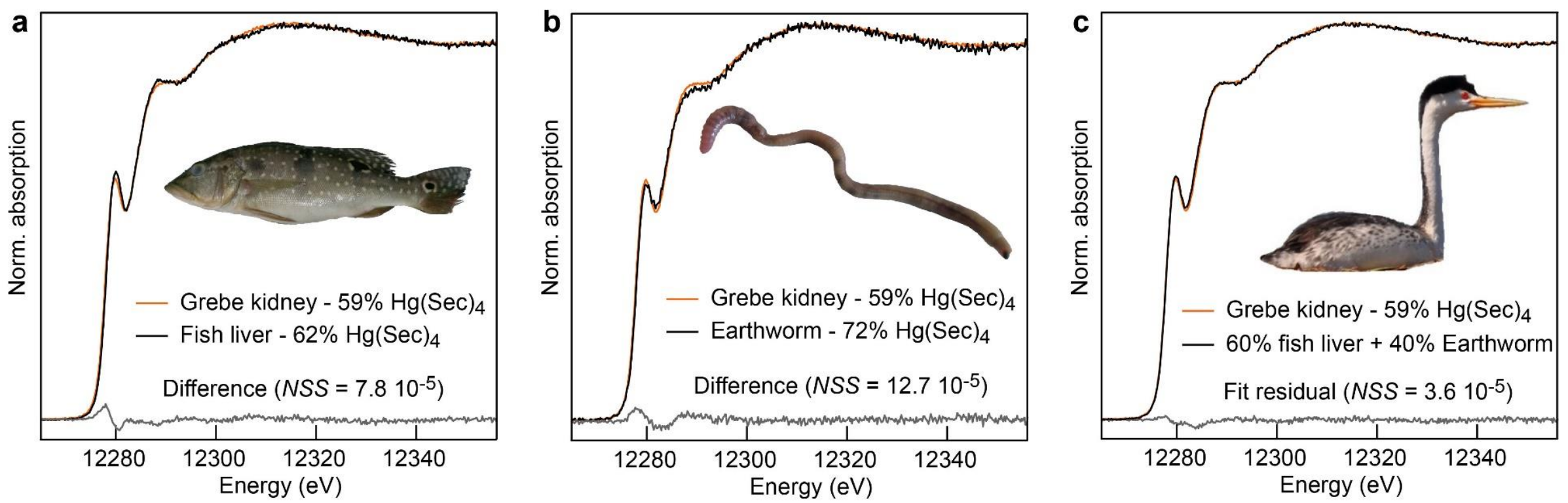

Figure 3 

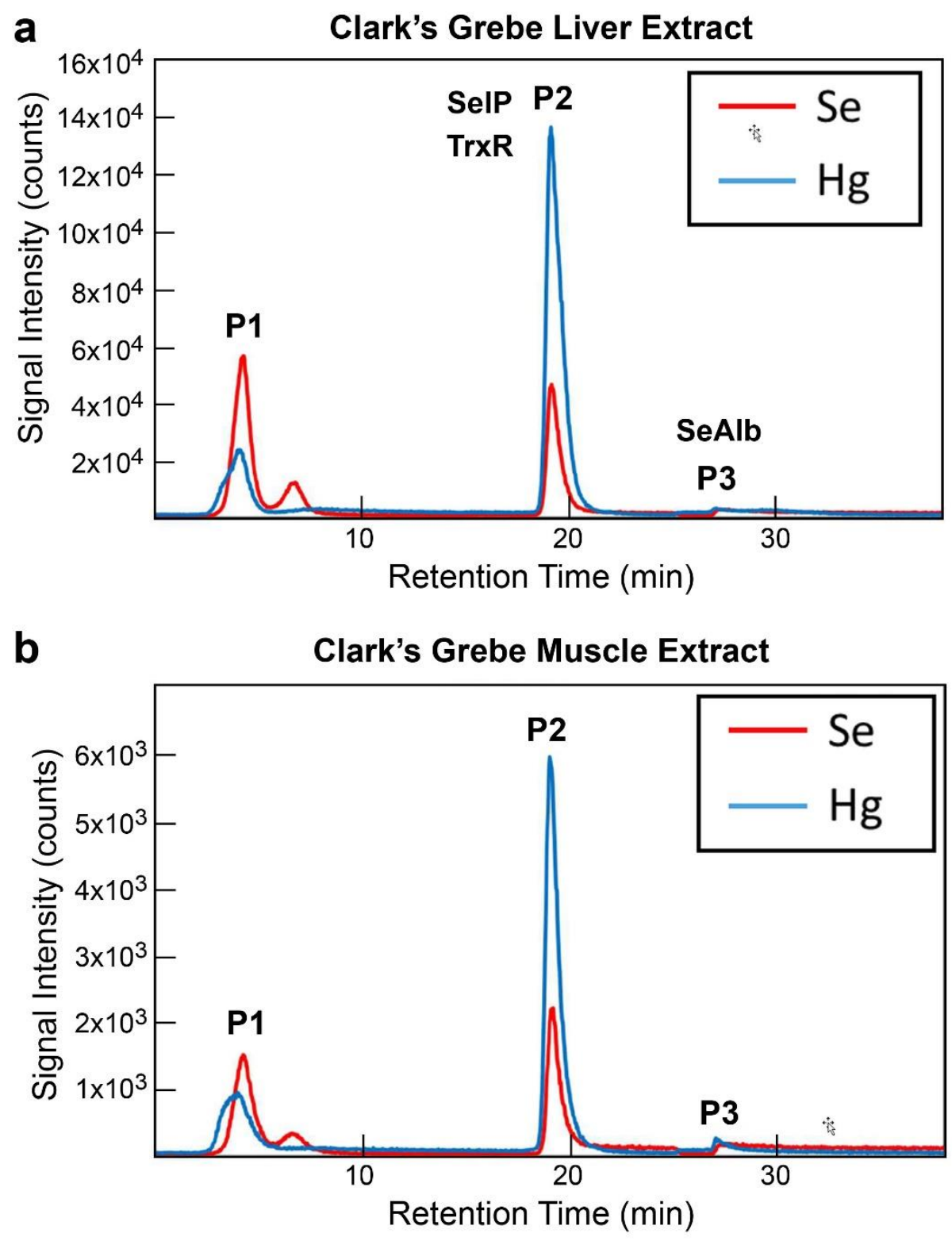

Figure 4 
a SelP protein of zebrafish

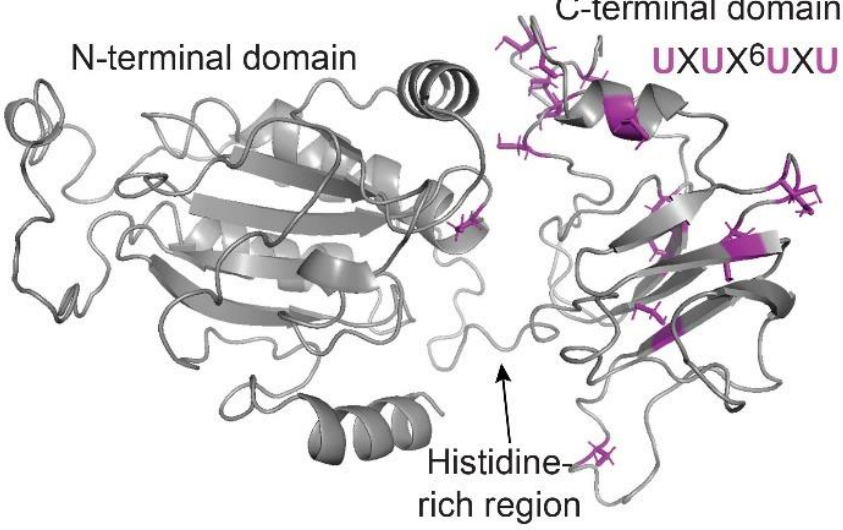

b Great crested grebe DTUQUQEKARNUAUKTN

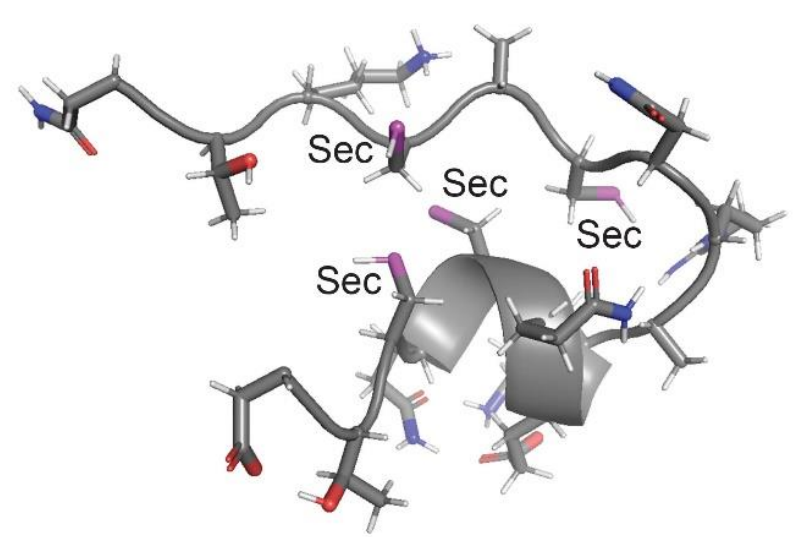

c Zebrafish PTUVUPAGDATUGURKK

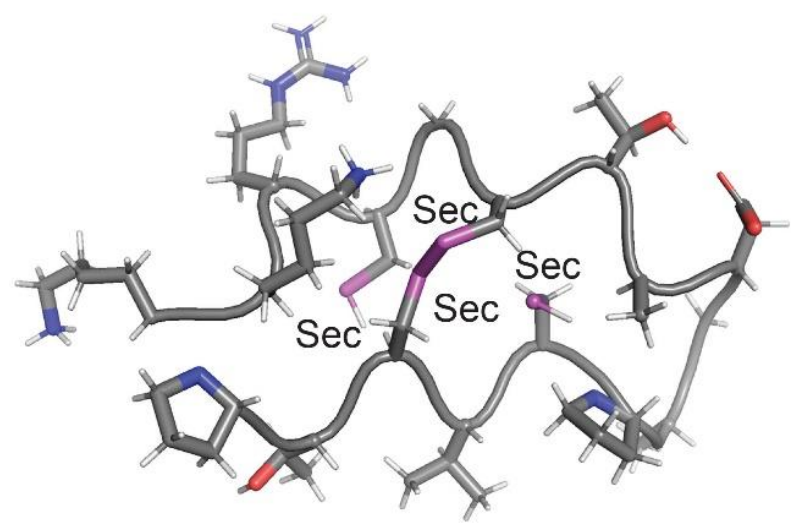

Figure 5 


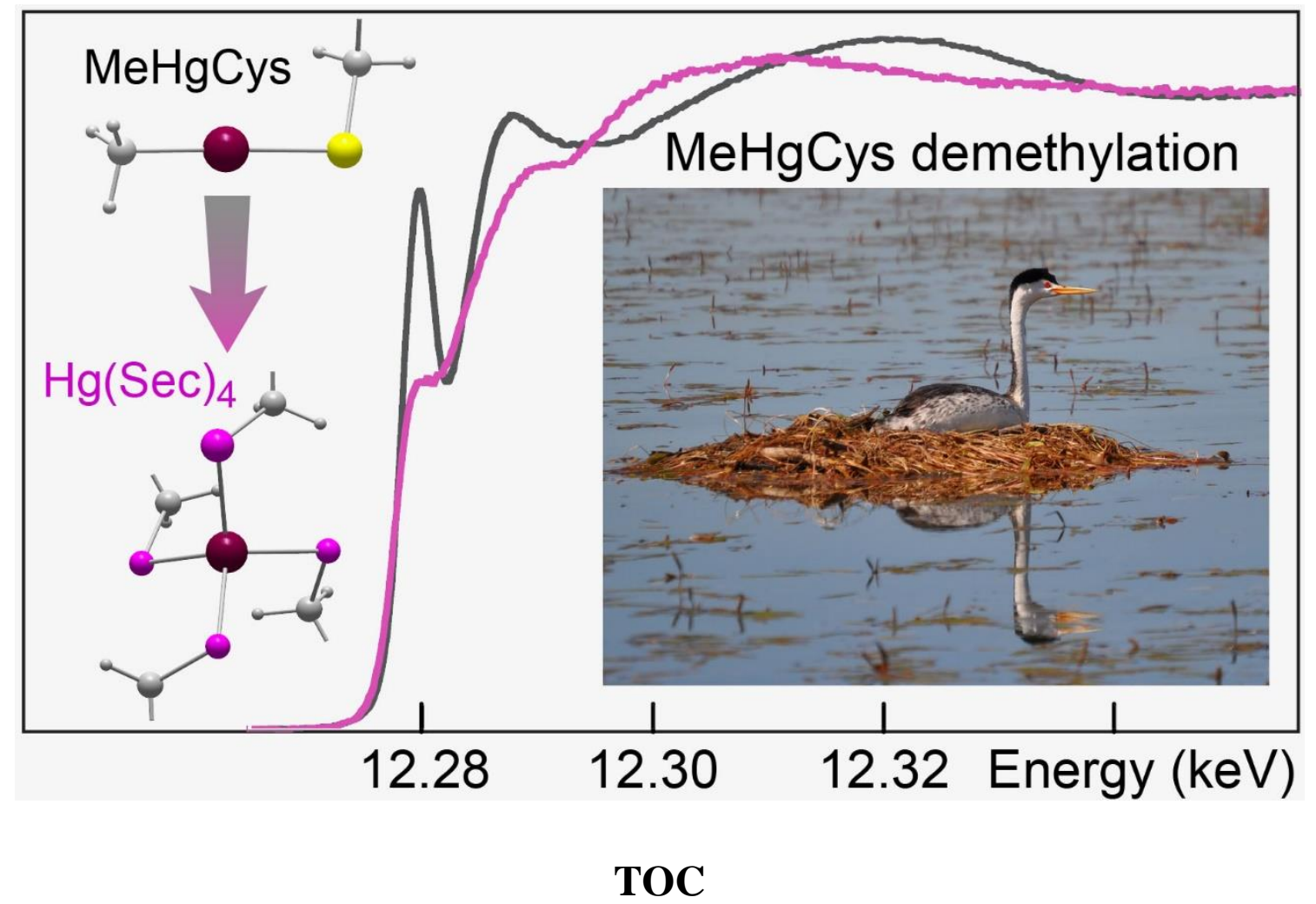




\section{Supplementary Information}

\section{Demethylation of methylmercury in bird, fish, and earthworm}

Alain Manceau ${ }^{1 *}$, Jean-Paul Bourdineaud ${ }^{2}$, Ricardo B. Oliveira ${ }^{3}$, Sandra L.F. Sarrazin ${ }^{3}$, David P. Krabbenhoft $^{4}$, Collin A. Eagles-Smith ${ }^{5}$, Joshua T. Ackerman ${ }^{6}$, A. Robin Stewart ${ }^{7}$, Christian WardDeitrich $^{8}$, M. Estela del Castillo Busto ${ }^{8}$, Heidi Goenaga-Infante ${ }^{8}$, Aude Wack ${ }^{1}$, Marius Retegan ${ }^{9}$, Blanka Detlefs $^{9}$, Pieter Glatzel ${ }^{9}$, Paco Bustamante ${ }^{10}$, Kathryn L. Nagy ${ }^{11} \&$ Brett A. Poulin ${ }^{12,13^{*}}$

1. Université Grenoble Alpes, ISTerre, CNRS, Grenoble, France

2. Université de Bordeaux, Institut Européen de Chimie et Biologie, CNRS, Pessac, France

3. Universidade Federal do Oeste Pará, LabBBEx, Santarém, Pará, Brazil

4. U.S. Geological Survey, Upper Midwest Water Science Center, Middleton, Wisconsin, USA

5. U.S. Geological Survey, Forest and Rangeland Ecosystem Science Center, Corvallis, Oregon, USA

6. U.S. Geological Survey, Western Ecological Research Center, Dixon Field Station, Dixon, California, USA

7. U.S. Geological Survey, Water Resources Mission Area, Menlo Park, California, USA

8. National Measurement Institute, LGC Limited, Teddington, Middlesex, United Kingdom

9. European Synchrotron Radiation Facility (ESRF), Grenoble, France

10. Université La Rochelle, CNRS, Littoral Environnement et Sociétés, La Rochelle, France

11. University of Illinois at Chicago, Department of Earth and Environmental Sciences, Chicago, Illinois, USA

12. U.S. Geological Survey, Water Resources Mission Area, Boulder, Colorado, USA

13. Department of Environmental Toxicology, University of California Davis, Davis, CA 95616, USA

Supporting information includes 17 Figures, 7 Tables and 43 pages.

Data generated during this study are available at https://doi.org/10.5066/P96NP376.

\section{Table of Contents}

S1. Methods

S1.1. Chemical analysis

S1.2. PCR analysis

S1.3. HR-XANES and HR-EXAFS measurement

S1.4. HR-XANES and HR-EXAFS data analysis and accuracy of the fit results

S1.5. Protein extraction and analysis

S.1.6. SelP amino acid sequences

S2. Supplementary figures

S3. Supplementary tables

S4. Supplementary references

S5. Cartesian coordinates of $\mathrm{Hg}(\text { Selenoneine })_{4}$ and $\mathrm{Hg}_{10}(\mathrm{SeMe})_{20}$ 


\section{S1. Methods}

\section{S.1.1. Chemical analysis}

The total Hg concentration of the blood sample of the Clark's grebe was quantified on a wet weight basis $\left(1.70 \pm 0.17 \mathrm{mg} \mathrm{Hg} \mathrm{kg}^{-1}\right.$ wet weight), and converted to a dry weight basis $(7.04 \pm 0.70 \mathrm{mg} \mathrm{Hg}$ $\mathrm{kg}^{-1}$ dry weight) using the average moisture content of grebe blood (75.9\%). ${ }^{1}$ Total $\mathrm{Hg}$ and $\mathrm{MeHg}$ were quantified at the U.S. Geological Survey Mercury Research Laboratory (Middleton, Wisconsin) on tissues on a dry weight basis. Tissues were processed using a nitric acid (4.5 M) extraction and heated at $55{ }^{\circ} \mathrm{C}$ for 8 hours. First, $\mathrm{MeHg}$ was quantified on an aliquot of extracts by aqueous phase ethylation, trapping on Tenax ${ }^{\circledR}$ (Buchem B.V.), isothermal gas chromatography separation, and cold vapor atomic fluorescence spectroscopy (CVAFS) detection using a Brooks Rand MERX-M following U.S. Environmental Protection Agency Method 1630. Second, tissue extracts were further oxidized with sodium persulfate ( $2 \%$ of final volume) overnight and brominated to a final volume of $10 \%$ bromine monochloride $(\mathrm{BrCl})$. Oxidized extracts were measured for total $\mathrm{Hg}$ via stannous chloride reduction and gold amalgamation coupled to CVAFS detection using a Brooks Rand MERX-T following U.S. Environmental Protection Agency Method 1631. The standard deviation between digestion triplicates for $\mathrm{MeHg}$ was $\leq 5.2 \%$ ( $n=3)$, the recovery of MeHg from IAEA-436 reference $(n=9$; certified at 0.200 $\pm 0.010 \mathrm{mg} \mathrm{MeHg} \mathrm{kg}{ }^{-1} \mathrm{dry}$ weight) averaged $92 \%$, and the recovery of MeHg from quality control spikes averaged 99\% ( $n=17)$. The standard deviation between digestion triplicates for total $\mathrm{Hg}$ was $\leq$ 8.6\% ( $n=4)$, the recovery of $\mathrm{Hg}$ from IAEA-436 reference $\left(n=9\right.$; certified at $0.220 \pm 0.010 \mathrm{mg} \mathrm{Hg} \mathrm{kg}^{-}$ ${ }^{1}$ dry weight) averaged $98 \%$, and the recovery of $\mathrm{Hg}$ from quality control spikes averaged $99 \%(n=14)$. The total error in percent $\mathrm{MeHg}(\% \mathrm{MeHg})$ by chemical analysis was estimated by propagation of uncertainty associated with $\mathrm{MeHg}$ and total $\mathrm{Hg}$ concentrations (assigned at $10 \%$ for each measurement).

Total $\mathrm{Hg}$ was quantified on the $<2 \mathrm{~mm}$ soil fraction (Site S1 and S2) using a DMA-80 Hg analyzer (Milestone Dual-cell). The detection limit was $0.003 \mathrm{ng} \mathrm{Hg}$ and accuracy was confirmed by analysis of the IAEA-436 reference from the International Atomic Energy Agency. The established value is $4.19 \pm 0.36 \mathrm{mg} \mathrm{kg}^{-1}$ dry weight and the determined value was $3.96 \pm 0.13 \mathrm{mg} \mathrm{Hg} \mathrm{kg}^{-1}$ dry weight $(n=$ 30).

Selenium concentrations were determined on all samples by isotope dilution-hydride generationinductively coupled plasma-mass spectrometry (ID-HG-ICP-MS) ${ }^{2,3}$ at the U.S. Geological Survey (Menlo Park, California), and on three tissues from the Clark's grebe also at University of La Rochelle (muscle, kidneys, liver). At the U.S. Geological Survey, quality assurance and quality control were 
assessed by procedural blanks (run in triplicate), duplicate digestions $(n=10)$, and certified reference materials that spanned a range of sample matrices (run in triplicate with each run). Se recoveries for certified reference materials averaged $106 \%(n=6)$ for National Institute of Science and Technology (NIST2976) mussel tissue, 102\% $(n=6)$ for National Research Council Canada (NRCC) dogfish muscle (DORM2), 96\% $(n=6)$ for NRCC dogfish liver (DOLT3), 93\% $(n=3)$ for NRCC lobster hepatopancreas (TORT3), and 115\% $(n=3)$ for NRCC marine sediment (MESS-3). At the University of La Rochelle, tissues were digested in duplicate (Clark's grebe muscle and kidneys) and triplicate (Clark's grebe liver) in ultrapure $\mathrm{HNO}_{3}$ in polytetrafluoroethylene reactors with a MARS-6 microwave. Sample digests were analyzed with an Agilent 7500cx ICP-MS with Octopole Reaction System. Certified reference materials included European Reference Material ERM-CE278k mussel tissue (recovery of $108 \%, n=1$ ) and NRCC dogfish liver (DOLT5) (recovery of $101 \% ; n=1$ ). Analytical calibration blanks quantifying instrument noise and procedural blanks were subtracted from sample concentrations. Procedural blanks were always less than $10 \%$ of sample concentrations and averaged $0.010 \mathrm{mg} \mathrm{kg}^{-1}$ dry weight (based on an average sample mass of $10 \mathrm{mg}$ ) and precision for samples run in duplicate averaged $3.0 \%$ (calculated as the absolute deviation divided by the mean, as a percent). Average Se concentrations are reported on Clark's grebe tissues when data from both laboratories is available. The uncertainty in Se concentrations was assigned at $10 \%$ for all measurements, the maximum deviation in recovery of certified reference materials.

Molar ratios of $\mathrm{Se}$ to $\mathrm{Hg}$ were calculated using total $\mathrm{Se}$ concentration and (1) the total $\mathrm{Hg}$ concentration ( $\mathrm{Se}: \mathrm{Hg}_{\text {tot }}$ ) and (2) the $\mathrm{Hg}$ concentration as $\mathrm{Hg}(\mathrm{Sec})_{4}\left(\mathrm{Se}: \mathrm{Hg}(\mathrm{Sec})_{4}\right)$. The latter was calculated by multiplying the percentage of $\mathrm{Hg}$ as $\mathrm{Hg}(\mathrm{Sec})_{4}$ as determined by HR-XANES by the total $\mathrm{Hg}$ concentration, and therefore is only reported for tissues where $\mathrm{Hg}(\mathrm{Sec})_{4}$ was quantified. The total error in $\mathrm{Se}: \mathrm{Hg}_{\text {tot }}$ and $\mathrm{Se}: \mathrm{Hg}(\mathrm{Sec})_{4}$ values was estimated by propagation of uncertainty associated with $\mathrm{Se}$ and total $\mathrm{Hg}$ concentrations and HR-XANES spectral fits.Figure S8 presents the $\mathrm{Se}: \mathrm{Hg}_{\text {tot }}$ and $\mathrm{Se}: \mathrm{Hg}(\mathrm{Sec})_{4}$ of the bird, fish, and earthworm tissues as a function of the total $\mathrm{Hg}$ concentration. Horizontal dashed lines present stoichiometric ratios of 4 (red) and 1 (gray) for reference of ratios of $\mathrm{Hg}(\mathrm{Sec})_{4}$ and HeSe species, respectively. Stoichiometric ratios of $\mathrm{Se}: \mathrm{Hg}_{\text {tot }}$ less than 1 are observed in the feather and muscle of the Clark's grebe and several muscle tissues of fish (Plagioscion squamosissimus and Cichla sp., $n=4$ ) (Figure S8a). These samples either had no detectable $\mathrm{Hg}(\mathrm{Sec})_{4}$ (Clark's grebe feather, fish muscle tissues) or $\mathrm{Hg}(\mathrm{Sec})_{4}$ was a minor species (Clark's grebe muscle, 11 $\left.\pm 5 \% \mathrm{Hg}(\mathrm{Sec})_{4}\right)$. All other tissues $(n=22)$ exhibited Se:Hgtot greater than 1 . Of the tissues where $\mathrm{Hg}(\mathrm{Sec})_{4}$ was quantified, the $\mathrm{Se}: \mathrm{Hg}(\mathrm{Sec})_{4}$ was greater than 4 in all samples aside from the Clark's 
grebe kidneys $\left(\mathrm{Se}: \mathrm{Hg}(\mathrm{Sec})_{4}=2.1 \pm 0.3\right)$ and liver tissues $\left(\mathrm{Se}: \mathrm{Hg}(\mathrm{Sec})_{4}=1.3 \pm 0.2\right)$ (Figure S8b). We attribute the $\mathrm{Se}: \mathrm{Hg}(\mathrm{Sec})_{4}$ less than 4 in these two tissues to the presence of $\mathrm{Hg}_{\mathrm{x}}(\mathrm{Se}, \mathrm{Sec})_{\mathrm{y}}$ clusters/nanoparticulate $\mathrm{Hg}$ selenide, as detected in the HR-EXAFS spectra of the Clark's grebe liver (Figure S9). The inverse relationship between $\mathrm{Se}: \mathrm{Hg}(\mathrm{Sec})_{4}$ and total $\mathrm{Hg}$ concentration (Figure S8b) may reflect a continuum in $\mathrm{Hg}$ speciation from $\mathrm{Hg}(\mathrm{Sec})_{4}$ at low total $\mathrm{Hg}$ concentration to $\mathrm{Hg}_{\mathrm{x}}(\mathrm{Se}, \mathrm{Sec})_{\mathrm{y}}$ clusters at high total $\mathrm{Hg}$ concentration across the various tissues, but further work is ultimately needed to resolve the biochemical reasons for these observations.

\section{S.1.2. PCR analysis}

DNA extraction from soil and earthworm microflora. For the soil sample (site S2), the DNeasy PowerSoil kit (Qiagen, Product 12888) was used to extract bacterial genomic DNA from $0.25 \mathrm{~g}$ of soil following the manufacturer's recommendations. For earthworms, individual earthworms were isolated in a plastic box devoid of soil for $24 \mathrm{~h}$ and then dissected and the digestive tract opened. With a sterile spatula, the interior of the digestive tract was transferred to a $12 \mathrm{~mL}$ tube containing sterile LB medium. Cultures were incubated static at $16^{\circ} \mathrm{C}$ for $3 \mathrm{~d}$. After centrifugation, genomic DNA was extracted from the bacterial pellet with a solution of EDTA, Tris, and lysozyme, followed by proteinase K and Nlaurylsarkosinate. ${ }^{4}$ The genomic DNA was purified by precipitating in $60 \%$ ethanol and rinsing several times in $70 \%$ ethanol. The DNA was rinsed a final time with $70 \%$ ethanol overnight at $-20{ }^{\circ} \mathrm{C}$, air dried, and dissolved in a solution of $10 \mathrm{mM}$ Tris $(\mathrm{pH}$ 8) and $1 \mathrm{mM}$ EDTA. The concentration of DNA was measured at $260 \mathrm{~nm}$.

Amplification of $\boldsymbol{h g c A}$ gene fragments from environmental samples. The $h g c A$ gene fragments were amplified from environmental DNA samples using a combination of a forward primer (hgcA-F) targeting the highly conserved putative cap helix motif and a reverse primer (hgcA-912R) targeting a motif between the third and fourth predicted transmembrane helices near the C-terminus ${ }^{5}$ (Table S6). These two primers allow the amplification of a product from the hgcaA gene around 650 base pairs (bp). ${ }^{6}$ The control amplification of an $h g c A$ gene fragment (650 bp) from a plasmid containing $h g c A$ was confirmed using hgcA-F and hgcA-912R primers and DreamTaq polymerase reagent (Figure S11a); the $h g c A$ gene fragment was provided by Hee-Sung Bae (University of Florida). Upon receipt, the plasmid was extracted and purified after alkaline lysis on columns containing a silica membrane (kit NucleoSpin plasmid, Macherey-Nagel, Product 740588.250).

The PCR amplification of environmental samples was performed using identical cycling conditions

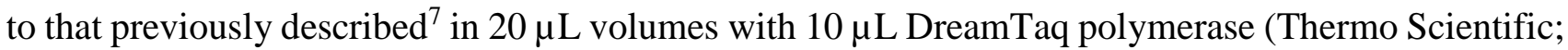


Products K1071), $0.2 \mathrm{mM}$ of dNTP, $0.75 \mu \mathrm{M}$ of each primer, and the indicated amount of plasmid or genomic DNA. The final concentration of $\mathrm{MgCl}_{2}$ was $1.5 \mathrm{mM}$. Amplification products were verified by gel electrophoresis on a 1\% agarose gel. PCR products between approximately 620-660 bp were excised from the gel and purified on a column containing a silica membrane (kit NucleoSpin Gel and PCR Clean-up, Macherey-Nagel, Product 740609.250). The isolated PCR products were ligated into pGEM T-Easy vector (Promega) overnight at $4{ }^{\circ} \mathrm{C}$ according to manufacturer's recommendations. Thereafter, E. coli TOP10 cells (Invitrogen Thermo Fisher Scientific, Product C404010), rendered chemically competent for transformation through $\mathrm{CaCl}_{2}$ treatment, were transformed with $2 \mu \mathrm{L}$ of the ligation mixture. Transformants were selected on ampicillin-containing jellified LB medium (50 $\mu \mathrm{g} / \mathrm{mL})$. Positive recombinants were selected using PCR: 10 colonies were picked out from the Petri dish and each was suspended in a mixture made of $10 \mu \mathrm{L}$ of sterile milliQ water, $0.5 \mu \mathrm{L}(50 \mathrm{ng}) \mathrm{of}$ M13 forward primer, $0.5 \mu \mathrm{L}(50 \mathrm{ng})$ of M13 reverse primer, and $12.5 \mu \mathrm{L}$ of 2 x concentrated DreamTaq blend. The thermocycling program was as follows: initial denaturation step at $94{ }^{\circ} \mathrm{C}$ for $10 \mathrm{~min}, 36$ cycles at $94{ }^{\circ} \mathrm{C}$ for $60 \mathrm{~s}, 55^{\circ} \mathrm{C}$ for $60 \mathrm{~s}$, and $72{ }^{\circ} \mathrm{C}$ for $140 \mathrm{~s}$, followed by a final extension step at 72 ${ }^{\circ} \mathrm{C}$ for $10 \mathrm{~min}$. Positive transformants were cultured on LB medium containing ampicillin $(50 \mu \mathrm{g} / \mathrm{mL})$ and the harbored plasmids were purified using the kit NucleoSpin plasmid (Macherey-Nagel, Product 740588.250). The fragment contained in two recombinant plasmids was sequenced using M13 forward and reverse primers (GATC Biotech, Eurofins Genomics Company).

PCR results. Soil from site $\mathrm{S} 2$ contained bacterial DNA with the $h g c A$ gene with an amplified gene fragment length of approximately $630 \mathrm{bp}$ (Figure S11b, lane 3). After purification of total genomic DNA from earthworm microflora, amplified $h g c A$ gene fragments of approximately 630 to $650 \mathrm{bp}$ were identified for earthworms from sites S1 and S2 (Figure S11c). At site S1, the hgcA fragments were from anecic earthworm microflora (Figure S11c, panel i, lane 3), and at site S2 they were from both anecic and endogeic earthworm microflora (Figure S11c, panel ii, lanes 3 and 4, respectively).

Only a single $h g c A$ sequence was retrieved from the excised and purified bands from both the soil and earthworm microflora samples. The retrieved $h g c A$ sequence (633 nucleotides, 211 amino acid residues; Figure S12a) matches $h g c A$ sequences belonging to the Geobacter genus. Since earthworms ingest soil, the $h g c A$ gene-harboring bacteria detected in the gut microflora of earthworms are interpreted to have originated in the soil. At the nucleotide level, the retrieved $h g c A$ sequence best matched the hgcA sequence of Geobacteraceae clone B2_FE06 (Figure S12b), which was amplified from the total bacterial genomic DNA of a temperate forested wetland in southern Sweden. ${ }^{6}$ The retrieved $h g c A$ sequence contained 437 of 633 identical nucleotides to that of Geobacteraceae clone 
B2_FE06 (identity percentage of 69\%). At the protein level, the amino acid sequence of the retrieved hgcA gene best matched a sequence of Geobacteraceae isolated from paddy soil in the Guizhou province of southwest $\mathrm{China}^{8}$; 43 of 211 amino acid residues are identical (identity percentage of $68 \%$; Figure S12c).

\section{S.1.3. HR-XANES and HR-EXAFS measurement}

Freeze-drying a frozen tissue does not change the speciation of chemically-bound metals, ${ }^{9}$ which we verified previously on MeHgCys. ${ }^{10}$ All freeze-dried samples were pressed into $5.0 \mathrm{~mm}$ diameter and $2.5 \mathrm{~mm}$ thick pellets, mounted in a polyether ether ketone (PEEK) sample holder sealed with Kapton tape, and maintained in a desiccator until their transfer into the liquid helium cryostat of the beamline. Mercury L ${ }_{3}$-edge HR-XANES and HR-EXAFS spectra were measured with high-reflectivity analyzer crystals $^{11}$ on beamline ID26 at the European Synchrotron Radiation Facility (ESRF). The storage ring was operated in the 7/8 + 1 filling mode, with $200 \mathrm{~mA}$ current. Rejection of higher harmonics and reduction of heat load were achieved with a white beam Pd-coated, flat mirror working under total reflection at $2.5 \mathrm{mrad}$ deflecting angle. The energy of the incoming beam was selected by the 111 reflection of a Si double crystal monochromator, and the beam was focused horizontally by a second Pd-coated mirror and vertically by a third Pd-coated mirror. The flux on the sample was approximately $10^{13}$ photon/s in a beam footprint of $\sim 700(\mathrm{H}) \times 80(\mathrm{~V}) \mu \mathrm{m}^{2}$ full width at half maximum (FWHM). The

$\mathrm{Hg} \mathrm{L}_{\alpha 1}\left(3 \mathrm{~d}_{5 / 2} \rightarrow 2 \mathrm{p}_{3 / 2}\right)$ fluorescence line was selected using the 555 reflection of five spherically bent $($ radius $=0.5 \mathrm{~m}){ }^{11} \mathrm{Si}$ analyzer crystals $($ diameter $=100 \mathrm{~mm})$ aligned at $81.8^{\circ}$ Bragg angle in a vertical Rowland geometry. The diffracted intensity was measured with a Si drift diode detector (SDD) in single photon counting mode. The effective energy resolution, obtained by convoluting the total instrument energy bandwidth (spreads of the incident and emitted rays) and the $3 \mathrm{~d}_{5 / 2}$ core-hole width from the $\mathrm{L}_{\alpha 1}$ line was about $3.0 \mathrm{eV}$, compared to an intrinsic line broadening of about $6.1 \mathrm{eV}$ in conventional fluorescence yield measurement with a solid-state detector (conventional XANES and EXAFS).

The incident energy was scanned from $12260 \mathrm{eV}$ to $12360 \mathrm{eV}$ in $0.2 \mathrm{eV}$ steps in HR-XANES mode, and the spectra were normalized to unity at $\mathrm{E}=12360 \mathrm{eV}$. The incident energy was scanned from $12210 \mathrm{eV}$ to $13050 \mathrm{eV}$ in $2.0 \mathrm{eV}$ steps in HR-EXAFS mode. The stability in energy of the incident beam was monitored by measuring frequently a fresh MeHgCys reference. The photon energy is referenced to the maximum of the near-edge peak of MeHgCys at $12279.8 \mathrm{eV}$. The precision of the calibrated spectra is $0.1 \mathrm{eV}$. Spectra were collected at a temperature of $10-15 \mathrm{~K}$ and a scan time of 15 
$\mathrm{s}$ to reduce exposure, and repeated at different pristine positions on the sample to increase the signalto-noise ratio. Radiation damage, which occurs when the beam is positioned on the same spot for too long, depends on the chemical form of $\mathrm{Hg}$ and, for a given form, varies with the kinetic energy of the photoelectron (i.e., energy of the incident beam). Bound states, probed at low kinetic energy, are more sensitive to radiation exposure than unbound states in the continuum. This dependence is illustrated in Figure $\mathrm{S} 17$ with $\mathrm{MeHgCys}$, which is the most radiation sensitive $\mathrm{Hg}$ species. $\mathrm{Hg}(\mathrm{SR})_{2}$ is more stable, and nanoparticulate $\beta-\mathrm{HgS}$ and $\mathrm{HgSe}$ resist damage during long exposure time.

\section{S.1.4. HR-XANES and HR-EXAFS data analysis and accuracy of the fit results}

The number of $\mathrm{Hg}$ species was determined by principal component analysis, ${ }^{12,13}$ and their nature subsequently by iterative transformation factor analysis $\left(\mathrm{ITFA}^{14}\right)$ for the $\mathrm{Hg}(\mathrm{Sec})_{4}$ species, and by target transformation analysis ${ }^{15}$ for the MeHgCys and $\mathrm{Hg}(\mathrm{SR})_{2}$ species. Target transformation analysis was conducted with reference spectra from a large dataset of $\mathrm{Hg}$ minerals $\left(\alpha-\mathrm{HgS}, \beta-\mathrm{HgS}, \beta-\mathrm{HgS} \mathrm{NP}_{\text {, }}\right.$ $\mathrm{HgSe}, \mathrm{HgSe}$ NP), and $\mathrm{Hg}(\mathrm{II})$ and $\mathrm{MeHg}$ model complexes described previously (Ref. ${ }^{10}$ and references therein). All reference spectra were considered as a basis for identification, but only diagnostic spectra are discussed in the article. The proportions of the $\mathrm{Hg}$ species were evaluated using least-squares fitting (LSF) of the data with linear combinations of the Clark's grebe breast feather spectrum, the $\mathrm{Hg}(\mathrm{Sec})_{4}$ spectrum, and the spectrum of the $\mathrm{Hg}(\mathrm{L}-\text { glutathione })_{2}$ complex $\left(\mathrm{Hg}(\mathrm{GSH})_{2}\right)$ at $\mathrm{pH} \mathrm{7.4.}{ }^{16,}{ }^{17} \mathrm{In}$ $\mathrm{Hg}(\mathrm{GSH})_{2}, \mathrm{Hg}(\mathrm{II})$ is bonded approximately linearly to the cysteinyl sulfur atoms at $2.33 \AA$ from the two $\gamma$-Glu-Cys-Gly peptides and surrounded in trans-equatorial position by a carboxyl oxygen from a Gly residue at $2.62 \AA$, the backbone carbonyl oxygen at $2.88 \AA$ from the Gly-Cys peptide bond (Gly-NH-CO-Cys) of the same GSH molecule, and an amide group (-NH) at $3.01 \AA$ from the second GSH molecule. ${ }^{18}$ This reference is a good proxy for the $\mathrm{Hg}(\mathrm{SR})_{2}$ coordination in biota. ${ }^{18}$ The precision of estimation of a fit component was estimated to be equal to the variation of its value when the fit residual (NSS) was increased by $20 \%$. NSS is the normalized sum-squared difference between two spectra expressed as $\Sigma\left[\left(\mathrm{y}_{2}-\mathrm{y}_{1}\right)^{2}\right] / \Sigma\left(\mathrm{y}_{2}{ }^{2}\right)$. The principal component analysis (PCA) and linear fit programs from beamline 10.3.2 at the Advanced Light Source were used. ${ }^{12,19}$

The accuracy of spectral fit results was evaluated by comparing the percentage and concentration of $\mathrm{MeHg}$ obtained by chemical analysis and HR-XANES. The relative abundance of $\mathrm{MeHg}$ as determined by HR-XANES (\%MeHgCysXANES) and chemical analysis (\% MeHg Chem) show good agreement between the two independent methods (Figure S4a), demonstrating a high level of accuracy in spectral fit results. In Figure S4a, a generic Y-axis error bar represent the precision of HR-XANES 
spectral fits and the $\mathrm{X}$-axis error bar represent the total propagation of error in $\% \mathrm{MeHg}_{\mathrm{Chem}}$ measurements. Across the tissues a moderately lower percent $\mathrm{MeHg}$ was observed by chemical analysis compared to HR-XANES. We attribute this discrepancy primarily to the lower recovery of $\mathrm{MeHg}$ in tissue digests during the ethylation step of the analysis (average of $92 \% \mathrm{MeHg}$ recovery for IAEA-436, $n=9$ ). In contrast, HR-XANES analysis does not require sample modification prior to measurement, is sensitive to all $\mathrm{Hg}$ atoms in a tissue sample, $\mathrm{MeHgCys}$ has a distinctive spectral signature with an intense near-edge peak, and the percentage $\mathrm{MeHgCys}$ is obtained directly from a spectral fit. To assess the uncertainty of estimation further, the concentrations of $\mathrm{MeHg}$ determined by HR-XANES $\left([\mathrm{MeHgCys}]_{\mathrm{XANES}}=\% \mathrm{MeHgCys} \mathrm{x}[\mathrm{Hg}]_{\mathrm{Tot}}\right)$ and chemical analysis $\left([\mathrm{MeHg}]_{\mathrm{Chem}}\right)$ were compared (Figure S4b and Table S7). Good agreement was observed between [MeHgCys]XANES and

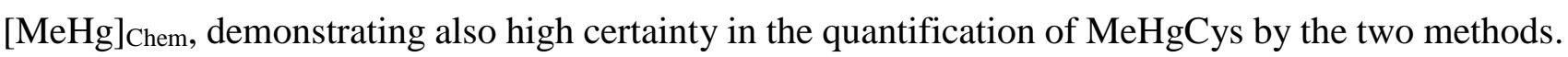

The HR-EXAFS spectrum from the Clark's grebe liver was analyzed with WinXAS ${ }^{20}$ using amplitude and phase shift functions generated by FEFF 7.0.2 $2^{21}$ and HgSe as structure model ${ }^{22}$ (Table $\mathrm{S} 4)$. The amplitude reduction factor $\mathrm{S}_{0}^{2}$ was fixed to 0.9 . EXAFS lacks sensitivity to the $\mathrm{C}$ atom at about $2.07 \AA$ from the methyl group of MeHgCys and misses $\mathrm{Hg}$ atoms at about $4.46 \AA$ as a result of the high disorder of the $\mathrm{Hg}_{\mathrm{x}}(\mathrm{Se}, \mathrm{Sec})_{\mathrm{y}}$ clusters. Thus, the coordination number $(C N)$ of $\mathrm{Hg}$ at $4.46 \AA$ is an apparent number.

\section{S.1.5. Protein extraction and analysis}

Protein extraction from Clark's grebe tissues. To assess if $\mathrm{Hg}$ and $\mathrm{Se}$ were associated with SelP, a protein extraction was performed on the Clark's grebe liver and muscle tissues. ${ }^{23}$ In triplicate, $0.1 \mathrm{~g}$ of lyophilized, homogenized tissue was mixed with $0.4 \mathrm{~g}$ of protein extraction buffer $(50 \mathrm{mM}$ TRIS-HCl, CAS 1185-53-1; 0.01 g/g SigmaFast Protease Inhibitor Cocktail, Sigma Aldrich) in 1.5 mL Eppendorf tubes. Procedural extraction blanks were performed in triplicate. At $4{ }^{\circ} \mathrm{C}$, samples were homogenized (Omni Tissue Homogenizer with plastic disposable tips) using 5 repeated cycles of a 10 second homogenization and 50 second pause. Protein extracts were separated from residual tissues by centrifugation at $10,000 \mathrm{~g}$ at $4{ }^{\circ} \mathrm{C}$ for 30 minutes. The supernatant was immediate frozen at $-80{ }^{\circ} \mathrm{C}$ and shipped at $-80{ }^{\circ} \mathrm{C}$ to LGC Group (Teddington, United Kingdom) for selenoprotein analysis.

Speciation of Hg and Se in Clark's grebe tissues. Protein extracts from Clark's grebe liver tissue $(n$ $=3$ ) and muscle tissue $(n=3)$ and extraction blanks $(n=3)$ were screened for the co-elution of $\mathrm{Hg}$ and Se with selenoproteins by double affinity (AF) high performance liquid chromatography-inductively coupled plasma mass spectrometry (HPLC-ICPMS ${ }^{3,24}$ ). All samples were measured in parallel in the 
same analytical run. Each sample was measured in duplicate. The double AF-HPLC chromatographic system achieves separation of three major Se protein species by the combination of two AF columns (HiTrap Heparin High Performance, 1mL; Hi Trap Blue High Performance, $1 \mathrm{~mL}$ ) that retain SelP and SeAlb, respectively. Peak 1 elutes forms of Se not retained on the columns, including glutathione peroxidase 3 (GPX3), inorganic Se species, and LMW Se species (retention time of approximately 3.3 minutes). Peak 2 elutes at the retention time of SelP (approximately 19.3 minutes), known to have high affinity to heparin. Peak 3 elutes at the retention time of Se-albumin (Se-Alb; approximately 28.0 minutes). The plasma reference material NIST SRM 1950 was used as the quality control material for chromatographic quality assessment (Se species elution distribution and order), because of the lack of any certified material for Se-species in tissue. It should be noted that thioredoxin reductase (TrxR) elutes at the same retention time as SelP, based on the analysis of a protein standard of TrxR from rat liver. Se species were eluted using ammonium acetate buffers $\left(0.05\right.$ and $\left.1.5 \mathrm{M}, \mathrm{pH} 7,0.5 \mathrm{~mL} \mathrm{~min}^{-1}\right)$. Eluent from the AF-HPLC was introduced to a collision cell ICP-MS/MS for measurement of Se and Hg (8800 ICP-QQQMS, Agilent Technologies, UK). The ICP-MS/MS was operated in oxygen mode, and therefore Se was determined by measurement of ${ }^{80} \mathrm{Se}$ as ${ }^{96} \mathrm{SeO}$. Mercury was measured by monitoring ${ }^{202} \mathrm{Hg}$. Relative elemental percentages were calculated using the peak area distribution of Peaks 1-3. Hg mass balance of tissue extracts associated with Se species was not performed.

Good repeatability in $\mathrm{Hg}$ and Se chromatograms of triplicate tissue extracts was observed. An example of $\mathrm{Hg}$ and Se chromatograms of the Grebe liver and muscle extracts are presented in Figure 4. In the liver and muscle tissues, the majority of detected Hg co-eluted with Peak 2 (SelP + TrxR; $87.8 \pm 0.4 \%$ and $84.3 \pm 0.7 \%$, respectively), and the remainder of $\mathrm{Hg}$ co-eluted with Peak 1 (GPX3, inorganic Se species, LMW Se species; $11.5 \pm 0.4 \%$ and $13.7 \pm 0.6 \%$ respectively). Similarly, Se chromatograms show that Se co-eluted with Peak $1(71.4 \pm 0.7 \%$ and $62.5 \pm 2.4 \%$ in liver and muscle tissue extracts, respectively) and Peak 2 (27.3 $\pm 0.8 \%$ and $35.5 \pm 2.3 \%$, respectively). No considerable $\mathrm{Hg}$ or Se in either tissue extract was observed to co-elute with Peak 3 (Se-Alb; $\leq 2 \%$ ). The Se and $\mathrm{Hg}$ chromatograms of extraction blanks contained only minor peaks for $\mathrm{Hg}$ also observed in the eluent blank (signal $\leq 3 \%$ of tissue extracts), confirming that $\mathrm{Hg}$ and Se chromatograms of tissue extracts were free of contamination. In summary, this speciation analysis shows that $\mathrm{Hg}$ co-elutes primarily with SelP and TrxR and minorly with GPX3 in Grebe liver and muscle tissues, where HR-XANES quantified $86 \%$ and $11 \%$ of $\mathrm{Hg}$ as $\mathrm{Hg}(\mathrm{Sec})_{4}$ (Table S5). Based on biostructural considerations, formation of $\mathrm{Hg}(\mathrm{Sec})_{4}$ is incompatible with TrxR because this homodimeric protein containing a single Sec residue per subunit ${ }^{25}$, therefore binds $\mathrm{Hg}$ linearly. ${ }^{26}$ Similarly, the minor elution of $\mathrm{Hg}$ with Peak 
1 is considered unlikely to be a result of $\mathrm{Hg}$ association with GPX3, given that GPX3 is a tetramer containing one Sec residue in each subunit ${ }^{27}$ too far apart to form a $\mathrm{Hg}(\mathrm{Sec})_{4}$ complex. In addition, the HR-XANES spectra of $\mathrm{MeHgSec}$ and $\mathrm{Hg}(\mathrm{Sec})_{2}$ species are clearly distinguished from $\mathrm{MeHgCys}$ and $\mathrm{Hg}(\mathrm{GSH})_{2}$ (Figure S2c, d), further supporting that co-elution of $\mathrm{Hg}$ and Se with Peak 2 is likely as $\mathrm{Hg}(\mathrm{Sec})_{4}$.

\section{S.1.6. SelP amino acid sequence}

Crested grebe (Podiceps cristatus). The partial protein sequence has been established from GenBank: KL268852.1 by joining two translated nucleotides fragments from locations 15116-15235 and 1613216350. This incomplete sequence is also found under the protein accession number GenBank: KFZ63143.1. The trace of the first nucleotidic fragment is underlined below.

Incomplete SelP protein:

RCGRLVYHLGLPYSFLSFQYVEES IKIAYCENKCGNCSYTEPAIDDICENITKTADEKLAEPEPKPTGQHSHH HNLHRHRHHHHHHHREGSRHSKNENHQNSSETQRHHPHSGHNRHDHTGSHEQVDTVPPGESVEISQDKKLUKK GKTSCKNQLTUNWQTASDSASSSUCCHURHLLFEELGNSVTUQCRGALPNSCRUHGQLSAEDITESUQURLLT AAUQSPAAGASETSDTUQUQEKARNUAUKTN

C-terminal region used to model the $\mathrm{Hg}$-binding site DTUQUQEKARNUAUKTN

Zebrafish (Danio rerio). The SelP sequence has been established from the protein accession number GenBank: NP_840082.3.

SelP protein:

MWKALSLTLALCLLVGCSAESETEGARCKLPPEWKVGDVEPMKNALGQVTVVAYLQASULFCLEQASKLNDLL LKLEKQGYPNIAYMVVNNREERSQRLHHLLQERLLNITLYAQDLSQPDAWQAVNAEKDDILVYDRCGRLTYHL SLPYTILIHPHVEEAIKHTYCDRICGECSLESSAQLEECKKATEEVNKPVEEEPRQDHGHHEQGHHEHQGEAE RHRHGHHHPHHHHHHHRGQQQVDVDQQVLSQVDFGQVAVETPMMKRPUAKHSRUKVQYSUQQGADSPVASUCU HURQLFGGEGNGRVAGLUHCDEPLPASUPUQGLKEQDNH IKETUQURPAPPAEUELSQPTUVUPAGDATUGUR $\mathrm{KK}$

C-terminal region used to model the $\mathrm{Hg}$-binding site PTUVUPAGDATUGURKK

Fish, birds, and mammals. We performed BLAST analyses with known SelP sequences in fish, birds, and mammals as queries to search protein databases for distant SelP homologs. The sequences 
identified served as new search entries for SelP homologs in nucleotide sequence databases. Multiple alignments of SelP sequences (Figure S13) were carried out using the DNAMAN software.

\section{S2. Supplementary figures}

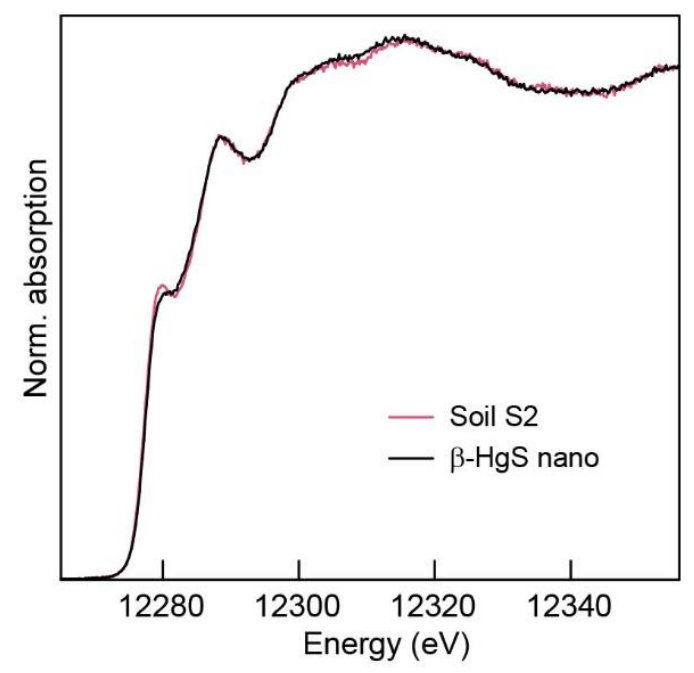

Figure S1. Mercury $\mathrm{L}_{3}$-edge HR-XANES spectra of the $<63 \mu \mathrm{m}$ fraction of soil S2 $\left(27.6 \mathrm{mg} \mathrm{Hg} \mathrm{kg}^{-1}\right.$ $\mathrm{dw})$ and the clay-size fraction $(0.1-2.0 \mu \mathrm{m})$ from the A horizon soil $\left(191 \mathrm{mg} \mathrm{Hg} \mathrm{kg}^{-1} \mathrm{dw}\right)$ studied in Ref. ${ }^{28}$. $\mathrm{Hg}$ is speciated as nanoparticulate $\beta-\mathrm{HgS}$ in the A horizon sample. 

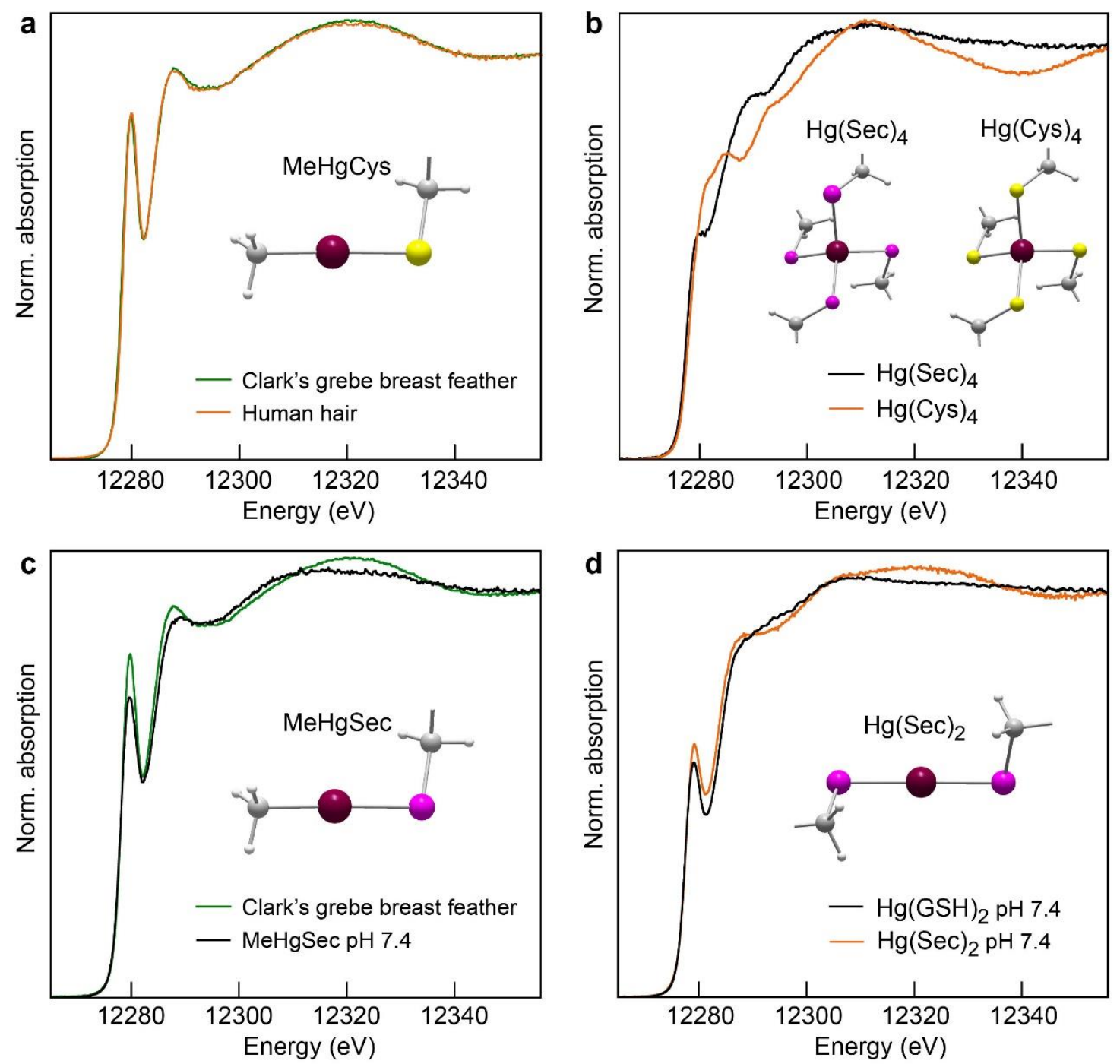

Figure S2. a) HR-XANES spectra of MeHgCys in human hair and Clark's grebe breast feather. The human hair spectrum corresponds to sample $1 \mathrm{MeHg} 13.8([\mathrm{Hg}]=13.8 \mathrm{ppm})$ from Figure 3 of Ref. ${ }^{29}$. b-d) HR-XANES spectra of cysteine and selenocysteine $\mathrm{Hg}$ complexes illustrating the high sensitivity of HR-XANES to the coordination and ligation of $\mathrm{Hg}$. 

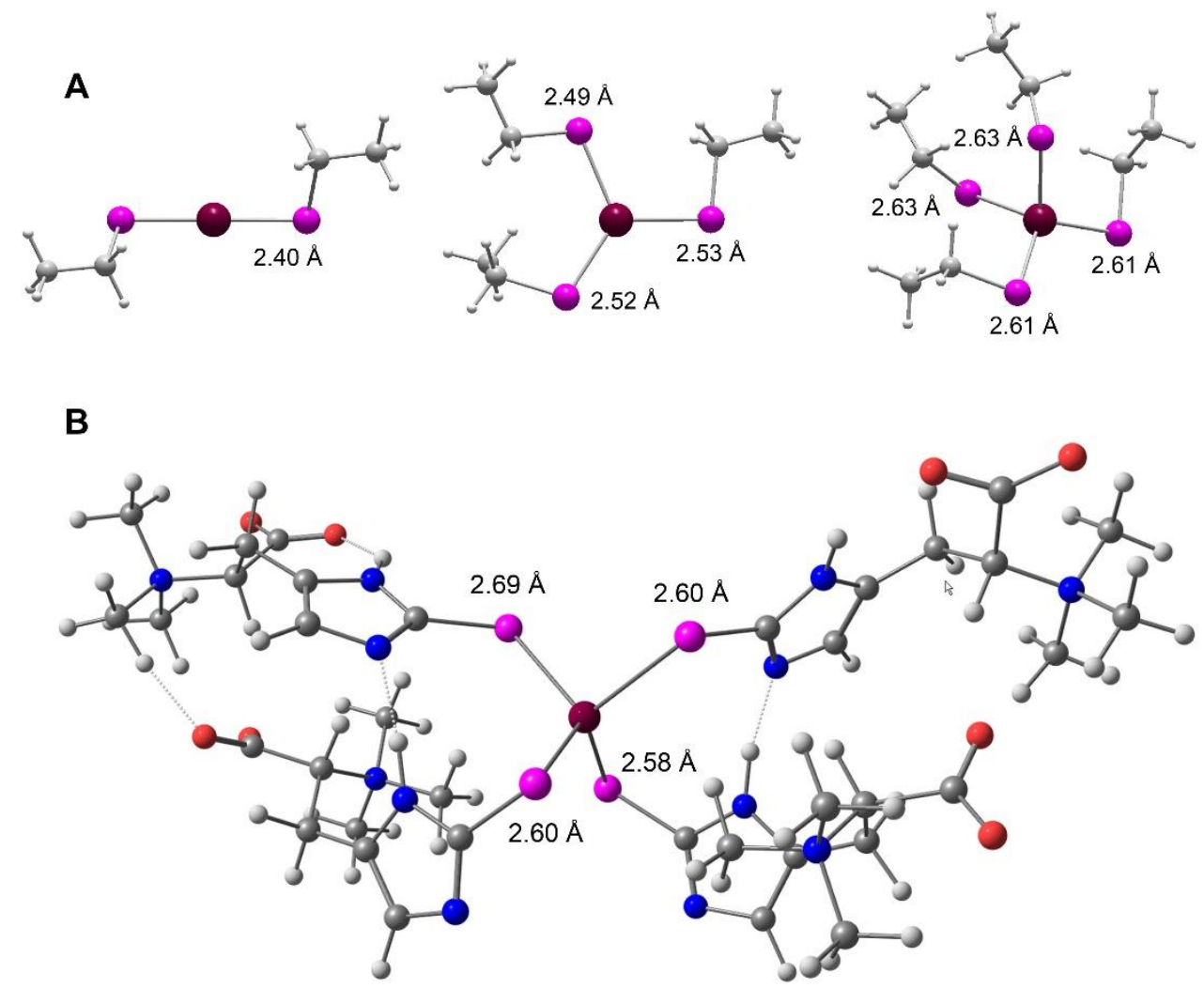

Figure S3. Geometry optimization of the $\mathrm{Hg}$ di-, tri-, and tetraselenolate complexes (modeled with ethylselenol) (a) and $\mathrm{Hg}$ tetraselenoneine complex ( $\mathrm{Hg}$ (selenoneine) $\left.)_{4}\right)$ (b) performed at the secondorder Møller-Plesset perturbation theory (MP2) ${ }^{30}$ level using ORCA 4.2.1 ${ }^{31}$ and a computational scheme tested previously on the modeling of the structure and stability of monomeric Hg-thiolate complexes $^{29,32}$. The Ahlrichs polarized def2-TZVP $(\mathrm{Hg}, \mathrm{Se})$ and def2-SVP $(\mathrm{C}, \mathrm{H})$ basis sets were used in combination with the auxiliary def2-TZVP/C $\mathrm{C}^{33,34}$ Coulomb and exchange fitting basis to accelerate the MP2 calculations with the resolution of identity (RI) approximation ${ }^{35,36}$. For $\mathrm{Hg}$ atoms, scalar relativistic effects were accounted with an effective core potential $(\mathrm{ECP})^{37}$, as obtained from the Stuttgart pseudopotential library (60 core electrons, $l_{\max }=3$ ). The valence basis set used in connection with the ECP is based on a $(8 \mathrm{~s} 8 \mathrm{p} 6 \mathrm{~d} 1 \mathrm{f}) /[6 \mathrm{~s} 5 \mathrm{p} 3 \mathrm{~d} 1 \mathrm{f}]$ contraction scheme. The water solvent was represented with the SMD model ${ }^{38}$. The convergence for the self-consistent field (SCF) calculations was set to $10^{-8}$ a.u. Dark red, purple, gray, blue, red, and light gray spheres represent $\mathrm{Hg}, \mathrm{Se}, \mathrm{C}, \mathrm{N}, \mathrm{O}$, and $\mathrm{H}$, respectively. 

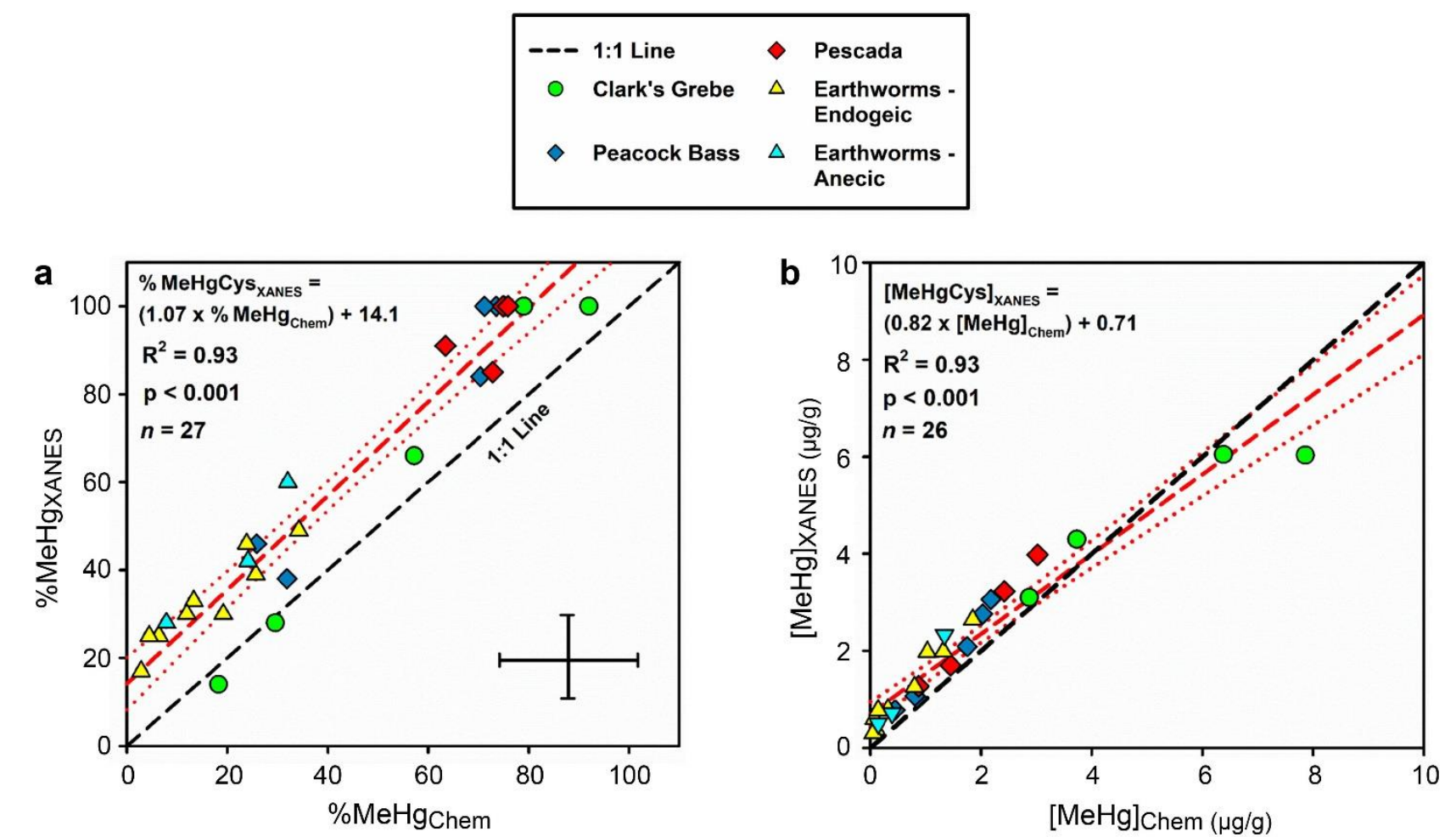

Figure S4. a) The accuracy of spectral fit results was evaluated by comparing the percentage of $\mathrm{Hg}$ as MeHg-thiolate complex determined by HR-XANES (\%MeHgCysXANES) and percentage of $\mathrm{MeHg}$ determined by chemical analyses $\left(\% \mathrm{MeHg}_{\mathrm{Chem}}\right)$. Maximum uncertainties in measurements are expressed as a generic error bar. b) The uncertainty in spectral fit results was evaluated by comparing the concentrations of $\mathrm{MeHg}$ determined by HR-XANES ([MeHgCys]Xanes $=\% \mathrm{MeHgCys}$ Xanes $\mathrm{x}$ $\left.[\mathrm{Hg}]_{\mathrm{Tot}}\right)$ and chemical analysis $\left([\mathrm{MeHg}]_{\mathrm{Chem}}\right)$. The dashed black line presents the 1:1 line, the dashed red line presents the linear fit of data, and the dotted red lines present the $95 \%$ confidence intervals of the fit. 


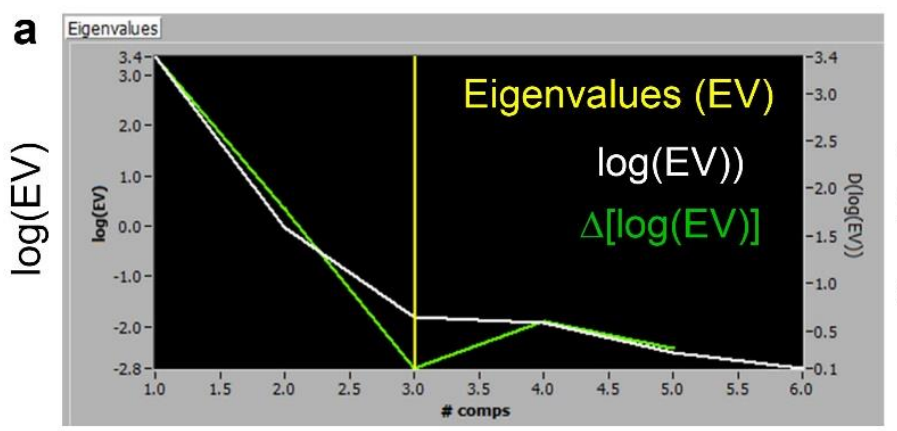

Number of PCA components

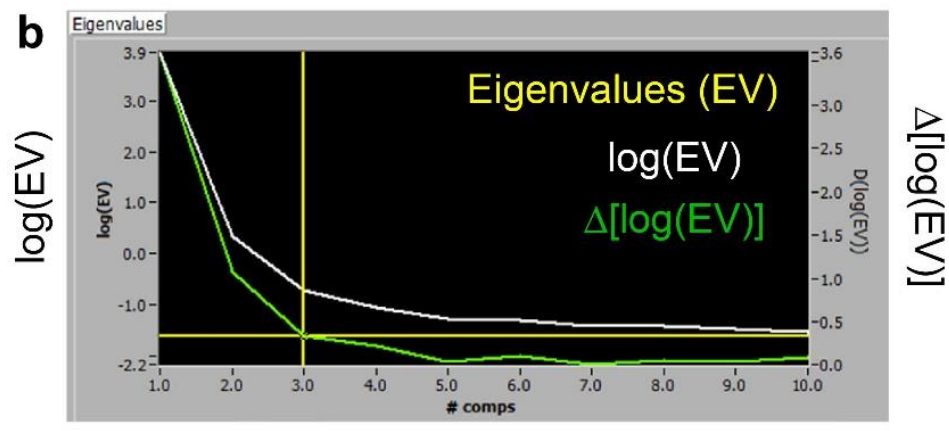

Number of PCA components

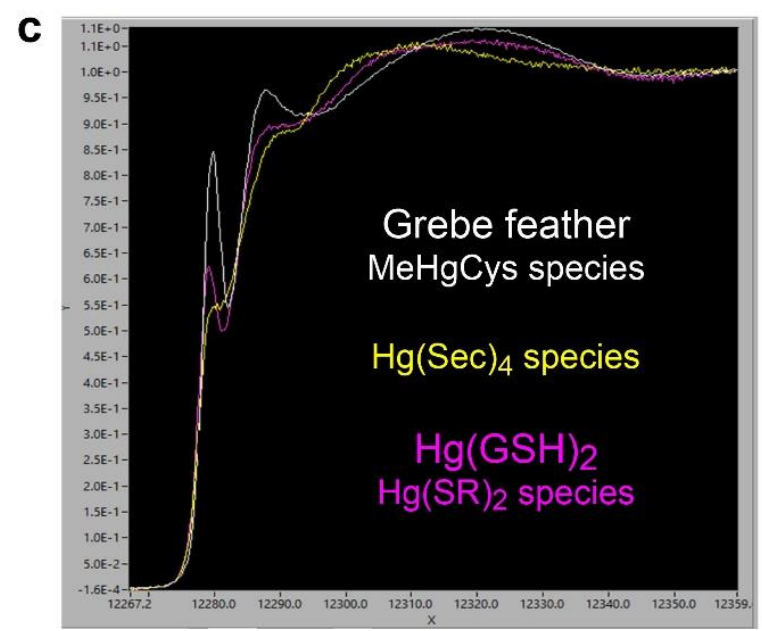

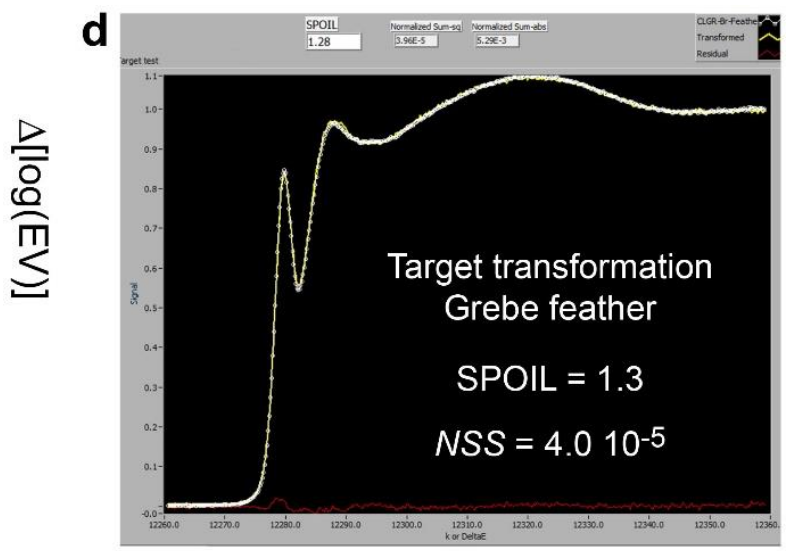
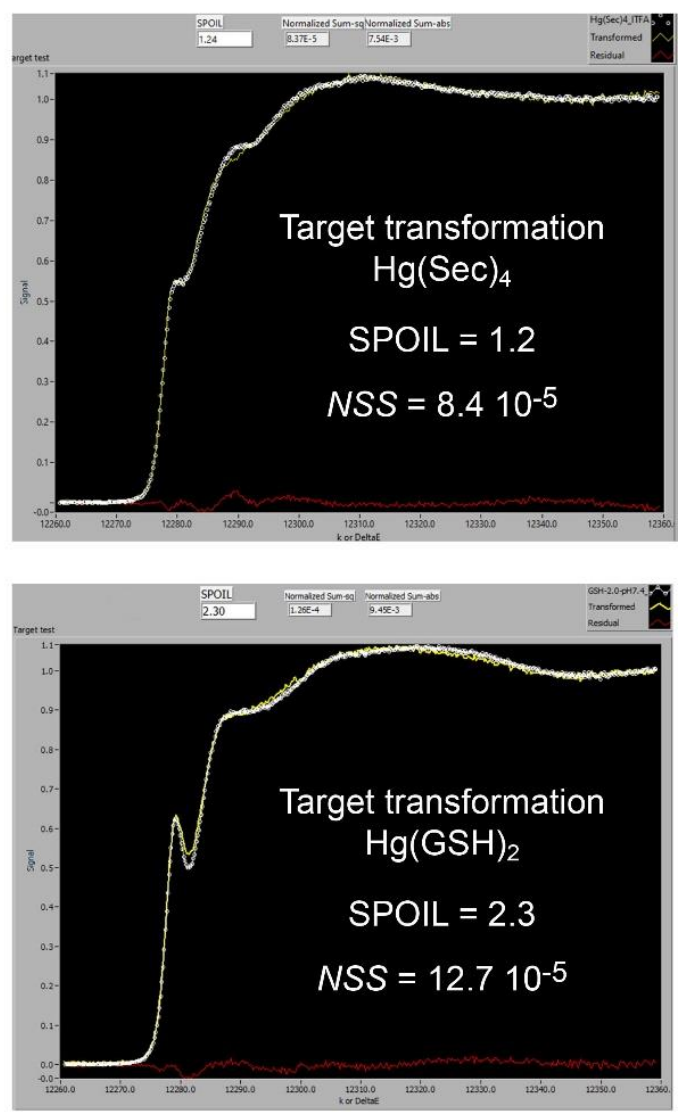

Figure S5. a,b) Estimation by principal component analysis (PCA) of the number of significant abstract components contained in the six HR-XANES spectra from the grebe (a), and the 10 fish +13 earthworm spectra (b). The curves are a scree plot of the components and the associated eigenvalues $(\mathrm{EV})^{39}$. The variance of each dataset can be accounted for with three components (i.e., Hg species). See ref. ${ }^{13}$ for details. c, Spectrum of $\mathrm{Hg}(\mathrm{Sec})_{4}$ identified by iterative transformation factor analysis $\left(\mathrm{ITFA}^{14}\right)$, and spectra of MeHgCys and $\mathrm{Hg}(\mathrm{SR})_{2}$ identified by target transformation analysis ${ }^{15}$ of a large library of $\mathrm{Hg}$ organic and inorganic model compounds ${ }^{10,17,18,28,29,32}$. $\mathrm{The} \mathrm{Hg}(\mathrm{SR})_{2}$ species was identified previously in fish contaminated by inorganic $\mathrm{Hg}(\mathrm{II})^{18}$. d) Target transformed spectra of the three $\mathrm{Hg}$ species. The quality of the reconstruction is evaluated with the SPOIL criteria ${ }^{15}$ and NSS value. SPOIL measures the degree to which replacing an abstract component with the candidate spectrum would increase the fit error. This is a non-negative dimensionless number for which values 
$<1.5$ are considered excellent, 1.5-3 good, 3-4.5 fair, 4.5-6 poor, and > 6 unacceptable. See ref. ${ }^{12}$ for details.
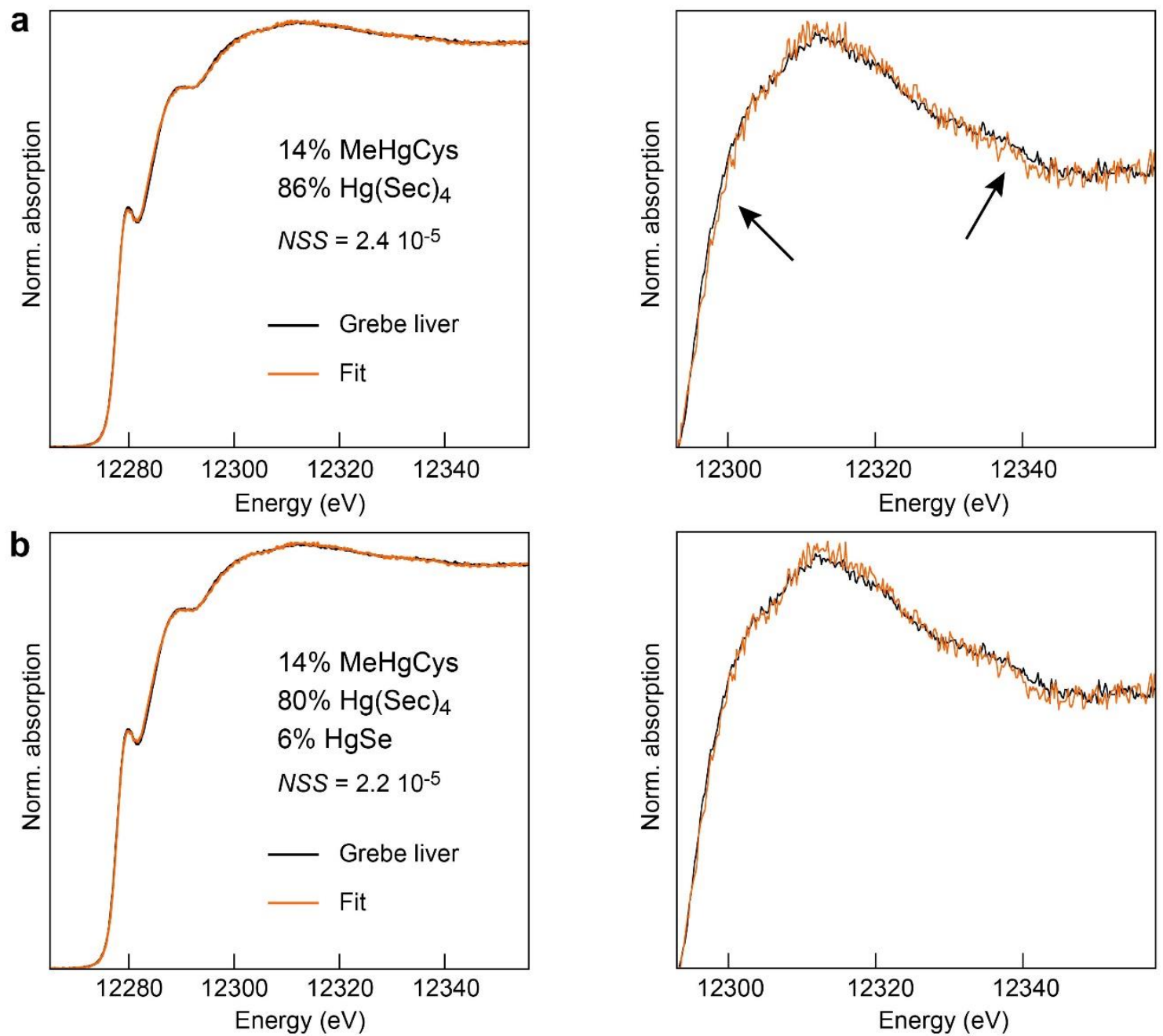

Figure S6. Least-squares fit of the liver HR-XANES spectrum of the Clark's grebe without HgSe (a) and with $\mathrm{HgSe}(\mathrm{b})$. The spectra on the right are an enlargement of the top-edge region where the $\mathrm{HgSe}$ reference gives a distinctive signal at the energies indicated with arrows. The fit lacks intensity at the diagnostic energies in the absence of the $\mathrm{HgSe}$ reference. Including $\mathrm{HgSe}$ provides a better fit of the entire grebe liver spectrum including in the diagnostic region where the data and reconstructed spectrum are now statistically superimposed. 
a $\begin{gathered}\mathrm{Hg}_{10} \mathrm{Se}_{20} \\ \mathrm{Se}: \mathrm{Hg}=2.0,\langle\mathrm{CN}\rangle=4.9\end{gathered}$

$\mathrm{d}\left(\mathrm{Hg}-\mathrm{Hg}_{1}\right)=4.30 \AA$

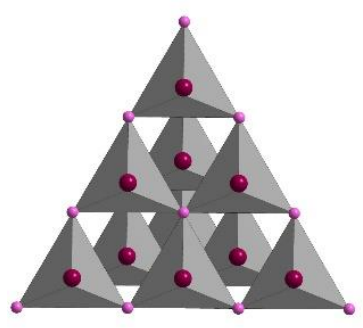

Hge ${ }_{20}$

Se: $\mathrm{Hg}=2.0,\langle C N\rangle=4.9$

$<\mathrm{d}\left(\mathrm{Hg}-\mathrm{Hg}_{1}\right)>=4.49 \AA, \mathrm{std}=0.26 \AA$

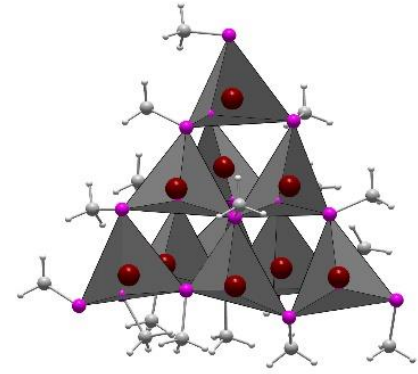

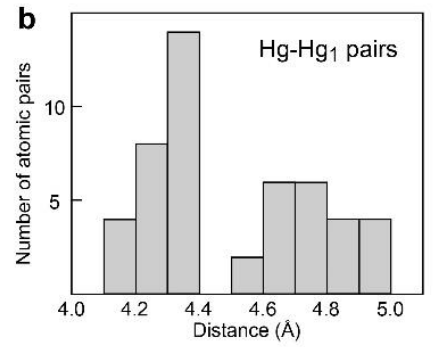

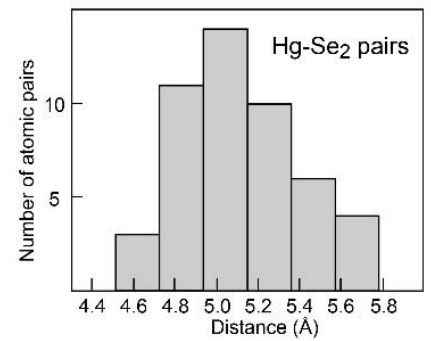

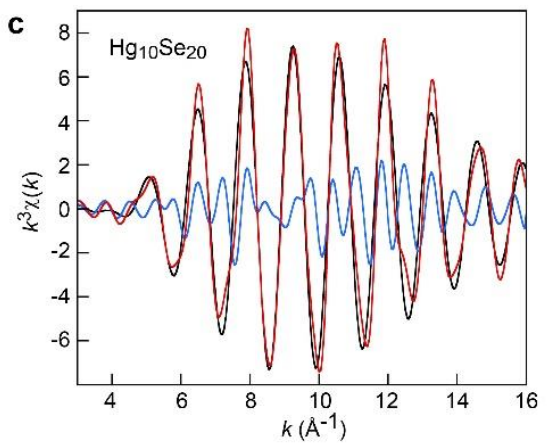
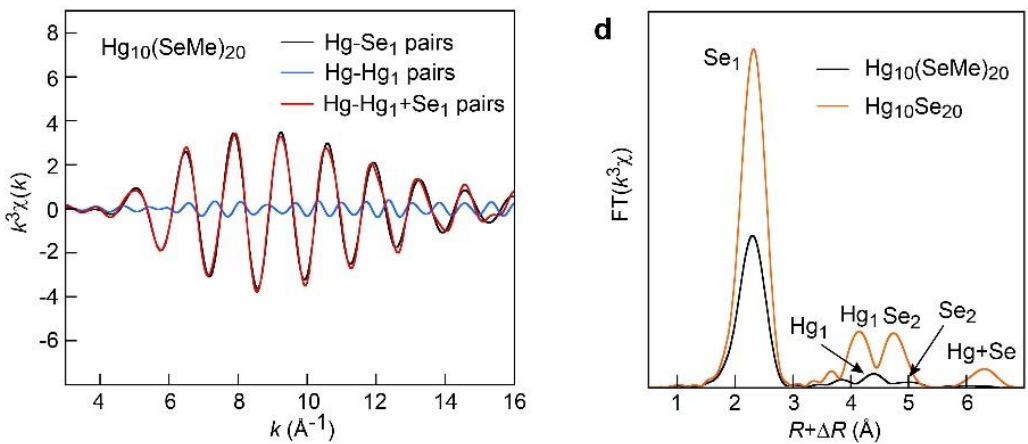

Figure S7. a) Polyhedral representation of a $\mathrm{Hg}_{10} \mathrm{Se}_{20}$ portion of the $\mathrm{HgSe}$ structure ${ }^{22}$, and the $\mathrm{Hg}_{10}(\mathrm{Sec})_{20}$ cluster optimized geometrically. The $\mathrm{Hg}_{10}(\mathrm{Sec})_{20}$ cluster has a predicted first shell $\mathrm{Hg}-\mathrm{Hg}_{1}$ distance of $4.49 \AA$ on average, close to the HR-EXAFS distance of $4.46 \AA$ in the grebe liver (Table S4), and $0.19 \AA$ longer than the crystallographic distance in $\mathrm{HgSe}(4.30 \AA)$. The optimization was performed at the PBE0-D3 DFT quantum level with def2-TZVP (Hg, Se) and def2-SVP (C, H) basis sets using ORCA 4.2.1 $1^{31}$. The water solvent was represented with the SMD model ${ }^{38}$. Sec residues were modeled with methaneselenolate $\left(\mathrm{CH}_{3} \mathrm{Se}^{-}\right)$. Dark red, $\mathrm{Hg}$; purple, Se; gray, $\mathrm{C}$, light gray, $\mathrm{H} . \mathrm{b}$ ) Population histograms of the predicted first shell $\mathrm{Hg}-\mathrm{Hg}_{1}$ and second shell $\mathrm{Hg}-\mathrm{Se}_{2}$ distances in $\mathrm{Hg}_{10}(\mathrm{Sec})_{20}$. Interatomic distances are counted in intervals of $0.1 \AA\left(\mathrm{Hg}-\mathrm{Hg}_{1}\right)$ and $0.2 \AA$ ( $\left.\mathrm{Hg}-\mathrm{Se}_{2}\right)$. The distributions of the interatomic distances are non-Gaussian with considerable asymmetry toward long distances. The $\mathrm{Hg}-\mathrm{Hg}_{1}$ and $\mathrm{Hg}-\mathrm{Se}_{2}$ distances partly overlap, whereas they are separated by $5.04-4.30$ $=0.74 \AA$ in $\mathrm{HgSe}$. c,d) Calculated EXAFS photoelectron waves using $\mathrm{FEFF} 7^{40}$ of the $\mathrm{Hg}-\mathrm{Hg}_{1}$ plus $\mathrm{Hg}-\mathrm{Se}_{1}$ pairs for $\mathrm{Hg}_{10} \mathrm{Se}_{20}$ and $\mathrm{Hg}_{10}(\mathrm{Sec})_{20}$ and Fourier transforms (radial structure function). The $\mathrm{Hg}$ $\mathrm{Hg}_{1}$ pair is extremely weak on the radial structure function, as a result of the large dispersion and asymmetry of the $\mathrm{Hg}-\mathrm{Hg}_{1}$ distances and the $\mathrm{Hg}-\mathrm{Hg}_{1} / \mathrm{Se}_{2}$ overlap. Few $\mathrm{Hg}-\mathrm{Hg}_{1}$ pairs are detected, despite the presence, on average, of $4.9 \mathrm{Hg}_{1}$ atoms around each $\mathrm{Hg}$ atom in the $\mathrm{Hg}$-selenolate cluster. The $\mathrm{Hg}-\mathrm{Se}_{1}$ bond lengths are also unequal and asymmetrical in $\mathrm{Hg}_{10}(\mathrm{Sec})_{20}$. 


$$
\begin{array}{lll} 
& \text { Clark's Grebe } \triangle \quad \begin{array}{l}
\text { Earthworms - } \\
\text { Acecic }
\end{array} \\
& \text { Peakcock Bass }---\mathrm{Se}: \mathrm{Hg}=4 \\
& \text { Pescada } \quad---\mathrm{Se}: \mathrm{Hg}=1 \\
\triangle & \begin{array}{l}
\text { Earthworms - } \\
\text { Endogeic }
\end{array}
\end{array}
$$
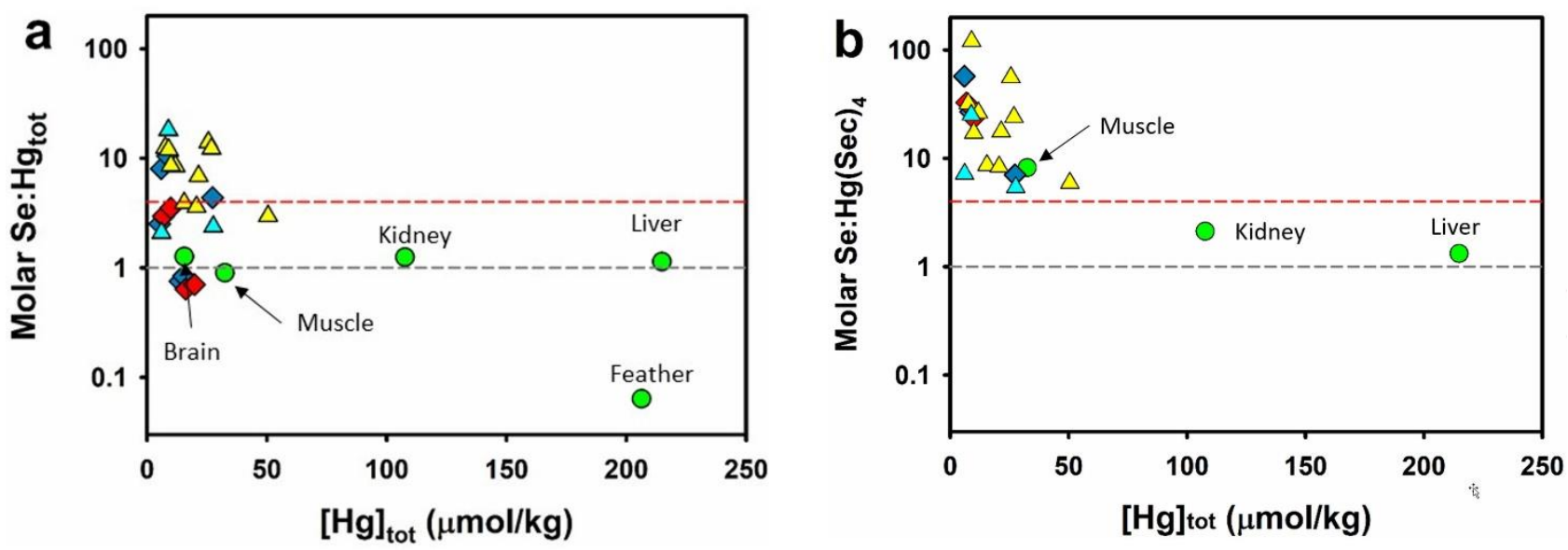

Figure S8. Molar ratios of Se to total $\mathrm{Hg}$ (Se: $\mathrm{Hg}_{\text {tot }}$ ) versus $\mathrm{Hg}_{\text {tot }}$ concentration (a) and $\mathrm{Se}$ to $\mathrm{Hg}$ as a tetraselenolate complex ( $\left.\mathrm{Se}: \mathrm{Hg}(\mathrm{Sec})_{4}\right)$ versus $\mathrm{Hg}_{\text {tot }}$ concentration (b) of the Clark's grebe, fish, and earthworm samples. Horizontal dashed lines present stoichiometric ratios of 4 (red) and 1 (gray) for reference of ratios of $\mathrm{Hg}(\mathrm{Sec})_{4}$ and $\mathrm{HeSe}$ species, respectively. Identities of the various Clark's grebe tissues are provided. All tissues are presented in plot (a), whereas only tissues with $\mathrm{Hg}(\mathrm{Sec})_{4}$ quantified by HR-XANES are presented in plot (b). Plot (b) shows that tissues containing $\mathrm{Hg}(\mathrm{Sec})_{4}$ have a $\mathrm{Se}: \mathrm{Hg}(\mathrm{Sec})_{4} \geq 4$ except for the Clark's grebe kidneys (Se: $\mathrm{Hg}(\mathrm{Sec})_{4}=2.1 \pm 0.3$ ) and liver tissues ( $\mathrm{Se}: \mathrm{Hg}(\mathrm{Sec})_{4}=1.3 \pm 0.2$ ), the latter confirmed to contain $\left.\mathrm{Hg}_{\mathrm{x}}(\mathrm{Se}, \mathrm{Sec})_{\mathrm{y}}\right) /$ nanoparticulate $\mathrm{Hg}$ selenide by HR-EXAFS analysis (Figure S9). 

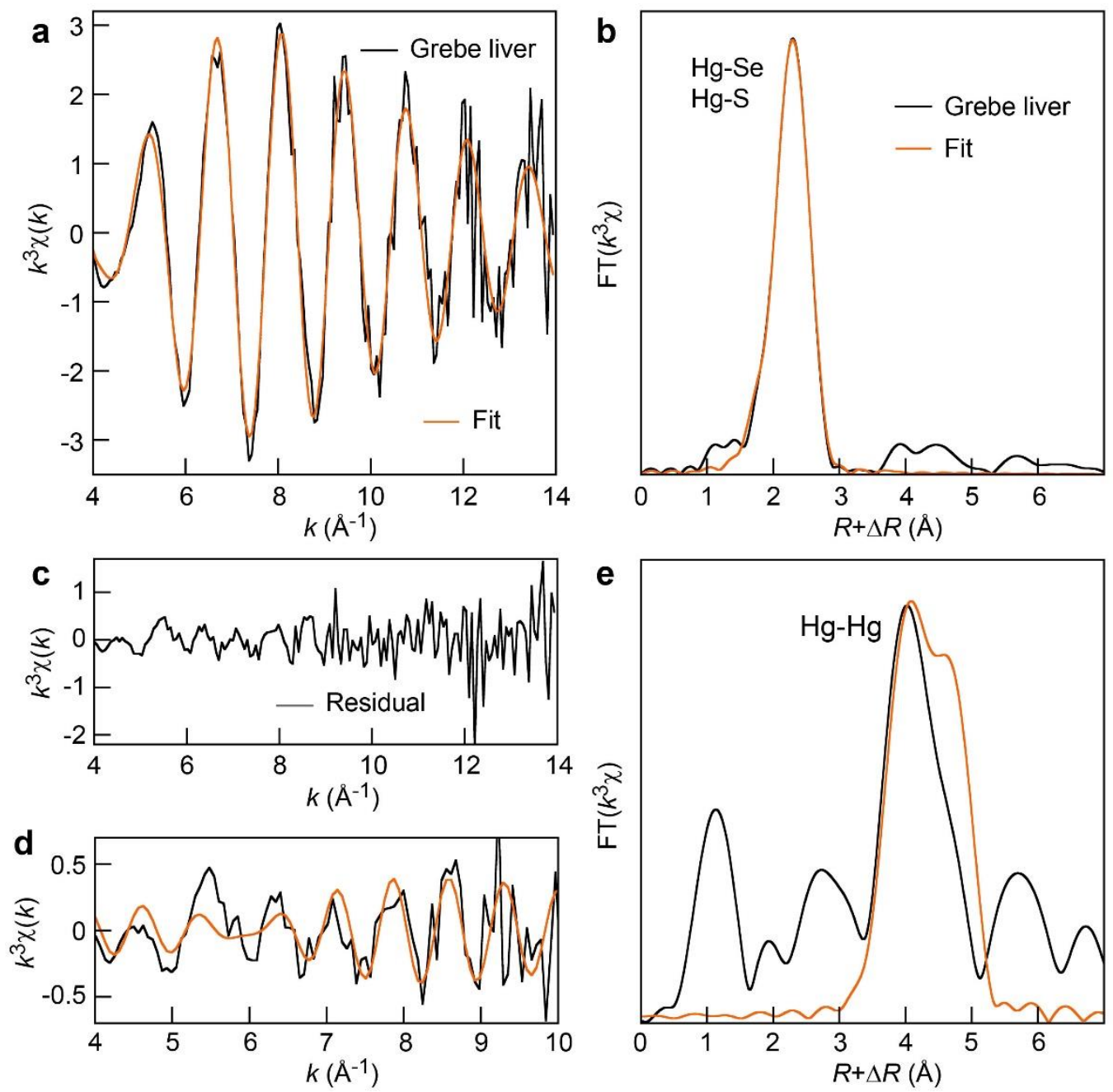

Figure S9. a,b) Fit of the HR-EXAFS spectrum and Fourier transform (radial structure function) for the Clark's grebe liver with $\mathrm{Hg}$-Se and $\mathrm{Hg}$-S pairs in the first coordination shell and no Hg-Hg-pairs in the second coordination shell. c, Residual of the HR-EXAFS fit, showing clear evidence for significant spectral structures above noise level that are not accounted for by the $\mathrm{Hg}-(\mathrm{Se}, \mathrm{S})$ model-fit. c,d) Fit of the HR-EXAFS residual and Fourier transform with $\mathrm{Hg}-\mathrm{Hg}$ pairs, demonstrating their detection by HR-EXAFS. HR-EXAFS detects $2.1 \pm 0.5 \mathrm{Hg}$ atoms at $4.46 \pm 0.03 \AA$ with a static disorder of $\sigma=0.1 \AA$ (Table S4). The distribution of the Hg-Hg distances was considered to be Gaussian in the analysis, which is incorrect when the local structure is highly disordered (e.g., $\sigma \geq \sim 0.1 \AA^{41,42}$ ) (Figure $\mathrm{S} 7 \mathrm{~b}$ ). An analysis of disordered systems using symmetrical distributions results in "lost" atoms, which means that $\mathrm{Hg}$ is in all likelihood surrounded by more than $2.1 \mathrm{Hg}$ atoms. If all the $\mathrm{Hg}-\mathrm{Hg}$ pairs were from the $6 \% \mathrm{HgSe}$ detected by HR-XANES (Figure S6b), the number of $\mathrm{Hg}$ atoms would be $12 \times 0.06$ $=0.7$. We conclude from this analysis that the majority of the $\mathrm{Hg}$ atoms detected by HR-EXAFS are from $\mathrm{Hg}_{\mathrm{x}}(\mathrm{Se}, \mathrm{Sec})_{\mathrm{y}}$ clusters. Their existence is also supported by the $\mathrm{Hg}-\mathrm{Hg}$ distance of $4.46 \pm 0.03 \AA$, which is $0.16 \AA$ longer than the $\mathrm{Hg}-\mathrm{Hg}$ distance in $\mathrm{HgSe}$, and in agreement with the predicted average $\mathrm{Hg}-\mathrm{Hg}$ distances for disordered $\mathrm{Hg}_{\mathrm{x}}(\mathrm{Se}, \mathrm{Sec})_{\mathrm{y}}$ cluster models (Figures. S7 and S16). 


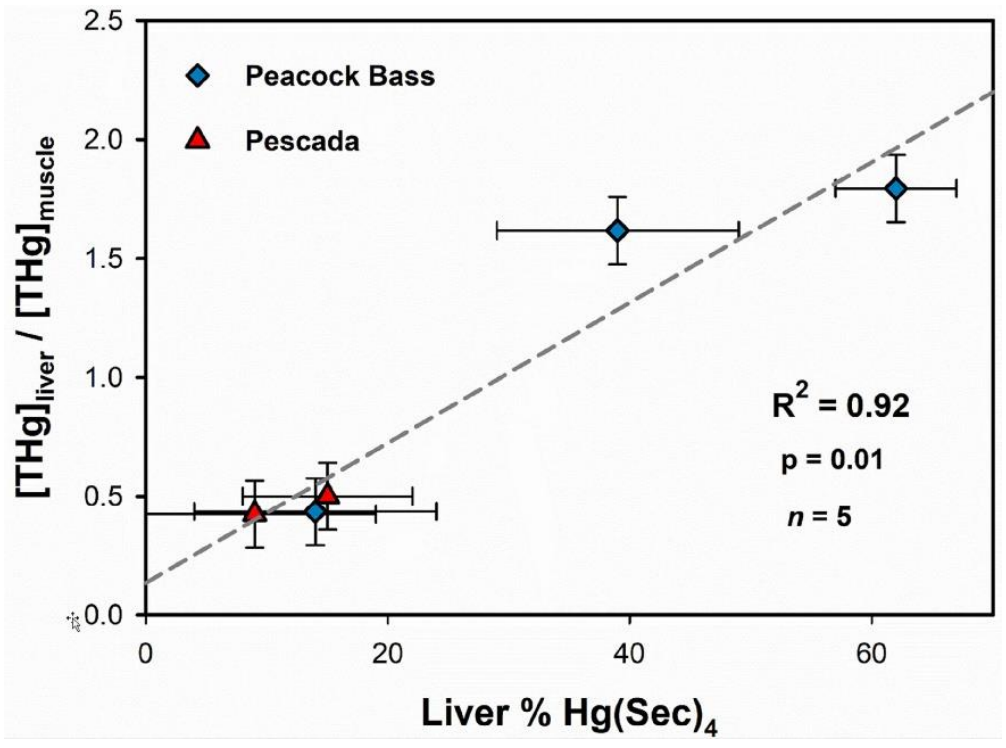

Figure S10. Positive correlation between the total $\mathrm{Hg}$ concentration ratio between liver and muscle $\left([\mathrm{Hg}]_{\text {liver }} /[\mathrm{Hg}]_{\text {muscle }}\right)$ and the percentage of the demethylated fraction of $\mathrm{Hg}\left(\% \mathrm{Hg}(\mathrm{Sec})_{4}\right)$ in the liver tissue of peacock bass. Horizonal error bars present uncertainty in spectral fit data, and vertical error bars present the total propagated error for the ratio of total $\mathrm{Hg}$ measurements. The dashed gray line presents the linear fit of data.

a Control (plasmid $h g c A)$

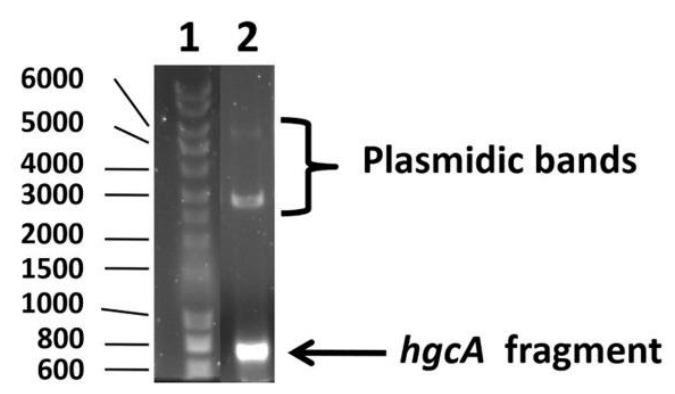

C Earthworms: Site S1

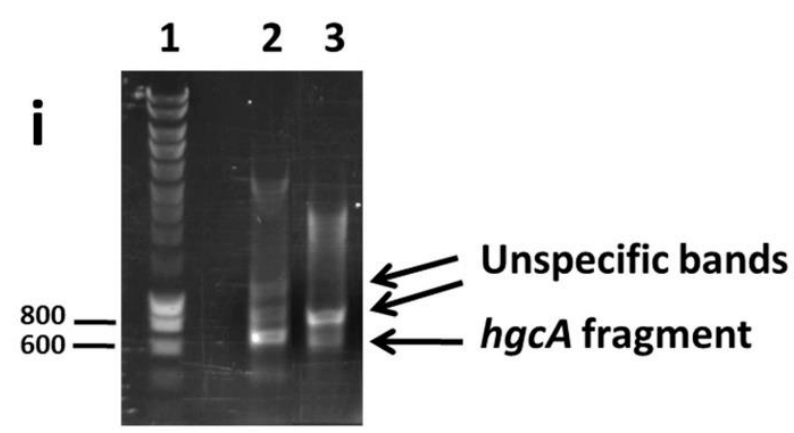

\section{b Soil (Site S2)}

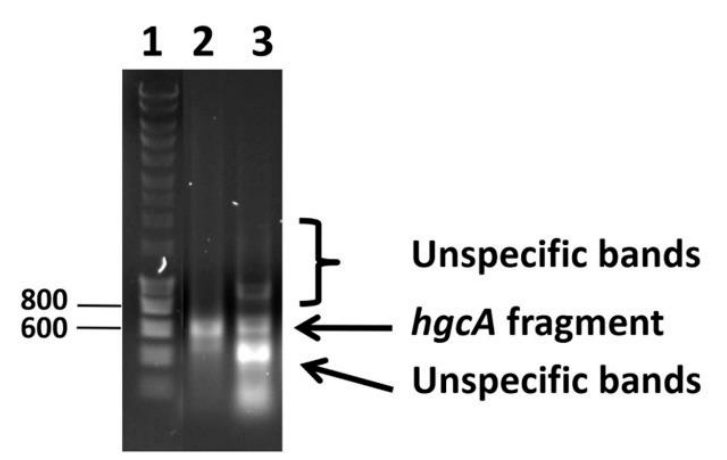

Earthworms: Site S2

$$
\begin{array}{llll}
1 & 2 & 3 & 4
\end{array}
$$

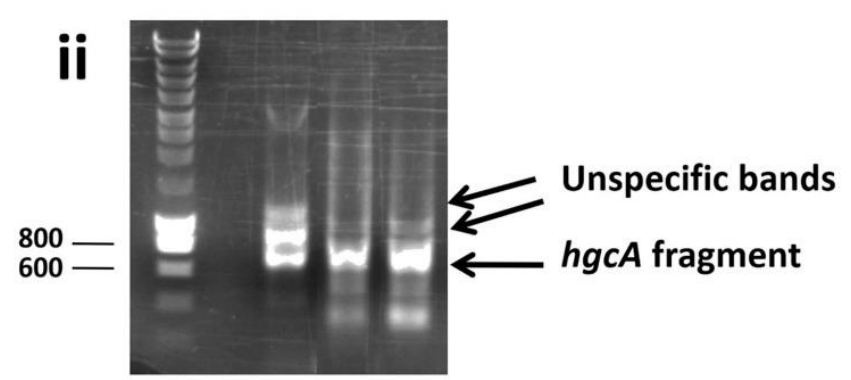


Figure S11. Agarose gel electrophoresis results. a) Shows the control amplification of an hgcA gene fragment of $650 \mathrm{bp}$ from a plasmid harboring a cloned fragment of the $h g c A$ gene using primers hgcAF and hgcA-912R and DreamTaq polymerase. Lane 1 - molecular ladder; lane 2 - PCR made up with $200 \mathrm{ng}$ of plasmid and primers hgcA-F + hgcA-912R; band at approximately 650-700 bp. b) Shows the amplification of an $h g c A$ gene fragment of approximately $630 \mathrm{bp}$ from total genomic DNA extracted from soil at site S2. Lane 1 - molecular ladder; lane 2 - control PCR with $h g c A$-harboring plasmid (40 ng per reaction); lane 3 - PCR made up with total genomic DNA extracted from the site S2 soil (120 ng of genomic DNA per reaction were used). c) Shows the amplification of hgcA gene fragments of approximately 630 to $650 \mathrm{bp}$ from earthworm digestive microflora from sites S1 (panel i) and S2 (panel ii). Panel i, Lane 1 - molecular ladder; lane 2 - control PCR with hgcA-harboring plasmid (40 ng per reaction); lane 3 - PCR of the total genomic DNA extracted from the microflora of an anecic earthworm from site S1. Panel ii, Lane 1 - molecular ladder; lane 2 - control PCR with hgcA-harboring plasmid (40 ng per reaction); lanes 3 and 4 - PCRs of the total genomic DNA extracted from the microflora of earthworms from site S2, either anecic (lane 3) or endogeic (lane 4).

a. Nucleotide (633 bp) and translated protein sequences (211 amino acids) of the $h g c A$ gene fragment amplified from soil and earthworm DNA

ggggtcaatgtatggtgcgcggccggcaaagggaccttcggcacgacggaactgctggcc $\begin{array}{llllllllllllllllllll}G & V & N & V & \text { W } & C & A & A & G & K & G & T & F & G & T & T & E & I & L & A\end{array}$ cagatcagcgcgaccaatctcgccgccatcgtcagccaccgccagctgatcctgcogatc $\begin{array}{llllllllllllllllllll}Q & I & S & A & T & N & \text { L } & \text { A } & \text { A } & \text { I } & \text { V } & \text { S } & \text { H } & \text { R } & \text { Q } & \text { L } & \text { I } & \text { L } & \text { P } & \text { I }\end{array}$ ctcggegcgcogggagtggeggcgcacgaggtaaagcaacagagcggcttcaccgtccgc $\begin{array}{llllllllllllllllllll}\text { L } & G & \text { A } & \text { P } & \text { G } & \text { V } & \text { A } & \text { A } & \text { H } & \text { E } & \text { V } & \text { K } & Q & Q & \text { S } & \text { G } & \text { F } & \text { T } & \text { V } & \text { R }\end{array}$ tacgggacgatccgcgetgccgatctcccogactatctcgacaacggtctggtcactacc

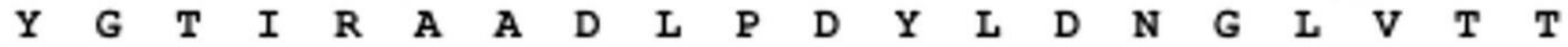
ccggcaatgcaggagctgacettcactctctacgaacggctggtcetcctcceggtcgag $\begin{array}{llllllllllllllllllll}\mathbf{P} & \mathrm{A} & \mathrm{M} & \mathbf{Q} & \mathrm{E} & \mathrm{L} & \mathrm{T} & \mathrm{F} & \mathrm{T} & \mathrm{L} & \mathrm{Y} & \mathrm{E} & \mathrm{R} & \mathrm{L} & \mathrm{V} & \mathrm{L} & \mathrm{L} & \mathrm{P} & \mathrm{V} & \mathrm{E}\end{array}$ atcatccacgccetgaaatcggcggcagtcatcaccetgagcctcttcctcctcggcctc $\begin{array}{llllllllllllllllllll}\text { I } & I & \text { H } & \text { A } & \text { L } & \text { K } & \text { S } & \text { A } & \text { A } & \text { V } & \text { I } & \text { T } & \text { L } & \text { S } & \text { L } & \text { F } & \text { L } & \text { L } & G & \text { L }\end{array}$ cttgcoggcgggaacgccagcgccagccggatgatcctcgcctatctcggtgccetcttc

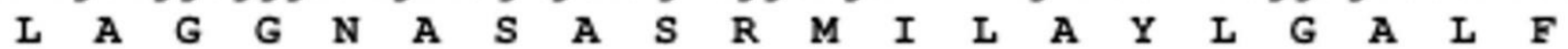
agcggcatcgtcgtcgggcccetcctcctccctggctgcoggggcggagtttcgccgtc

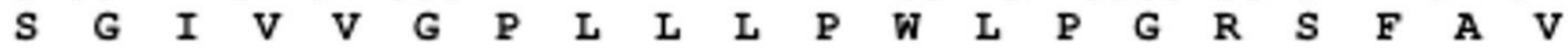
aaggggggagtcgtcggtctactctggtcgtttctctgctatcgattgatcggtgctgac $\begin{array}{llllllllllllllllllll}\text { K } & G & G & \text { V } & \text { V } & \text { G } & \text { L } & \text { L } & \text { W } & \text { S } & \text { F } & \text { L } & \text { C } & \text { Y } & \text { R } & \text { L } & \text { I } & \text { G } & \text { A } & \text { D }\end{array}$ tggaacctggcceagacgetggeggceggtctggcgctgceggcgetgagcgetttttac

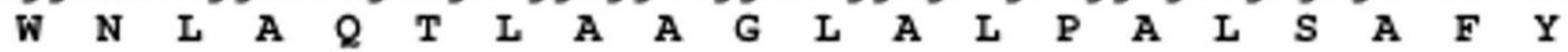
accetcaactacaccggctgcacccctacacc

$\begin{array}{lllllllllll}\text { T } & \text { L } & \text { N } & \text { Y } & \text { T } & \text { G } & \text { C } & \text { T } & \text { P } & \text { Y } & \text { T }\end{array}$ 
b. Comparison of nucleotide sequences of the $h g c A$ gene fragment amplified from soil and earthworm DNA (633 bp) and the best match from the NCBI database (KJ021090, Geobacteraceae clone B2_FE06).

This study KJ021090

This study KJ021090

This study

KJ021090

This study KJ021090

This study

KJ021090

This study

KJ021090

This study

KJ021090

This study KJ021090

This study KJ021090

This study KJ021090

This study KJ021090

GGGGTCAATGTATGGTGCGCGGCCGGCAAAGGACCTTCGGCACGACGGAACTGCTGGCC GGCATCAACGTCTGGTGTGCGGCGGGGAAGGGACCTTCGGTACGGAGGAATGGTTCGG

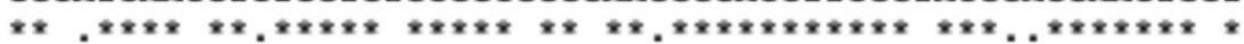

CAGATCAGCGCGACCAATCTCGCCGCCATCGTCAGCCACCGCCAGCTGATCCTGCCGATC CGGGTCGGTGCAACCGGACTGGCAAAAGTTGTAATCCATCGGCGGCTGCTCCTGCCGATC

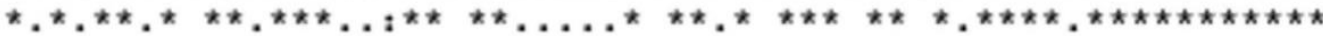

CTCGGCGCGCCGGGAGTGGCGGCGCACGAGGTAAAGCAACAGAGCGGCTTCACCGTCCGC CTCGGCGCCCCGGGTGTGGCGGCGCACGAAGTGGCCAAGCGCACCGGCTTTGCGGTGAGC

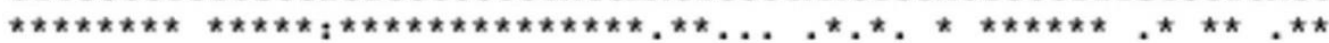

TACGGGACGATCCGCGCTGCCGATCTCCCCGACTATCTCGACAACGGTCTGGTCACTACC TATGCCAGCATCAGAGCCGAAGACCTTCCGGAATATCTGGAACATGGCATGGTCACCACG

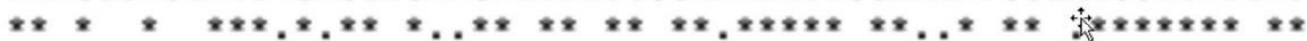

CCGGCAATGCAGGAGCTGACCTTCACTCTCTACGAACGGCTGGTCCTCCTCCCGGTCGAG CCAACCATGCGGGAGCTGACCTTTACCTTCCGGGAACGGCTGGTTTTAGTGCCGGTGGAA

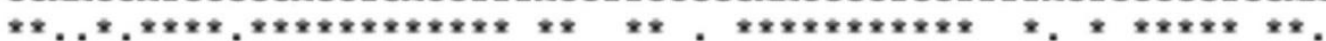

ATCATCCACGCCCTGAAATCGGCGGCAGTCATCACCCTGAGCCTCTTCCTCCTCGGCCTC GTGGTTCATGCCTTGAAGTCGACGGCGGTCATCGCGCTTTGCCTGTTCGTCCTGGGGGCT

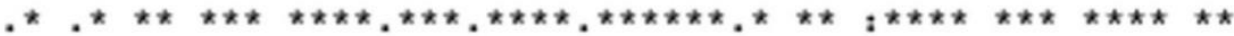

CTTGCCGGCGGGAACGCCAGCGCCAGCCGGATGATCCTCGCCTATCTCGGTGCCCTCTTC GTCCTGGGCGGGTCCATAACCGGCATAACGGCGAGTATCGCCTATCTCGGAGCGGTCTTC

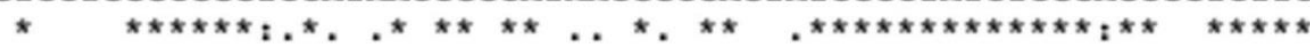

AGCGGCATCGTCGTCGGGCCCCTCCTCCTCCCCTGGCTGCCGGGGCGGAGTTTCGCCGTC ACCGGGATCGTCCTCGGCCCGCTGCTCCTCCCCTGGCTTCCGGGAAGGAGTTTTTCCGTC

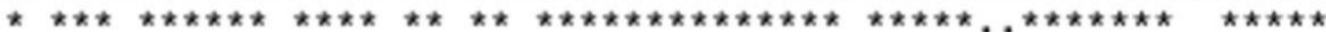

AAGGGGGAGTCGTCGGTCTACTCTGGTCGTTTCTCTGCTATCGATTGATCGGTG---CT AAGGGCGCCAGCGCCGGACTGGCCTGGAGCGCCGTCTGGTATGGGATCGCCGGCGGCAGT

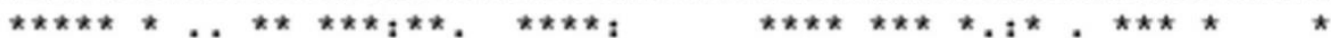

GACTGGAACCTGGCCCAGACGCTGGCGGCCGGTCTGGCGCTGCCGGCGCTGAGCGCTTTT ACCTGGAGCACACCGACGACCATCGCCGCCTTCCTGGCACTCCCGGCGGTGAGCGCTTTC

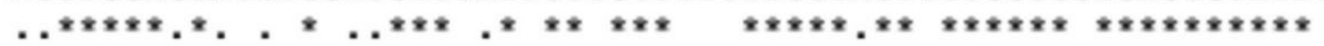

TACACCCTCAACTACACCGGCTGCACCCCCTACACC TACACGCTCAACTACACCGGCTGCACCCCCTACACC

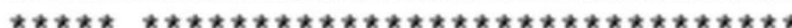


c. Comparison of amino acid sequences from the $h g c A$ gene fragment amplified from soil and earthworm (211 residues) and the best match from the NCBI database (AHL38020, Geobacteraceae).

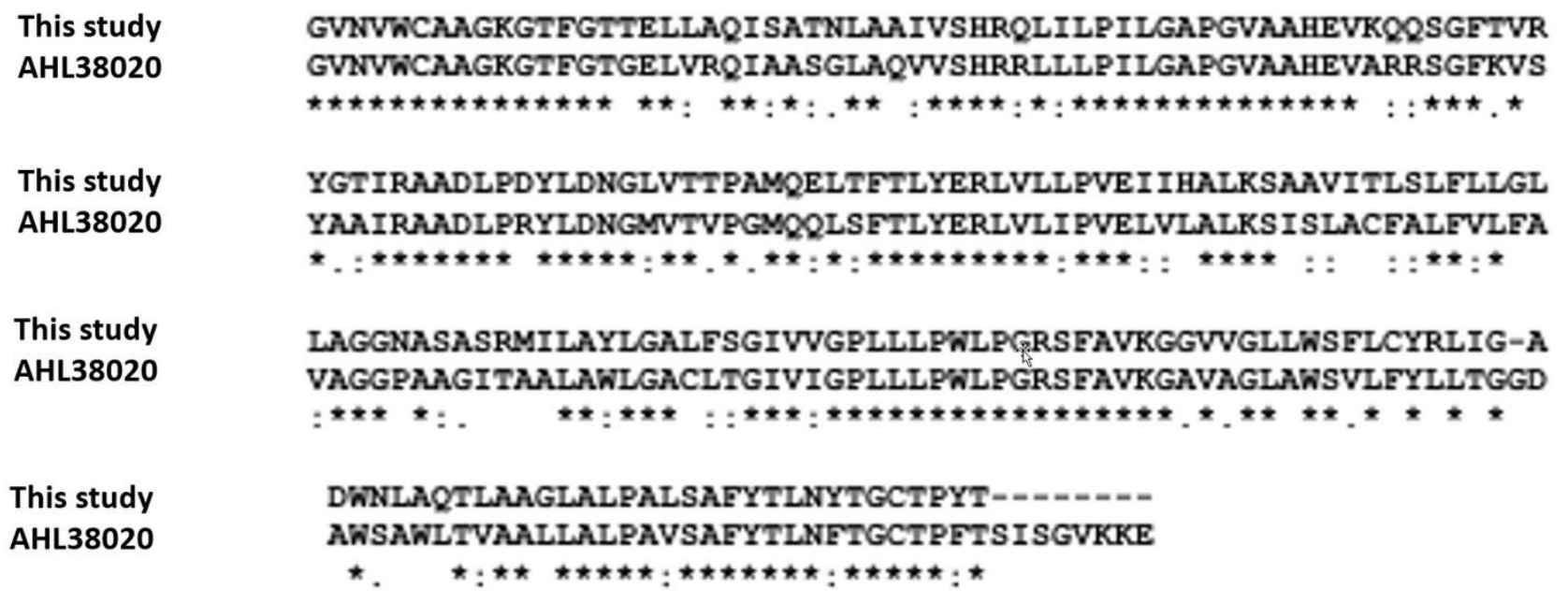

Figure S12. a) The nucleotide sequence ( $633 \mathrm{bp}$ ) and translated single-letter amino acid sequence (211 residues) of the amplified $h g c A$ gene fragment from soil and earthworms. b) A comparison between the nucleotide sequence of the amplified $h g c A$ gene fragment from soil and earthworms and the best matching sequence (NCBI web site, KJ021090, Geobacteraceae clone B2_FE06). c) A comparison between the amino acid sequence of the amplified $h g c A$ gene fragment from soil and earthworms and the best matching sequence (NCBI web site, AHL38020, Geobacteraceae). The asterisks, colon, and period denote residues that are identical, have strongly similar properties, and have weakly similar properties, respectively. 


\section{a Multiple sequence alignment (various unrelated species)}

sapiens
mouse
grebe
zebrafish
sapiens
mouse
grebe
zebrafish

sapiens
mouse
grebe
zebrafish

sapiens
mouse
grebe
zebrafish

MWRSLGLALALCLLPSGGTESQDQSSLCKQPPAWS IRDQDPMLNSNGSVTVVALLQASUY MWRSLGLALALCLLPYGGAESQGQSSACYKAPEWY IGDQNPMLNSEGKVTVVALLQASUY MWAGLGLVLALCLLPGGGTEIQN----CKEPPEWH IGEENPMLSSRGSVTVVALLQASUY MWKALSLTLALCLLVGCSAESETEGARCKLPPEWKVGDVEPMKNALGQVTVVAYLQASUL **..*.***** .:*: : * .* : : :**.: *.*********

LCILQASKLEDLRVKLKKEGYSNISYIVVNHQGISSRLKYTHLKNKVSEHIPVYQQEENQ LCLLQASRLEDLRIKLESQGYFNISYIVVNHQGSPSQLKHSHLKKQVSEHIAVYRQEEDG MCLLQASRLEDLRVKLENEGLVNISYVVVNHQGSYSQRKFHLLKERVSNYITVYQQDEQQ FCLEQASKLNDLLLKLEKQGYPNIAYMVVNNREERSQRLHHLLQERLLN-ITLYAQDLSQ

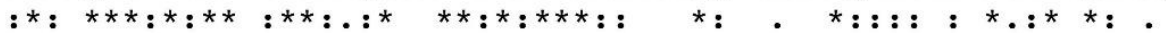

TDVWTLLNGSKDDFLIYDRCGRLVYHLGLPF SFLTFPYVEEAIKIAYCEKKCGNCSLTTL IDVWTLLNGNKDDFLIYDRCGRLVYHLGLPYSFLTFPYVEEAIKIAYCEERCGNCNLTSL ADVWTTLNGNKDDFLIYR-CGRLVYHLGLPYSFLSFQYVEESIKIAYCENKCGNCSYTEP PDAWQAVNAEKDDILVYDRCGRLTYHLSLPYTILIHPHVEEAIKHTYCDRICGECSLESS ** : *..**:*:* ****.***.**:: :* . :***:** :**: .**:*.

KDEDFCERVSLATVDKTVET--------PSPHYHHEHHHNHGHQHLGSSELSENQQPGAP EDEDFCKTVTSATANKTAEP--------SEAHSHHKHHNKHGQEHLGSSKPSENQQPGPS AIDDICENITKTADEKLAEPEPKPTGQHSHHHNLHRHRHHHHHHHREGSRHSKNENHQNS AQLEECKKATEEVNKPVEEE----------PRQDHGHHEQGHHEHQGEAERHRHG-----
: *:
*
: * * : : : .* : . :

NAPTHPAPPGLHHHHKHKGQHRQGHPEN--RDMPASEDLQDLQKKLCRKRCINQLLCKLP --ETTLPPSGLHHHHRHRGQHRQGHLESUDTTASEGLHLSLAQRKLURRGCINQLLCKLS SETQRHHPHSGHNRHDHTGSHEQVDTVPPGESVEISQDKKLU--KKGKTSCKNQLTUNWQ ----HHHPHHHHHHHRGQQQVDVDQQVLSQVDFGQVAVETPMMKRPUAKHSRUKVQYSUQ * *: : * . . $\quad$ : $\quad:$ :

TDSELAPRSUCCHCRHLIFEK-TGSAIT-UQCKENLPSLCSUQGLRAEENITES-CQURL KESEAAPS SCCCHCRHLIFEK-SGSAIA-UQCAENLPSLCSUQGLFAEEKVTES-CQCRS TASDSASSSUCCHURHLLFEE-LGNSVT-UQCRGALPNSCRUHGQLSAEDITES-UQURL QGADSPVASUCUHURQLFGGEGNGRVAGLUHCDEPLPASUPUQGLKEQDNH IKETUQURP

$$
\text { : : * : * * * : : : * * : * } * \text { : * * : . : : : : * }
$$

-PPAAUQISQQLIPTEASASURUKNQAKKUEUPSN

-PPAAUQ-NQPMNPMEANPNUSUDNQTRKUKUHSN

-LTAAUQ-SPAAGASETSDTUQUQEKARNUAUKTN

APPAEU--------ELSQPTUVUPAGDATUGURKK

$$
\text { ..* * . } * * \text { * * }
$$




\section{b Multiple sequence alignment (various bird species)}

grebe crane pelican hoatzin penguin emperor cormorant ibis tropicbird loon fulmar

grebe crane pelican hoatzin penguin emperor cormorant ibis tropicbird loon fulmar

grebe crane pelican hoatzin penguin emperor cormorant ibis tropicbird loon fulmar

grebe crane pelican hoatzin penguin emperor cormorant ibis tropicbird loon fulmar
MWAGLGLVLALCLLPGGGTEIQNCKEPPEWHIGEENPMLSSRGSVTVVALLQASUYMCLL MWAGLGLVLALCLLPGGGTEIQNCKEPPEWHIGEENPMLNTRGSVTVVALLQASUYLCLL MWAGLGLVLALCLLPGGGTEIQNCKEPPEWHIGEENPMLNSRGSVTVVALLQASUYLCLL MWAGLGIVLALCLLPGGGTEIQNCKEAPEWRIGEEDPMLNSRGSVTVVALLQASUYLCVL MWAGLGLVLALCLLSGGGTEIQNCKEPPEWRIGEENPMLNSRGSVTVVALLQASUYLCLL MWAGLGLVLALCLLSGAGTEIQNCKEPPEWRIGEENPMLNSRGSVTVVALLQASUYLCLL MWAGLGLVLALCLLPGGGTEIQNCKEPPEWRIGEENPMLNSRGSVTVVALLQASUYLCLL MWAGLGLVLALCLLPGGGTEIQNCKEPPEWRIGEENPMLNSRGSVTVVAPLQASUYLCLL MWAGLGLVLAVCLLPGGGTE IQNCREPPEWRIGEENPMLNSRGSVTVVALLQASUYLCLL MWAGLGLVLALCLLPGGGTEIQNCKEPPEWRIGEENPMLNSRGSVTVVALLQASUYLCLL

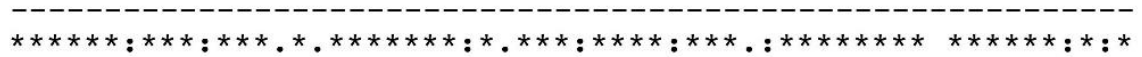

QASRLEDLRVKLENEGLVNISYVVVNHQGSYSQRKFHLLKERVSNYITVYQQDEQQADVW QASRLEDLRVKLENKGLFNISYVVVNHQGTYSQKKFHLLKERVSEY ITVYQQDEQQDDVW QASRLEDLRVKLQNEGLVNISYVVVNHQGTYSQRKFHLLKESVSDYITVYQQDEQQADVW QASRLEDLRVKLVNEGLVNISYVVVNHQGPSSRRKFHLLKESVSDSITVYQQDEQQDDVW QASRLEDLRVKLENEGLVNISYVVVNHQGTYSQRKFHLLKESVSDY ITVYQQDEQQADVW QASRLEDLRVKLENEGLVNISYVVVNHQGTYSQRKFHLLKESVSDYITVYQQDEQQADVW QASRLEDLRVKLENEGLVNISYVVVNHQGTSSQRKIHLLKASVSDYVTVYQQDEQQADVW QASRLEELRVKLENEGLVNISYVVVNHQGTYSQRKFHLLKESVSDY ITVYQQDEQQADVW QASRLEDLRVKLQNEGLVNISYVVVNHQGTSSQRKFHLLKESVSDY ITVYQQDEQQADVW QASRLEDLRVKLENEGLVNISYVVVNHQGTSSQRKFHLLKESVSDS ITVYQQDEQQADVW<smiles>[Y]#[W]</smiles>

TTLNGNKDDFLIYR-CGRLVYHLGLPYSFLSFQYVEES IKIAYCENKCGNCSYTEPAIDD TTLNGNKDDFLIYDRCGRLVYHLGLPYSFLSFQYVEES IKIAYCENKCGNCSYTEPDIDV TTLNGNKDDFLIYDRCGRLVYHLGLPYSFLSFQYVEES IKIAYCENKCGNCSYTEPDIDG TTLNGNKDDFLIYDRCGRLVYHLGLPYSFLSFQYVEDS IKIAYCENKCGNCSYTEPGIDG TTLNGNKDDFLIYDRCGRLVYHLGLPYSFLSFQYVEES IKIAYCENKCGNCSYMEPEIDG TTLNGNKDDFLIYDRCGRLVYHLGLPYSFLSFQYVEES IKIAYCENKCGNCSYMEPEIDG TTLNGSKDDFLIYDRCGRLVYHLGLPYSYLSFQYVEES IKIAYCENKCGNCSYMEPDIDG TTLNGNKDDFLIYDRCGRLVYHLGLPYSFLSFQYVEES IKIAYCENKCGNCSYTEPDIDG TTLNGNKDDFLIYDRCGRLVYHLGLPYSFLSFQYVAES IKIAYCENKCGNCSYMEPDIDG ATLNGNKDDFLIYDRCGRLVYHLGLPYSFLSFQYVEESIKIAYCENKCGNCSYMEHDIDG GQIGTIKIPSRTLDRCGRLVYHLGLPYSFLSFQYVEES IKIAYCENKCGNCFYMEPDIGG

:. $\quad * \quad * * * * * * * * * * * * *: * * * * *: * * * * * * * * * * * * * * * * *$.

ICENITKTADEKLAEPEPKPTGQHSHHHNLHRHRHHHHHHHREGSRHSKNENHQNSSETQ ICENITKKTDEKLSEIEPKPTGQHSHHHSLHRHRHHHHHHR-EGGRHSKNENHQTPSESQ VCKNITQKADEKLTEIEPKPTGQHSHHHSLHRHRQHHHREG---SRHSKNENHQASSETQ ACENITKKADEKLAEIEP IPTGQHSHHHNPHRHRHHHRHHH-EGSHHSKNENHRAPSETQ ICENMTKKADEKLAEVEPKPTGQLSHHHNLHRHRQHHHHRE--GSHHAKNENRQAPSETQ LCENITKKADEKLAEIEPKPTGQHSHHHNLHRHRQHHHHRE--GSHHSKNENHQAPSETQ ICENITKQADEKRAEIEPSPTGQRSHDHNTHRHIKHHQHRE--GSHHSKNENHQAPSETR ICENITKKADEKLAERELQPADQHSHHHDPHRHGHHHHHRE--GSHHSRNENHQALSETQ ICENITKKADEKLAEVEPKPTGQHSHHHSLHRHRHHHHHHE--SSRHSKNENHQSPSETQ VCENITKKADEKLAEIEPTPTGQHSHHHNLHRHRQHHHHRE--SSRHSKNENHQAPSETQ ICENITKKAEEKLAEIEPKPTGQHSHHHNLHRHRQHHNHRE--GSRHSKNENHQAPSETQ *:*:*: : :** :** *:.***.*.*** :**.: . .:*::***:: **:: 
grebe crane pelican hoatzin penguin emperor cormorant ibis tropicbird loon fulmar

grebe crane pelican hoatzin penguin emperor cormorant ibis tropicbird loon

fulmar

grebe crane pelican hoatzin penguin emperor cormorant ibis tropicbird loon fulmar
RHHPHS-------GHNRHDHTGS-HEQVDTVPPGESVE ISODKKLUKKGKTSCKNOLTUN RHHPHSGQHRRVFGHNRHDHTGS-HEQVDTAPPGESVEITQDKKLUKKGKNSCKNQLTUN RHHPHSGQRRRVFGRNRHDQTGN-HEQVDTVPAGESVEITQDKKLUKKGKTSCKNQLTUN RHHPRSGQRHRVSGHNRHGQTGR-DAQVDTVPPGESVEITQDKKLUKKGKTSCKNQLSUN RHHPHSGRRHRVFGHNRRDQTDDSHEQVDTVPPGESVEITQDKKLUKKGKTSCKNQLTUN RHHPHSGRRHRVFGHSRRDQADS-QEQVDSVPPGESVEITQDKKLUKKGKTSCKNQLTUN RHHSDSSQRHRAFGRNRHVQTGS-HEQVDTVPPGESVEITQDKKLUKKGKISCKNQLTUN RRHAHSSRRHRVFGRNRHDQTGS-HEQVDTVPPGESVDITQDKKLUKKGKTSCKNQLTUN RHHPHSSRRHRVFGHNTHDQTGS-HEQVDIGPPGESVEMTQDKKLUKKGKNSCKNQLTUH RHHPHSGRRHRVLGRTRHDQTGS-HEHVDTVPPGESVEITQDKKLUKKGKTSCKKQLTUN RHHPHSGRRHRVFGRNRHDQTGS-HEQVDTVPPGESVEITQDKKLUKKGKTSCKNQLTUS

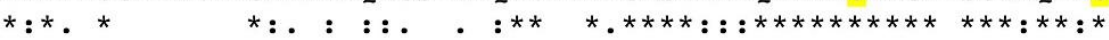

WQTASDSASSSUCCHURHLLFEELGNSVTUQCRGALPNSCRUHGQLSAEDITESUQURLL WQTASDSTSSSUCCHCRHLLFEELGNSVTUQCRGALPNSCRUHGQLSAEDITESUQURLL WQTASDSTSSSUCCHURHLLFEELGNSVTUQCRGALPNSCRUHGQLPAEDITESUQURLL WQTASDSNSSSUCCHCRHLLFEELGNSVTUQCRGALPNSCRUHGQLAAEDITESUQCRLL WQTASDPTSSSUCCHCRHLLFEELGNSVTUQCHGALPNSCSUHGQLSAEDITESUQURLL WQTASDSTSSSUCCHCRHLLFEELGNSVTUWCHGALPNSCSUHGQLSAEDITESUQURLL WQTASDSTSSSUCCHCRHLLFEELGNSVTUQCRGALPNSURUHGQLSAEDITESUQURLL WQTASDSTSSSUCCHCRHLLFEELGNSVTUQCRGALPNSCRUHGQLSAEDITESUQURLL WQTASDSASSNUCCHCRHLLFEELGNSVTUQCRGALPSSCRUHGQLSAEDITESUQURLL WQTASDLTSSSUCCHCRHLLFEELGNSVTUQCRGALPNSCRUHGQLSAEDITESUQURLL WQTASDSASSSUCCHCRHLLFEELGNSVTUQCRGALPNSCRUHGQLSAEDITESUQURLL $* * * * * * \quad * * . * * * *: * * * * * * * * * * * * * * *: * * * * . *: * * * * * . * * * * * * * * *: * * *$

TAAUQSPAAGASETSDTUQUQEKARNUAUKTN TAAUQSPAAGTSEASDTUQUQEKARNUAUKTN TAAUQSPAA--SETSDTUEUQEKARNUAUKTN TAAUQSPAAGGSETSDTUQUQENARNUAUKTN TAAUQSPAA--SETRDTUQUQEKARNUAUKTN TAAURSPAA--SETSDTUQUQEKARNUAUKTN TAAUQSPA--TSETSDTUHUQEKARNUAUKTN TAAUQSPAAGVSDSSDTUQUQEKARNUAUKTN TAAUQSPAAGATETSDTUQUQEKARNUAUKTN TAAUQSPAAGASETSDTUQUQEKARNUAUKTN TD-UQSPTAGASETSDTUQUQEKARNUAUKTN

* *:**:: : : : $* * * * * *: * * * * * * * * *$ 


\section{C}

amberjack

eel

perch

tilapia

pike

trout

salmon

zebrafish

amberjack

eel

perch

tilapia

pike

trout

salmon

zebrafish

amberjack

eel

perch

tilapia

pike

trout

salmon

zebrafish

amberjack

eel

perch

tilapia

pike

trout

salmon

zebrafish

\section{Multiple sequence alignment (fish species)}

-MWACLSLLLTLCLLHGGGAESDGDGPRCQPPPAWKIGEVDPMKEALGQVTVVALLQASU -MWACLSLLLPLCLLHGGRAESEGVGPRCQLPPAWNIGEVEPMKGTMGQVTVVALLQASC -MWRGLSLLLTLCLLHGGGAESDGGGPRCQLPPAWK IGEVEPMTQAMGRVTVLALFQASU -MWAGLSLLLTLCLLHGGGAESEGGGPRCQLPSDWRIGDVEPMKGSVGRVTVVALLQASU -MWAGLSLLLALCLLPGGGTESEGEGSRCKPPPIWS IGEVEPMKEAMGQVTVVALLQASU MMWVGLSLLLALCLLPGGGTESEGEGTRCKQPPGWS I GEVEPMKEVMGQVTVVALLQASU -MKAGLSLLLALCLLPGGGAESEGEGTRCKPPAGWS I GEVEPMKGVMGQVTVVALLQASU -MWKALSLTLALCLLVGCSAESETEGARCKLPPEWKVGDVEPMKNALGQVTVVAYLQASU

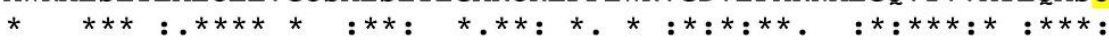

LFCLVOASRVDGLRORLESOGLKDVTYMVINHOGEEAORLHAVLAQRLSENITLYKOEEQ LFCLVQASRMDSLHQMMESQGLKNVAYMVINHQGEQAQLLHPMLAQRMSENITLYKQDQQ LFCLVOASRMDPLRNKLESOGLKNVVYMVVNHOGEHAORLHPMLADRLSENITLYKODEL LFCLVQASRLDGLQQKLERQGLKNVVYMVVNHQGEQSRHLHPLLEAKLSKNIILYKQDGH LFCLVQASLLDGLRLKLEGQGLKNVHYMVVNHQGEKAQRLHKLLKQKLSEKITLYKQEPE LFCLVQASLLDGLRLKLEGQGLENVTYMVVNHQGEQAQRLHTLLRQKLSENITLYKQQPK LFCLVQASLLDELRLKLEGQGLDNVTYMVVNHQGDQAQHLHTLLSQKLSENI ILYKQEPK LFCLEQASKLNDLLLKLEKQGYPNIAYMVVNNREERSQRLHHLLQERLLN-ITLYAQDLS $* * * * * .:: * \quad: * * * \quad:: * * *::: \quad:: * *: * \quad::: * * * *$ :

QPDVWQTLSGEKDDFLIYDRCGRLTHHISLPYS I IGQGHVEGAIKDTYCKRICGNCTHES QVDVWKTLGGQKDDFLIYDRCGRLTHH ISLPYSI IGQGHVEGAIRDTYCNRICGDCTHES QPDVWKSLNAQKDDFLIYDRCGRLTHHISLPYS I IGQGHVESAIKEAYCKRMCGDCTHES QPDVWQTLAGEKDDFF IYDRCGRLTYRISLPYS I I GEGH IEKAIKDTYCKRLCGDCTHES QVDVWQSLAGQKDDFLIYDRCGRLTYHISLPYS IMS I PYVENAIKETYCARICGNCKHES QEDVWQTLAGEKDDFLIYDRCGRLTYHISLPYS ILGTPYVENAIKETYCTRVCGDCTYES RADVWQALAGKKDDFLIYDRCGRLTHHIFLPF S ILGTPYVENAIKETYCQS ICGDCTYES QPDAWQAVNAEKDDILVYDRCGRLTYHLSLPYTILIHPHVEEAIKHTYCDRICGECSLES

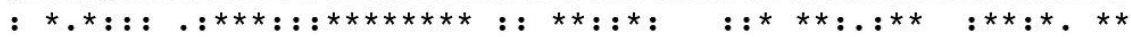

TDTPEECKGKADAQPTTDGTPAVEEDTGHGHGHGHGHGHGHGLG---HGHHHG-----TETPEECKGKADVQPDADGTPAIEHNTGHGHHHGHHHGHGHGHHGDNSGFHHG-----ADIPEECRETADAQPGADSPPAVEEGTQHGHSQDHAHGHHHRHHHHHGHGHQGDNNDFQS AEIPEECKDNAGVQPDVPAEQDDTR-HDHHHGHGHGHHHGHGHHHGHGHGHHGDNQDVHP VEIPAECNGTAEATSEGEDKPTTTVEPTHDGHOHHRHHHHHH-------HHDDKHGDHGD KEIPAECNRTVEAKPEGEEKPVTGRETTHGGHGHHHHGHGHNGNRHGHNGNRHGHDHHGE TEIPAECNRMVEVKPEGEEKPVTGGDTPHGGRGHHHHGNGHG-----HHSKSHGHGHHGE

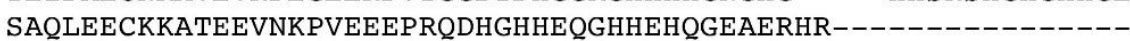
**. . $\quad$ : . : . . 
amberjack

eel

perch

tilapia

pike

trout

salmon

zebrafish

amberjack

eel

perch

tilapia

pike

trout

salmon

zebrafish

amberjack

eel

perch

tilapia

pike

trout

salmon
--HHHGHN--HGFHPRGFGHGRDHGTQGQEQ--DSGVSQGQQQAELGQMQQAVQVHLVSQ --HGHDHN--HGHHHGGDDVAGQG--HDHRQ--VGGVSQRQEHFDLGQMQQAVLTQQMLQ RGHGHHHGHHHGHHHQHHHGQSQQGVSDQGHEQDGGLSQRQPSLDLGQMQQEVHLQEMSH HGHGSDHNNGHHHRNHDGADQTQHGVRPHGHFHEGDMPQTQHHFDLGQIPQEVHNQQVAQ REVGRGHGAEQ-----QRHHKHVGEGHRHVQD-----QLHVSQDHVGQTAVQLG---QET RGMGRGHGRDHGAER-QHQHDTEGLQHGQAHG-----QLHVGQEHMGQQAVQLGQMPQEG SEVGRDHGRGHGVEQQQHQHGAEGLHHGQAHG-----QLHVGQEHMGQQ-------PKEA --HGHHHPHHHHHHHRGQQQ-------------------VDVDQQVLSQVDFGQVA .*

EANGAP-VRPUVPQKARUKSKYSUQWTAGSDNEASPKVSUCUHURRLFGEAGSKQPVGLU EAHRAP-VRPUASERARUKSKHSUQWTAGSDNEASPKISUCUHURRLFGDAGSEQPVGLU QAQAEP-SRPUVQETVRCKSKHSUQWAAGSDNEASPKASUCUHURKLFDDAGSEQPVGLU EAHAVI-ERPULSRKNRUKLKYNUQGLTGSDNEI--KSSUCUHURRLFGEAGSEQPVGLU NEGQVM-QRPUAKEGVRCSGQHDUQWKEGSVLSPSSKASUCUHURHLLDDGVSGQPIRLU QRGHIM-QNPUVKGKSRUKAEHSUQWKEGSDLSPSSKASUCUHURRLFGDGVSNEPIGLU QEGH IM-QRPUVKGRARUKAELSUHLKEGSDISPSSKVSUCUHURGLFGNGVSNEPVGLU VETPMM-KRPUAKH-SRUKVQYSUQQ--GAD---SPVASUCUHURQLFGGEGNGRVAGLU : * $\quad *: \quad: * * \quad * \quad: \quad * * * * * * *:$. . $\quad * *$

HCDKALPASUQUHGLIGDAANNVRETUQURSPPAE-UQQPQPAQUAUPPGVVS-----HCNEALPASUQUHGLIGDAASNVRETUQURTPPAD-UQQPQPNQUAUPPGVVS-----HCDEALPASUQUHGLKGDAA--VRETUQURSPPAD-UQQPQPAQUAUPPGVVS-----HCDEALPTSURUHGLIGDAVNDVRETUQURLPHAA-UQEPQPAQUAUPPGVVS-----HCNEALPASCQUHGLKG----LLRETUQURSPQTD-UQQPRPVMUAUSPGVES-----HCDEALPASUQUQGLIG-----LRETUQURSSLAD-UQQPQPVMUAUPLGVESUGUGLL HCDEALPASUQUQGLMGDSTNH IRETUQURSPPAD-UQQPPPVMSAUSPGVETUGUEQL

\section{d Multiple sequence alignment (various cetacean species)}

dolphin tursiops orca beluga porpoise cachalot lipotes

dolphin tursiops orca beluga porpoise cachalot lipotes

dolphin tursiops orca beluga porpoise cachalot lipotes

dolphin tursiops orca beluga porpoise cachalot lipotes
MNIRI IAPAMWRGLGLALALCLLPTGGTESQGQSSFCKQPPAWS IKDQDPMLNSYGSVTV MNIRMTAPAMWRGLGLALALCLLPTGGTESQGQSSFCKQPPAWS IKDQDPMLNSYGSVTV --------MWRGLGLALALCLLPTGGTESQGQSSFCKQPPAWS IKDQDPMLNSYGSVTV MNIRMTAPAMWRGLGLALALCLLPTGGTESQGQSSFCKQPPAWS IKDQDPMLNSYGSVTV --------MWRGLGLALALCLLPTGGTESQGQSSFCKQPPAWS IKDQDPMLNSYGSVTV ----MTAPAMWRGLGLALALCLLPTGGTESQGQSSFCKQPPAWS IKDQDPMLNSYGSVTV -------MWRGLGLALALCLLPTGGTESQGQSSFCKQPPAWS IKDQDPMLNSYGSVTV $\star * * * * * * * * * * * * * * * * * * * * * * * * * * * * * * * * * * * * * * * * * * * * * * * * * *$

VALLQASUYLCILQASRLEDLRVKLEKEGYSNISYVVVNHQGISSRLSYVHLKNKVSEHI VALLQASUYLCILQASRLEDLRVKLEKEGYSNISYVVVNHQGISSRLSYVHLKNKVSEHI VALLQASUYLCILQASRLEDLRVKLEKEGYSNISYVVVNHQGISSRLSYVHLKNKVSEHI VALLQASUYLCILQASRLEDLRVKLEKEGYSNISYVVVNHQGISSRLNYVHLKNKVSEHI VALLQASUYLCILQASRLEDLRVKLEKEGYSNISYVVVNHQGISSRLNYVHLKNKVSEHI VALLQASUYLCILQASRLEDLRVKLEKEGYSNISYVVVNHQGISSRLKYVHLKNKVSEHI VALLQASUYLCILQASRLEDLRVKLEKEGYSNISYVVVNHQGISSRLKYVHLKNKVSEHI $* * * * * * * * * * * * * * * * * * * * * * * * * * * * * * * * * * * * * * * * * * * * * * *, * * * * * * * * * * * *$

PVYQQEENQTDVWTLLNGNKDDFLIYDRCGRLVYHLGLPYSFLTFSYVEDSIKSVYCESK PVYQQEENQTDVWTLLNGNKDDFLIYDRCGRLVYHLGLPYSFLTFSYVEDSIKSVYCESK PVYQQEENQTDVWTLLNGNKDDFLIYDRCGRLVYHLGLPYSFLTFSYVEDSIKSVYCESK PVYQQEENQTDVWTLLNGKKDDFLIYDRCGRLVYHLGLPYSFLTFSYVEDSIKTVYCESK PVYQQEENQTDVWTLLNGKKDDFLIYDRCGRLVYHLGLPYSFLTFSYVEDSIKTVYCESK PVYQQEENQTDVWTLLNGKKDDFLIYDRCGRLVYHLGLPYSFLNFSYVEDS I KTVYCESK PVYQQEENQTDVWTLLNGKKDDFLIYDRCGRLVYHLGLPYSFLTFSYVEDSIKTVYCESK $* * * * * * * * * * * * * * * * * *: * * * * * * * * * * * * * * * * * * * * * * * *, * * * * * * * * *: * * * * * *$

CGNCSLKTLEYEDFCKNVSLATVEKTTEAPQP------HHHHHHHHHLENGHLSEYPKPE CGNCSLKTLEYEDFCKNVSLATVEKTTEAPQP------HHHHHHHHHLENGHLSEYPKPE CGNCSLKTLEYEDFCKNVSLATVEKTTEAPQPHHHHHHHHHHHHHHHLENGHLSEYPKPE CGNCSLKTLEDEDFCKNVSLATAEKTTEAPQP---HHHHHHR-----LENSHLSEYPKPE CGNCSLKTLEDEDFCKNVSLATAEKTTEAPQP---HHHHHHHHHHHHLENSHLSEYPKPE CGNCSLKTLEDEGFCKNVSLATEEKTTEAPQP--HHHHHHHHHHHHHLENGHLSEYPIPE CGNCSLKTLEDEGFCKDVSLATAEKTTEAPQP--HHHHHHHHHHHHHLENGHLSEYPKPE $* * * * * * * * * * . * * *: * * * * * * * * * * * * * * \quad * * *: \quad * * * . * * * * * * * *$ 
dolphin

tursiops

orca

beluga

porpoise

cachalot

lipotes

dolphin

tursiops

orca

beluga

porpoise

cachalot

lipotes

dolphin tursiops

orca

beluga

porpoise

cachalot

lipotes
APDNPEHPPPSGLHRHHRHRGHQRQGHSENUDALQLSFPQKKLURSGCINQLLUKFPKDS APDNPEHPPPSGLHRHHRHRGHQRQGHSENUDALQLSFPQKKLURSGCINQLLUKFPKDS APDNPEHPPPSGLHHHHRHRGHQRQGHSENUDALQLSFPQKKLURSGCINQLLUKFPKDS APDNPEHPPPSGLHRHHRHRGHQRQGHSENUDALQLSLPQKKLURSGCINQLLUKFPKDS APDNPEHAPP SGLHRHHRHRGHQRQGHSENUDALQLSLPQKKLURSGCINQLLUKFPKDS APDNPEHTPPSGLHRDHRHRGHQRQGHSENUDTLQLSLPQKKLUVRGCVNQLLUKFPRDS APDNPEHPPPSGLHHHHRHRGHQRQGHSENUDTLQISLPQKKLURSGCINQLLUKFPKDS $* * * * * * * . * * * * * *: . * * * * * * * * * * * * * * * *: * *: *: * * * * * * \quad * *: * * * * * * * *: * *$

ESALSSUUUHCRHLIFEKTGSAVTUQCKDNLPSLCSUQGLLAEEHVTESUQURLPPAACH ESALSSUUUHCRHLIFEKTGSAVTUQCKDNLPSLCSUQGLLAEEHVTESUQURLPPAACH ESALSSUUUHCRHLIFEKTGSAVTUQCKDNLPSLCSUQGLLAEEHVTESUQURLPPAACH ESALSSUCUHCRHLIFEKTGSAVTUQCKQNLPSLCSUQGLLAEEHVTESUQURLPPAACH ESALSSUCUHCRHLIFEKTGSAVTUQCKENLPSLCSUQGLLAEEHVTESUQURLPPAACH ESALSSUUUHCRHLIFEKTGSAVTUQCKENLPSLCSUQGLLAEEHVTESUQURLPRAACP ESALSSUCUHCRHLIFEKTGSAVTUQCKENLPSLCSUQGLLAEEHVTESUQURLPPAACQ

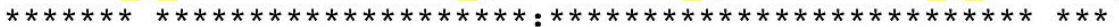

SSQQLKPTEAGTKUSUEKKAEMUKUPSD ATQQLKPTEASTKUSUEKKAEMUKUPSD ASQQLKPTEASTKUSUEKKAEMUKUPSD ASQQLKPTEASTKUSUEKKAEMUKUPSN ASQQLKPTEASTKUSUEKKAEMUKUPSN ASQQLNPTEASTKUSUKKKAEMUKUPSN ASQQPNPTEASTKUSUKKKAEMUKUPSN $:: * *: * * * * . * * * * *: * * * * * * * * * *$ :

\section{e Multiple sequence alignment (various pinniped species)}

fur seal sea lion walrus Weddell seal monk seal

fur seal sea lion walrus Weddell seal monk seal

fur seal sea lion walrus Weddell seal monk seal

fur seal sea lion walrus Weddell seal monk seal
MWRSLGLALALCLLPWGGAESQGQSSLCKPPPAWSIGDQNPMVKSSGSVTVVALLQASUY MWRSLGLALALCLLPWGGAESQGQSSFCKPPPAWSIGDQNPMVNSSGSVTVVALLQASUY MWRSLGLALALCLLPWGGAESQGQSSFCKPPPAWSIGDQNPMVNSSGSVTVVALLQASUY MWRSLGLALALCLLPWGGAESQEQSSFCKQPPAWSIGDQNPMLNSSGSVTVVSLLQASUY MWRSLGLALALCLLPWGGAESQEQSSFCKQPPAWS IGDQNPMLNSSGSVTVVALLQASUY $* * * * * * * * * * * * * * * * * * * * * * * * *: * * * * * * * * * * * * * *:: * * * * * * * *: * * * * * * *$

LCILQASRLEDLRVKLEKEGYLNISYVVVNHQGLSSQLKYMHLKNKVSEYIAVYQQEENQ LCILQASRLEDLRVKLEKEGYLNISYVVVNHQGLSSQLKYMHLKNKVSEYIAVYQQEENQ LCILQASRLEDLRIKLEKEGYLNISYVVVNHQGLSSQLKYMHLKNKVSEYIAVYQQEENQ LCILQASRLEDLRVKLEKEGYLNISYVVVNHQGLSSQLKYMHLKNKVSEYIPVYQQEENQ LCILQASRLEDLRVKLEKEGYLNISYVVVNHQGLSSQLKYMHLKNKVSEYIPVYQQEENQ $* * * * * * * * * * * * *: * * * * * * * * * * * * * * * * * * * * * * * * * * * * * * * * * * * * *, * * * * * * * *$

TDVWMLLNGKKEDFLIYDRCGRLVYHLGLPYSFLTFPYIEEAIKITYCKEKCGSCSLMTL TDVWMLLNGKKEDFLIYDRCGRLVYHLGLPYSFLTFPY IEEAIKITYCKEKCGNCSLMTL TDVWTLLNGKKEDFLIYDRCGRLVYHLGLPYSFLTFPYVEEAIKITYCKERCGSCSLTTL TDVWMLLNGKKDDFLIYDRCGRLVYHLGLPYSFLTFPYVEEAIKFTYCKEKCGHCSLMTL TDVWMLLNGKKDDFLIYDRCGRLVYHLGLPYSFLTFPYVEEAIKITYCEEKCGHCSLMTL $* * * * * * * * * *: * * * * * * * * * * * * * * * * * * * * * * * * * *: * * * * *: * * *: *: * * * * * * *$

ESEDFCKMVSSATVGNTTEAPQP---HHHHHHHHHRHHHKHGHQHHGIDGVSENQQPEAP EAEDFCKMVSLTTVGNTTEAPQPH--HHHHHHHHHCHHHKHGHQHHGIDGVSENQQPEAP EAEDFCKMVCLATVGDTTEAPQPHHHHHHHHHHHHRHHHKHGHQHHGIDGVSENQQPEAP EAADHCKMVSSATVGNTTEAPQP-----HHHHHHHGHHLKHEHQHHGIDGVSENQQPEAP EAEDHCKMVSSATVGNTTEAPQP-----HHHHHHHGHHHKHEHQHHGIDGVSENQQPEAP $*: * . * * * * .: \mathbf{x}^{*} * *: * * * * * * * \quad * * * * * * * * * * * * * * * * * * * * * * * * * * * * *$ 


fur seal
sea lion
walrus
Weddell seal
monk seal
fur seal
sea lion
walrus
Weddell seal
monk seal

fur seal
sea lion
walrus
Weddell seal
monk seal

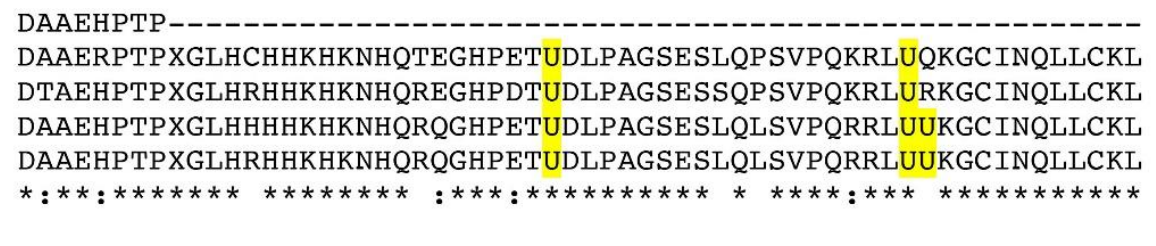

PKDSGLAPNSCCUHURHLIFEKTGSAVTUQCKESLPSLCSUQGLWAEENVIESUQURLPP PKDSGLAPNSCCUHURHLIFEKTGSAITUQCKESLPSLCSUQGLWAEENVIESUQURLPP PKDSGLAPNSCCUHURHLIFEKTGSAITUQCKETLPSLCSUQGLWAEENVIESUQURLPP PKDSGLAPNSCCUHURHLIFEKTGSAITUQCKETLPSLCSUQGLWAEENVIESUQURLPP $* * * * * * * * * * * * * * * * * * * * * * * * * *: * * * * * *: * * * * * * * * * * * * * * * * * * * * * * * * * *$

AAUQASQQLQPTEASTNUSUKHKAKM AAUQASQQLQPTEASTNUSUKHKAKM AAUQASQQLQPTEASASUSUKHKAKM AAUQASQQLQPTEASASUSUKHKAKM

Figure S13. Multiple sequence alignments of SelP proteins. Selenocysteine residues (U) are highlighted in yellow. The conserved XUXUX ${ }^{6} U X U X$ motif is present in cetaceans, birds, and mammals. This motif is also present in some fish species. The UXUX'UX $X^{7} U X U$ motif is found in many species and pinnipeds have the following motif: UXUX ${ }^{6} U X^{14} U X U$. All these motifs can form a tetraselenolate complex with $\mathrm{Hg}$. The asterisks, colon, and period denote residues that are identical, have strongly similar properties, and have weakly similar properties, respectively. GenBank access numbers are in parenthesis.

a) Homo sapiens (AAH15875.1); house mouse: Mus musculus (NP_001036079.1); great crested grebe: Podiceps cristatus (KL268852.1); zebrafish: Danio rerio (NP_840082.3).

b) great crested grebe: Podiceps cristatus (KL268852.1); grey crowned crane: Balearica regulorum gibbericeps (XP_010311294.1); Dalmatian pelican: Pelecanus crispus (XP_009484102.1); Adélie penguin: Pygoscelis adeliae (XP_009322697.1); emperor penguin: Aptenodytes forsteri (XP_009272808.2); great cormorant: Phalacrocorax carbo (XP_009511852.1); crested ibis: Nipponia nippon (XP_009472359.1); white-tailed tropicbird: Phaethon lepturus (XP_010284851.1); redthroated loon: Gavia stellata (XP_009818154.1); Arctic fulmar: Fulmarus glacialis (XP_009579693.1).

c) greater amberjack: Seriola dumerili (XP_022613554.1); swamp eel: Monopterus albus (XP_020449352.1); climbing perch: Anabas testudineus (XP_026199022.1); Nile tilapia: Oreochromis niloticus (XP_013127321.2); northern pike : Esox lucius (XP_012992107.1); rainbow trout: Oncorhynchus mykiss (CCX35038.1); Atlantic salmon: Salmo salar (AXS67852.2); zebrafish: Danio rerio (NP_840082.3).

d) Pacific white-sided dolphin: Lagenorhynchus obliquidens (XP_026956984.1); common bottlenose dolphin: Tursiops truncatus (XP_019785640.1); killer whale: Orcinus orca (XP_004266005.2); beluga whale: Delphinapterus leucas (XP_022453898.1); narrow-ridged finless porpoise: Neophocaena asiaeorientalis (XP_024596120.1); sperm whale: Physeter catodon (XP_007119423.2); Yangtze River dolphin: Lipotes vexillifer (XP_007447694.1).

e) northern fur seal: Callorhinus ursinus (XP_025723121.1); California sea lion: Zalophus californianus (XP_027460417.1); Pacific walrus: Odobenus rosmarus divergens (XP_004409206.2); 
Weddell seal: Leptonychotes weddellii (XP_006747601.1); monk seal: Neomonachus schauinslandi (XP_021556282.1).

\begin{abstract}
MWKALSLTLALCLLVGCSAESETEGARCKLPPEWKVGDVEPMKNALGQVTVVAY LQASULFCLEQASKLNDLLLKLEKQGYPNIAYMVVNNREERSQRLHHLLQERLLNI TLYAQDLSQPDAWQAVNAEKDDILVYDRCGRLTYHLSLPYTILIHPHVEEAIKHTYC DRICGECSLESSAQLEECKKATEEVNKPVEEEPRQDHGHHEQGHHEHQGEAER HRHGHHHPHHHHHHHRGQQQVDVDQQVLSQVDFGQVAVETPMMKRPUAKHS RUKVQYSUQQGADSPVASUCUHURQLFGGEGNGRVAGLUHCDEPLPASUPUQ GLKEQDNHIKETUQURPAPPAEUELSQPTUVUPAGDATUGURKK
\end{abstract}

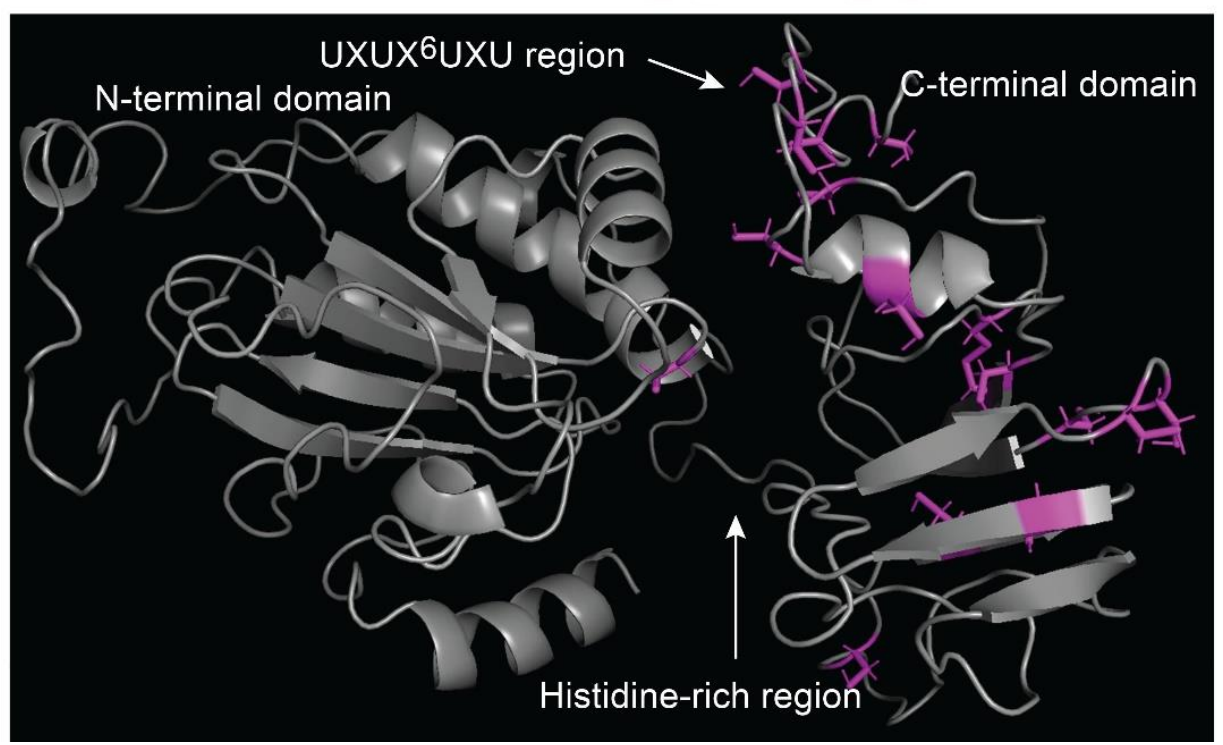

Figure S14. Predicted tertiary structure from I-Tasser ${ }^{43,44}$ of SelP for zebrafish. SelP is made up of a $\mathrm{N}$-terminal domain containing $1 \mathrm{Sec}$ residue (U) and a C-terminal domain containing $16 \mathrm{U}$ residues in zebrafish (and $13 \mathrm{U}$ residues in the grebe). The two domains are connected through a histidine-rich region. The N-terminal domain has redox enzymatic properties and the C-terminal domain supplies Se to extrahepatic tissues ${ }^{45}$. The 17 side chains from the Sec residues in the two domains are represented by purple squares on the left side of the figure. The figure on the right side presents the C-terminal domain. Only the $6 \mathrm{Sec}$ side chains located on the flexible loop after the $\alpha$-helix are represented. The position of these residues in the amino acid sequence, represented in single-letter code, is denoted with a $\underline{\mathrm{U}}$ symbol. The structures were visualized with $\mathrm{PyMol}^{46}$. 

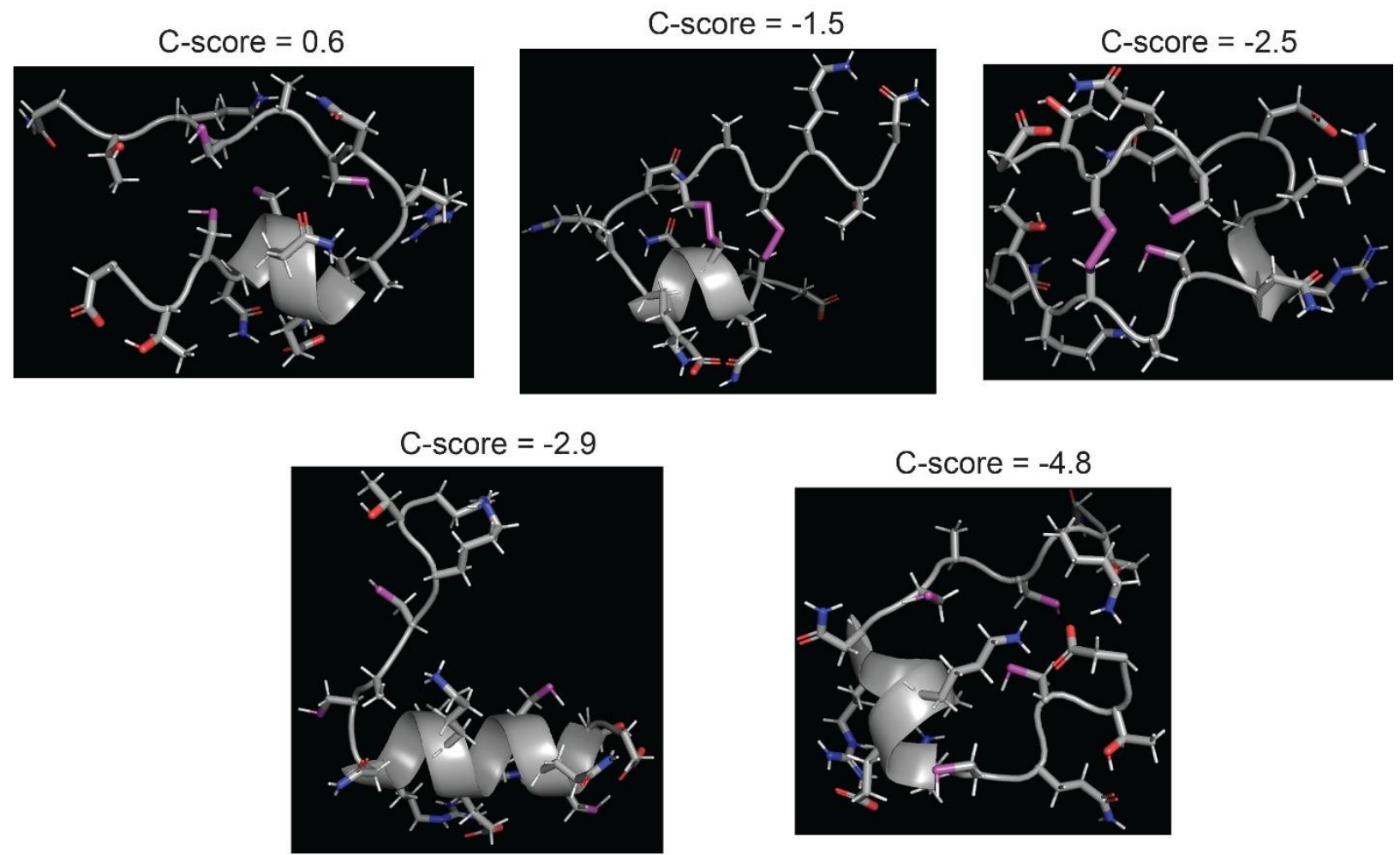

b

Zebrafish PTUVUPAGDATUGURKK
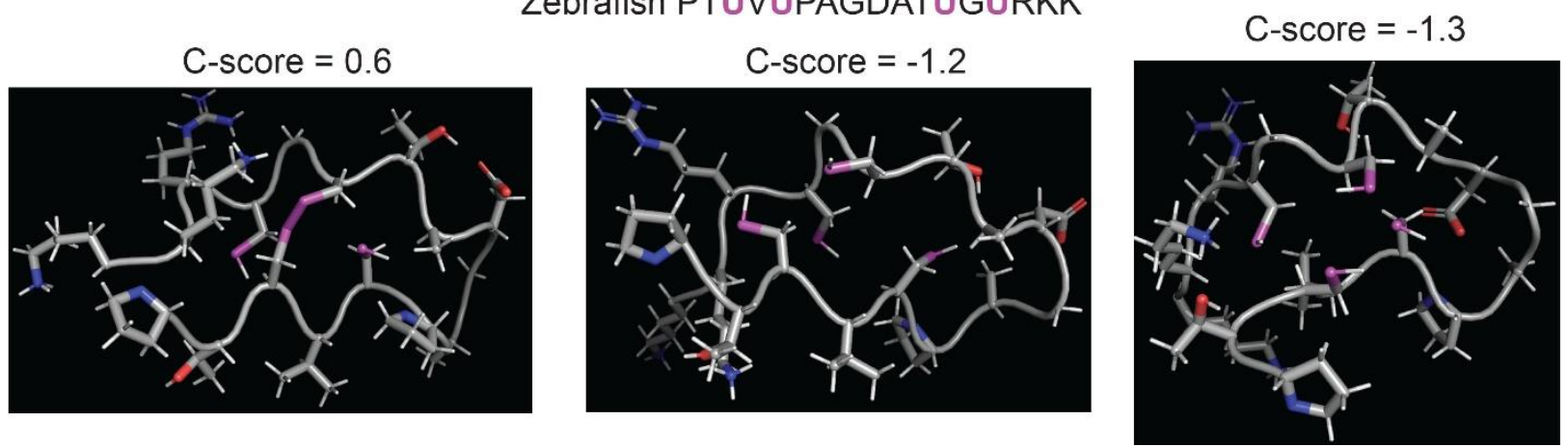

Figure S15. Tertiary structure of the UXUX $X^{6} U X U$ region of the C-terminal domain of SelP for the great crested grebe and zebrafish generated by I-Tasser ${ }^{43,44}$. I-Tasser ranks predicted models according to the $\mathrm{C}$-score confidence parameter and the cluster size. a) Top five predicted models for the great crested grebe. The Sec residues of the three highest C-score models form a cage conducive to binding $\mathrm{Hg}$. Some of the Sec residues are linked through Sec-Sec bridges. b) I-Tasser listed only three models of zebrafish because the top homologous structure templates were similar to each other. This means that the simulation is well converged, thus the structure prediction is of high quality. All conformations were modeled on cysteine-substituted sequences. The amino-acids in each sequence are represented with a single-letter code, with $\mathrm{U}$ corresponding to selenocysteine. Purple, red, and blue represent selenol, carboxyl/hydroxyl, and amino groups from amino-acid side chains, respectively. 


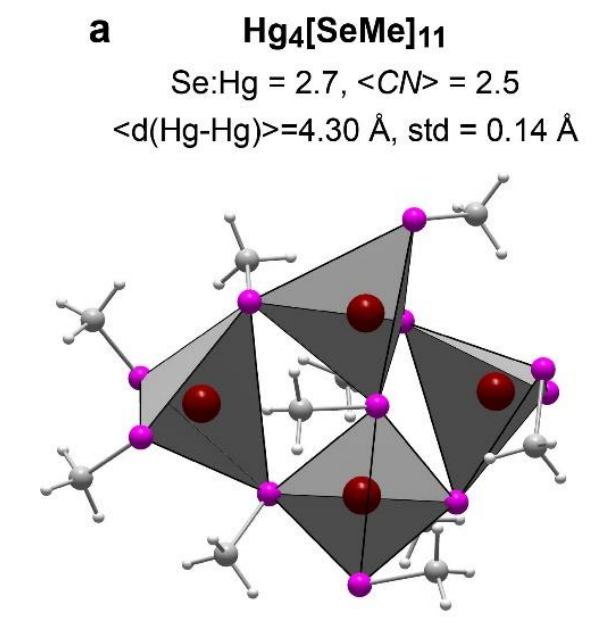

$$
\begin{gathered}
\text { b } \mathrm{Hg}_{4}[\mathrm{SeMe}]_{12} \\
\mathrm{Se}: \mathrm{Hg}=3.0,<C N>=2.0 \\
<\mathrm{d}(\mathrm{Hg}-\mathrm{Hg})>=4.62 \AA, \mathrm{std}=0.11 \AA
\end{gathered}
$$
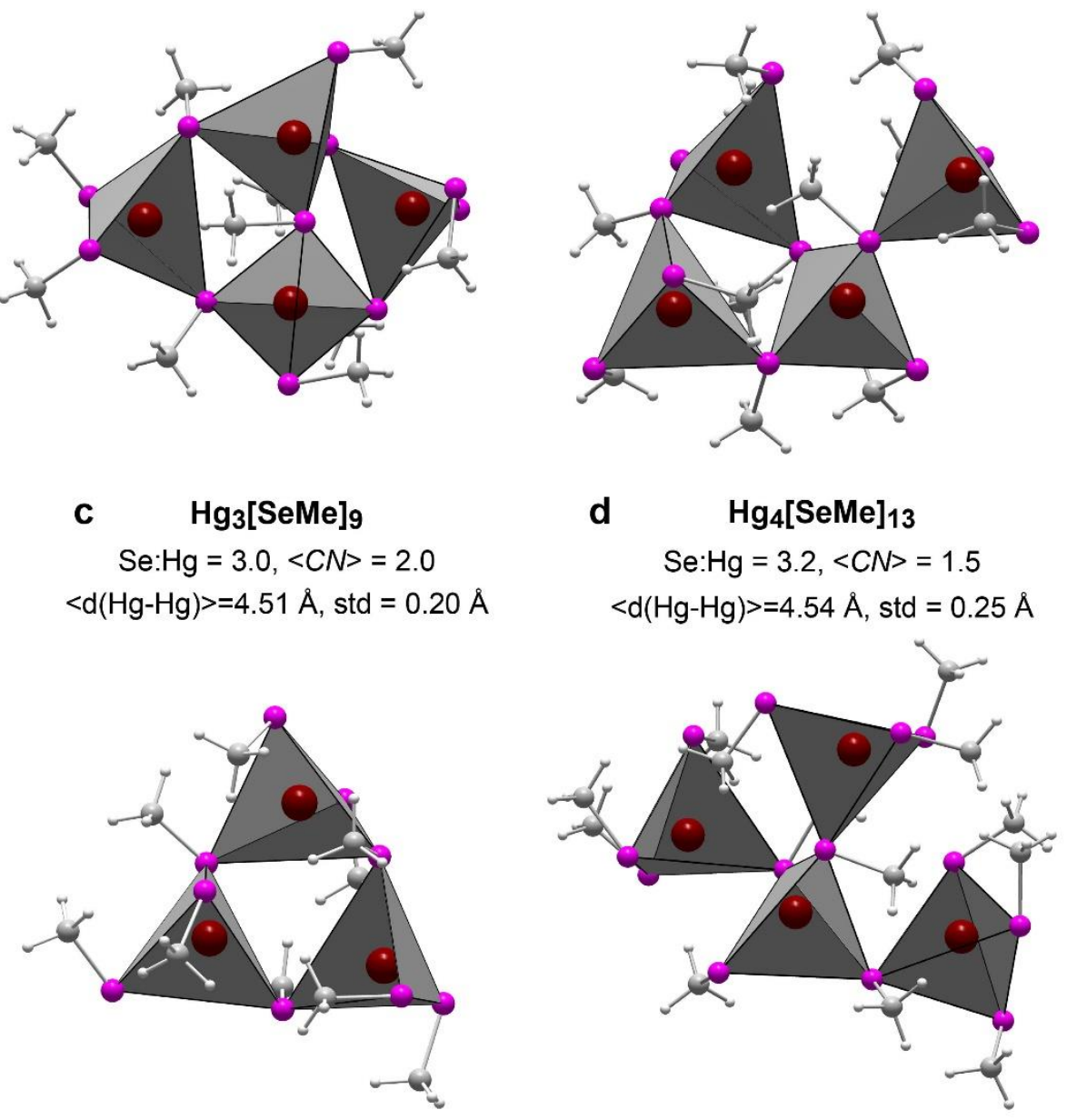

Figure S16. Theoretical topologies of $\operatorname{Hg}_{\mathrm{x}}(\mathrm{Se}, \mathrm{Sec})_{\mathrm{y}}$ clusters inspired from metallothionein metal clusters with average $\mathrm{Hg}-\mathrm{Hg}$ coordination numbers $(\langle C N\rangle)$ and distances $(\langle\mathrm{d}(\mathrm{Hg}-\mathrm{Hg})\rangle) . \mathrm{a}) \mathrm{Hg}_{4}(\mathrm{Sec})_{11}$ cluster inspired from the $\alpha-(\mathrm{Zn}, \mathrm{Cd})_{4}(\mathrm{Cys})_{11}$ cluster of metallothionein in vertebrate ${ }^{47}$. b) $\mathrm{Hg}_{4}(\mathrm{Sec})_{12}$ cluster inspired from the $\mathrm{Cd}_{4}(\mathrm{Cys})_{12}-\alpha$ cluster of the metallothionein for Mytilus galloprovincialis ${ }^{48}$. c,d) $\mathrm{Hg}_{3}(\mathrm{Sec})_{9}$ and $\mathrm{Hg}_{4}(\mathrm{Sec})_{13}$ clusters inspired from the $(\mathrm{Zn}, \mathrm{Cd})_{\mathrm{x}}(\mathrm{Cys})_{\mathrm{y}}$ clusters in bacterial metallothionein ${ }^{49}$. The $\mathrm{Hg}$ atom adopts tetrahedral tetraselenolate coordination geometry in all clusters, but the connectivity varies. The Se:Hg ratio can be diminished by substituting a Cys for a Sec ligand. Note that the C-terminal domain of SelP has one Cys residue (Figure S14). Because Hg has an affinity for Se that is approximately two order of magnitude higher than for sulfur ${ }^{50}$, the thiol ligand of $\mathrm{MeHgCys}$ complexed at the surface of $\mathrm{a} \mathrm{Hg}_{\mathrm{x}}(\mathrm{Se}, \mathrm{Sec})_{\mathrm{y}}$ cluster can be replaced with a selenolate ligand, catalyzing the demethylation of $\mathrm{MeHg}$ and promoting the growth of the clusters. All clusters were optimized geometrically at the PBE0-D3 DFT quantum level with def2-TZVP ( Hg, Se) and def2-SVP $(\mathrm{C}, \mathrm{H})$ basis sets using ORCA 4.2.1 ${ }^{31}$. The water solvent was represented with the SMD model ${ }^{38}$. Sec residues were modeled with methaneselenolate $\left(\mathrm{CH}_{3} \mathrm{Se}^{-}\right)$. Dark red, $\mathrm{Hg}$; purple, Se; gray, C, light gray, H. 

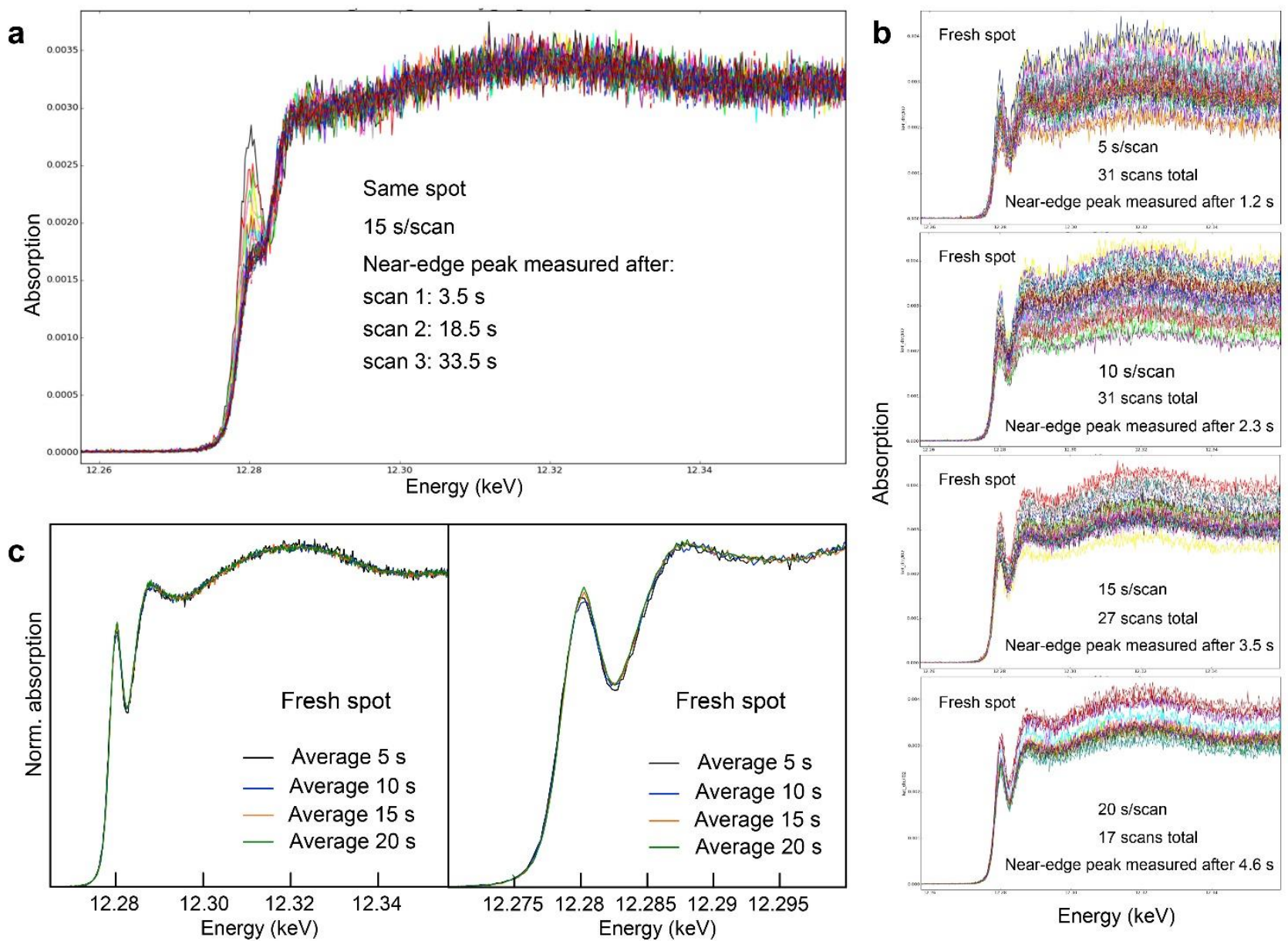

Figure S17. Tests of beam damage. a) The near-edge peak of $\mathrm{MeHgCys,} \mathrm{which} \mathrm{corresponds} \mathrm{to}$ transitions of the $\mathrm{Hg} 2 \mathrm{p}_{3 / 2}$ photoelectron to hybridized $\mathrm{Hg} 6 \mathrm{~s} 5 \mathrm{~d}-\mathrm{S} 3 \mathrm{sp}$ bound-states from the $\mathrm{Hg}-\mathrm{S}$ bond and to hybridized $\mathrm{Hg} 6 \mathrm{~s} 5 \mathrm{~d}-\mathrm{C} 2 \mathrm{sp}$ bound-states from the $\mathrm{Hg}-\mathrm{C}$ bond ${ }^{32}$, decreases in intensity after $18.5 \mathrm{~s}$ of exposure, and even more so at longer exposure time. The other regions of the HRXANES spectrum appear stable. In this test, the near-edge peak was first measured (1st scan) after 3.5 $\mathrm{s}$ of sample illumination, a duration perhaps already too long to prevent any radiation damage. This possibility was tested next by measuring multiple scans of $5 \mathrm{~s}, 10 \mathrm{~s}, 15 \mathrm{~s}$, and 20, each on a fresh spot (b). In this test, the near-edge peak was always measured after $1.2 \mathrm{~s}$ ( $5 \mathrm{~s}$ scan), $2.3 \mathrm{~s}$ (10 s scan), $3.5 \mathrm{~s}$ (15 s scan), and $4.6 \mathrm{~s}$ (20 s scan) of exposure time. Then each scan series was summed up and normalized to unit step, and the four spectra compared to one another (c). Careful evaluation of spectra in $\mathbf{c}$ shows that the near-edge peak is statistically invariant. We conclude that the samples did not suffer any detectable radiation damage over the $15 \mathrm{~s}$ dwell time of all measurements. Furthermore, radiation damage decreases the amplitude of the HR-XANES peaks without changing their energy position, as shown previously in Figure S4 from Ref. ${ }^{29}$. Plots (a) and (b) are screenshots from the PyMCA software ${ }^{51}$. 


\section{S3. Supplementary tables}

Table S1. Body weight, size, and length of fish

\begin{tabular}{|c|c|c|c|}
\hline Individual & Genus and species & Weight $(\mathrm{g})$ & Body size $(\mathrm{cm})^{a}$ \\
\hline PeacockBass-1 & Cichla monoculus & 356 & 24.3 \\
\hline PeacockBass-2 & Cichla temensis & 284 & 24.0 \\
\hline PeacockBass- 3 & Cichla temensis & 304 & 25.5 \\
\hline Pescada-1 & Plagioscion squamosissimus & 225 & 28.5 \\
\hline Pescada-2 & Plagioscion squamosissimus & 190 & 27.8 \\
\hline
\end{tabular}

${ }^{\bar{a}}$ Excluding the caudal fin. 
Table S2. Total concentrations of $\mathrm{Hg}$ and Se determined by chemical analysis $\left(\mathrm{mg} \mathrm{kg}^{-1}\right)$ and proportions of organic (MeHgCys) and inorganic $\left(\mathrm{Hg}(\mathrm{Sec})_{4}\right.$ and $\left.\mathrm{Hg}(\mathrm{SR})_{2}\right) \mathrm{Hg}$ determined by $\mathrm{HR}$-XANES in fish

\begin{tabular}{|c|c|c|c|c|c|c|c|c|}
\hline Individual and tissue $^{a}$ & Genus and species & $\begin{array}{l}{[\mathrm{Hg}]_{\mathrm{Tot}}} \\
\mathrm{mg} \mathrm{kg}^{-1}\end{array}$ & $\begin{array}{c}{[\mathrm{Se}]_{\mathrm{Tot}}} \\
\mathrm{mg} \mathrm{kg}^{-1}\end{array}$ & $\% \mathrm{MeHgCys}$ & $\% \mathrm{Hg}(\mathrm{Sec})_{4}$ & $\% \mathrm{Hg}(\mathrm{SR})_{2}$ & $\%$ Precision & $N S S \times 10^{-5}$ \\
\hline PeacockBass-1-M & Cichla monoculus & $2.8 \pm 0.3$ & $0.82 \pm 0.08$ & 100 & 0 & 0 & 5 & - \\
\hline PeacockBass-1-L & Cichla monoculus & $1.2 \pm 0.1$ & $3.79 \pm 0.38$ & 86 & 14 & 0 & 10 & 14.8 \\
\hline PeacockBass-2-M & Cichla temensis & $1.1 \pm 0.1$ & $1.06 \pm 0.11$ & 100 & 0 & 0 & 5 & - \\
\hline PeacockBass-2-L & Cichla temensis & $1.7 \pm 0.2$ & $7.13 \pm 0.71$ & 46 & 39 & 16 & 10 & 6.1 \\
\hline PeacockBass-3-M & Cichla temensis & $3.1 \pm 0.3$ & $1.01 \pm 0.10$ & 100 & 0 & 0 & 5 & - \\
\hline PeacockBass-3-L & Cichla temensis & $5.5 \pm 0.5$ & $9.44 \pm 0.94$ & 38 & 62 & 0 & 5 & 3.2 \\
\hline Pescada-1-M & Plagioscion squamosissimus & $3.2 \pm 0.3$ & $0.81 \pm 0.08$ & 100 & 0 & 0 & 5 & - \\
\hline Pescada-1-L & Plagioscion squamosissimus & $1.4 \pm 0.1$ & $1.59 \pm 0.16$ & 91 & 9 & 0 & 10 & 19.5 \\
\hline Pescada-2-M & Plagioscion squamosissimus & $4.0 \pm 0.4$ & $1.10 \pm 0.11$ & 100 & 0 & 0 & 5 & - \\
\hline Pescada-2-L & Plagioscion squamosissimus & $2.0 \pm 0.2$ & $2.75 \pm 0.27$ & 85 & 15 & 0 & 7 & 9.5 \\
\hline
\end{tabular}

${ }^{a} \mathrm{M}$ denotes muscle tissue and $\mathrm{L}$ denotes liver tissue.

Table S3. Total concentrations of $\mathrm{Hg}$ and Se determined by chemical analysis $\left(\mathrm{mg} \mathrm{kg}^{-1}\right)$ and proportions of organic (MeHgCys) and inorganic $\left(\mathrm{Hg}(\mathrm{Sec})_{4}\right.$ and $\left.\mathrm{Hg}(\mathrm{SR})_{2}\right) \mathrm{Hg}$ determined by $\mathrm{HR}$-XANES in earthworms

\begin{tabular}{|c|c|c|c|c|c|c|c|c|}
\hline Individual & $\begin{array}{l}\text { Sampling } \\
\text { site }\end{array}$ & $\begin{array}{l}{[\mathrm{Hg}]_{\mathrm{Tot}}} \\
\mathrm{mg} \mathrm{kg}^{-1}\end{array}$ & $\begin{array}{c}{[\mathrm{Se}]_{\mathrm{Tot}}} \\
\mathrm{mg} \mathrm{kg}^{-1}\end{array}$ & $\% \mathrm{MeHgSR}$ & $\% \mathrm{Hg}(\mathrm{Sec})_{4}$ & $\% \mathrm{Hg}(\mathrm{SR})_{2}$ & $\%$ Precision & $N S S \times 10^{-5}$ \\
\hline EarthW-endo-1 ${ }^{a}$ & S1 & $1.5 \pm 0.2$ & $7.51 \pm 0.75$ & 25 & 39 & 36 & 10 & 17.6 \\
\hline EarthW-endo-2 & $\mathrm{S} 1$ & $2.4 \pm 0.2$ & $7.93 \pm 0.79$ & 33 & 32 & 34 & 10 & 20.3 \\
\hline EarthW-endo-3 & $\mathrm{S} 1$ & $1.8 \pm 0.2$ & $8.58 \pm 0.86$ & 17 & 10 & 73 & 10 & 10.2 \\
\hline EarthW-endo-4 & $\mathrm{S} 1$ & $2.0 \pm 0.2$ & $6.76 \pm 0.68$ & 30 & 50 & 19 & 10 & 18.7 \\
\hline EarthW-endo-5 & $\mathrm{S} 1$ & $3.1 \pm 0.3$ & $4.77 \pm 0.48$ & 25 & 45 & 28 & 10 & 12.2 \\
\hline EarthW-endo-6 & $\mathrm{S} 2$ & $4.3 \pm 0.4$ & $11.7 \pm 1.2$ & 46 & 39 & 15 & 10 & 10.7 \\
\hline EarthW-endo-7 & $\mathrm{S} 2$ & $4.2 \pm 0.4$ & $5.88 \pm 0.59$ & 30 & 43 & 27 & 10 & 7.3 \\
\hline EarthW-endo-8 & $\mathrm{S} 2$ & $5.1 \pm 0.5$ & $28.3 \pm 2.8$ & 39 & 25 & 36 & 10 & 14.7 \\
\hline EarthW-endo-9 ${ }^{a}$ & $\mathrm{~S} 2$ & $5.4 \pm 0.5$ & $26.0 \pm 2.6$ & 49 & 51 & 0 & 10 & 6.0 \\
\hline EarthW-endo-10 & $\mathrm{S} 2$ & $10.1 \pm 1.0$ & $11.8 \pm 1.2$ & 50 & 50 & 0 & 10 & 9.1 \\
\hline EarthW-anecic- ${ }^{a}$ & $\mathrm{~S} 2$ & $1.2 \pm 0.1$ & $1.00 \pm 0.10$ & 60 & 29 & 10 & 10 & 12.4 \\
\hline
\end{tabular}




\begin{tabular}{lllllllll} 
EarthW-anecic-2 & $\mathrm{S} 1$ & $1.8 \pm 0.2$ & $12.7 \pm 1.3$ & 28 & 72 & 0 & 10 & 5.6 \\
EarthW-anecic-3 & $\mathrm{S} 2$ & $5.6 \pm 0.6$ & $5.19 \pm 0.52$ & 42 & 44 & 13 & 10 & 7.3 \\
\hline
\end{tabular}

${ }^{a}$ Digestive tract removed.

Table S4. Structural parameters of the Clark's grebe liver derived from Fourier-filtered Hg L3-edge HR-EXAFS analysis

\begin{tabular}{|c|c|c|c|c|c|c|c|c|c|c|c|}
\hline & \multicolumn{3}{|c|}{$\mathrm{Hg}-\mathrm{Se}$} & \multicolumn{3}{|c|}{$\mathrm{Hg}-\mathrm{S}$} & \multicolumn{3}{|c|}{$\mathrm{Hg}-\mathrm{Hg}$} & \multirow[b]{2}{*}{$\Delta E_{0}(\mathrm{eV})$} & \multirow[b]{2}{*}{ Res } \\
\hline & $R(\AA)$ & $C N$ & $\sigma^{2}(\AA)$ & $R(\AA)$ & $C N$ & $\sigma^{2}(\AA)$ & $R(\AA)$ & $C N$ & $\sigma^{2}\left(\AA^{2}\right)$ & & \\
\hline Grebe liver & 2.61 & 2.6 & $0.008^{a}$ & 2.36 & 0.8 & $0.008^{a}$ & 4.46 & 2.1 & $0.01^{b}$ & 4.6 & $5.6^{c}$ \\
\hline Confidence $^{d}$ & 0.008 & 0.6 & 0.0001 & 0.026 & 0.2 & 0.0001 & 0.029 & 0.5 & - & 1.6 & - \\
\hline
\end{tabular}

${ }^{a}$ Parameters constrained to decrease correlations between $\sigma(\mathrm{Se}, \mathrm{S})$ and $C N(\mathrm{Se}, \mathrm{S}) .{ }^{b}$ Value fixed to suppress the correlation between $\sigma(\mathrm{Hg})$ and $C N(\mathrm{Hg}) .{ }^{c} \operatorname{Res}=[\Sigma(\mid \chi$

$\left.\exp -\chi_{\text {fit }}\right) / \Sigma\left(\left|\chi_{\text {exp }}\right|\right] \times 100 .{ }^{d}$ Confidence limits of fitting parameters determined from the variation of the fit residual (Res) within $95 \%$.

Table S5. Total concentrations of $\mathrm{Hg}$ and Se determined by chemical analysis $\left(\mathrm{mg} \mathrm{kg}^{-1}\right)$ and proportions of organic (MeHgCys) and inorganic $\left(\mathrm{Hg}(\mathrm{Sec})_{4}\right.$ and $\left.\mathrm{Hg}(\mathrm{SR})_{2}\right) \mathrm{Hg}$ determined by HR-XANES in Clark's grebe

\begin{tabular}{lccccccc}
\hline Tissue & $\begin{array}{c}{[\mathrm{Hg}]_{\text {Tot }} \mathrm{mg}} \\
\mathrm{kg}^{-1}\end{array}$ & $\begin{array}{c}{[\mathrm{Se}]_{\text {Tot }}} \\
\mathrm{mg} \mathrm{kg}^{-1}\end{array}$ & $\% \mathrm{MeHgCys}$ & $\% \mathrm{Hg}(\mathrm{Sec})_{4}$ & $\% \mathrm{Hg}(\mathrm{SR})_{2}$ & $\%$ Precision & NSS x $10^{-5}$ \\
\hline Head feather & - & - & 100 & 0 & 0 & 5 & - \\
Breast feather & $40.7 \pm 4.1$ & $1.04 \pm 0.10$ & 100 & 0 & 0 & 5 & - \\
Brain & $3.1 \pm 0.3$ & $1.55 \pm 0.16$ & 100 & 0 & 0 & 5 & - \\
Muscle & $6.5 \pm 0.7$ & $2.31 \pm 0.23$ & 66 & 11 & 23 & 5 & 1.1 \\
Kidneys & $21.6 \pm 2.2$ & $10.6 \pm 1.0$ & 28 & 59 & 12 & 5 & 1.9 \\
Liver & $43.1 \pm 4.3$ & $19.3 \pm 1.93$ & 14 & 86 & 0 & 5 & 2.4 \\
\hline
\end{tabular}


Table S6. Sequences of the oligonucleotides used for PCR amplification

\begin{tabular}{lll}
\hline Primers & $5^{\prime} \rightarrow 3^{\prime}$ sequences & References \\
\hline hgcA-F & GGNRTYAAYRTNTGGTGYGC & Ref. $^{7}$ \\
hgcA-912R & GGTGTAGGGGGTGCAGCCSGTRWARKT & Ref. $^{6}$ \\
\hline
\end{tabular}

Table S7. Concentrations of MeHg as determined by HR-XANES and chemical analysis (mg Hg kg-1 dry weight)

\begin{tabular}{|c|c|c|c|c|}
\hline Individual & $\begin{array}{c}{[\mathrm{MeHgCys}]} \\
\text { XANES }^{a}\end{array}$ & Precision & $\begin{array}{l}\text { [MeHg] } \\
\text { chemical } \\
\text { analysis }\end{array}$ & Precision \\
\hline \multicolumn{5}{|l|}{ Clark's grebe } \\
\hline Head feather & - & - & - & - \\
\hline Breast feather & 40.7 & 4.6 & 34.2 & 3.4 \\
\hline Brain & 3.1 & 0.3 & 2.9 & 0.3 \\
\hline Muscle & 4.3 & 0.5 & 3.7 & 0.4 \\
\hline Kidneys & 6.0 & 1.2 & 6.4 & 0.6 \\
\hline Liver & 6.0 & 2.2 & 7.9 & 0.8 \\
\hline \multicolumn{5}{|l|}{ Fish } \\
\hline PeacockBass-1-M & 2.8 & 0.3 & 2.0 & 0.2 \\
\hline PeacockBass-1-L & 1.0 & 0.2 & 0.85 & 0.08 \\
\hline PeacockBass-2-M & 1.1 & 0.1 & 0.81 & 0.08 \\
\hline PeacockBass-2-L & 0.8 & 0.19 & 0.45 & 0.04 \\
\hline PeacockBass-3-M & 3.1 & 0.3 & 2.2 & 0.2 \\
\hline PeacockBass-3-L & 2.1 & 0.3 & 1.8 & 0.2 \\
\hline Pescada-1-M & 3.2 & 0.3 & 2.4 & 0.2 \\
\hline Pescada-1-L & 1.3 & 0.2 & 0.87 & 0.09 \\
\hline Pescada-2-M & 4.0 & 0.4 & 3.0 & 0.3 \\
\hline Pescada-2-L & 1.7 & 0.2 & 1.5 & 0.1 \\
\hline \multicolumn{5}{|l|}{ Earthworm } \\
\hline EarthW-endo-1 & 0.38 & 0.16 & 0.10 & 0.01 \\
\hline EarthW-endo-2 & 0.79 & 0.25 & 0.32 & 0.03 \\
\hline EarthW-endo-3 & 0.31 & 0.18 & 0.05 & 0.01 \\
\hline EarthW-endo-4 & 0.60 & 0.21 & 0.07 & 0.01 \\
\hline EarthW-endo-5 & 0.78 & 0.32 & 0.14 & 0.01 \\
\hline EarthW-endo-6 & 2.0 & 0.5 & 1.0 & 0.1 \\
\hline EarthW-endo-7 & 1.3 & 0.4 & 0.80 & 0.08 \\
\hline EarthW-endo-8 & 2.0 & 0.6 & 1.3 & 0.1 \\
\hline EarthW-endo-9 & 2.6 & 0.5 & 1.9 & 0.2 \\
\hline EarthW-endo-10 & 5.1 & 1.1 & - & - \\
\hline EarthW-anecic-1 & 0.72 & 0.14 & 0.39 & 0.04 \\
\hline EarthW-anecic-2 & 0.50 & 0.19 & 0.14 & 0.01 \\
\hline EarthW-anecic-3 & 2.3 & 0.6 & 1.3 & 0.1 \\
\hline
\end{tabular}




\section{S4. Supplementary references}

(1) Ackerman, J. T.; Eagles-Smith, C. A.; Herzog, M. P.; Hartman, C. A.; Peterson, S. H.; Evers, D. C.; Jackson, A. K.; Elliott, J. E.; Vander Pol, S. S.; Bryan, C. E. Avian mercury exposure and toxicological risk across western North America: A synthesis. Sci. Tot. Environ. 2016, 568, 749-769.

(2) Kleckner, A. E.; Kakouros, E.; Stewart, A. R. A practical method for the determination of total selenium in environmental samples using isotope dilution-hydride generation-inductively coupled plasma-mass spectrometry. Limnol. Oceanogr.-Meth. 2017, 15, 363-371.

(3) Gajdosechova, Z.; Mester, Z.; Feldmann, J.; Krupp, E. M. The role of selenium in mercury toxicity - Current analytical techniques and future trends in analysis of selenium and mercury interactions in biological matrices. Trac-Trend. Anal. Chem. 2018, 104, 95-109.

(4) Byun, M. O. K.; Kaper, J. B.; Ingram, L. O. Construction of a new vector for the expression of foreign genes in Zymomonas mobilis. J. Ind. Microbiol. 1986, 1, 9-15.

(5) Parks, J. M.; Johs, A.; Podar, M.; Bridou, R.; Hurt, R. A.; Smith, S. D.; Tomanicek, S. J.; Qian, Y.; Brown, S. D.; Brandt, C. C.; Palumbo, A. V.; Smith, J. C.; Wall, J. D.; Elias, D. A.; Liang, L. Y. The genetic basis for bacterial mercury methylation. Science 2013, 339, 1332-1335.

(6) Schaefer, J. K.; Kronberg, R. M.; Morel, F. M. M.; Skyllberg, U. Detection of a key Hg methylation gene, hgcA, in wetland soils. Env. Microbiol. Rep. 2014, 441-447.

(7) Bae, H. S.; Dierberg, F. E.; Ogram, A. Syntrophs dominate sequences associated with the mercury methylation-related gene $h g c A$ in the water conservation areas of the Florida Everglades. Appl. Environ. Microb. 2014, 80, 6517-6526.

(8) Liu, Y. R.; Yu, R. Q.; Zheng, Y. M.; He, J. Z. Analysis of the microbial community structure by monitoring an $\mathrm{Hg}$ methylation gene $(h g c A)$ in paddy soils along an $\mathrm{Hg}$ gradient. Appl. Environ. Microb. 2014, 80, 2874-2879.

(9) George, G. N.; Pickering, I. J.; Pushie, M. J.; Nienaber, K.; Hackett, M. J.; Ascone, I.; Hedman, B.; Hodgson, K. O.; Aitken, J. B.; Levina, A.; Glover, C.; Lay, P. A. X-ray-induced photo-chemistry and X-ray absorption spectroscopy of biological samples. J. Synchrotron Radiat. 2012, 19, 875-886.

(10) Manceau, A.; Bustamante, P.; Haouz, A.; Bourdineaud, J. P.; Gonzalez-Rey, M.; Geertsen, V.; Barruet, E.; Rovezzi, M.; Glatzel, P.; Pin, S. Mercury(II) binding to metallothionein in Mytilus edulis revealed by high energy-resolution XANES spectroscopy. Chem-Eur J. 2019, 25, 997-1009.

(11) Rovezzi, M.; Lapras, C.; Manceau, A.; Glatzel, P.; Verbeni, R. High energy-resolution x-ray spectroscopy at ultra-high dilution with spherically bent crystal analyzers of 0.5 m radius. Rev. Sci. Instr. 2017, 88, 013108.

(12) Manceau, A.; Marcus, M. A.; Tamura, N. Quantitative speciation of heavy metals in soils and sediments by synchrotron X-ray techniques. In Applications of Synchrotron Radiation in LowTemperature Geochemistry and Environmental Science, Fenter, P. A.; Rivers, M. L.; Sturchio, N. C.; Sutton, S. R., Eds. Mineralogical Society of America: Washington, DC, 2002; Vol. 49, pp 341-428.

(13) Manceau, A.; Marcus, M.; Lenoir, T. Estimating the number of pure chemical components in a mixture by X-ray absorption spectroscopy. J. Synchrotron Radiat. 2014, 21, 1140-1147.

(14) Rossberg, A.; Reich, T.; Bernhard, G. Complexation of uranium(VI) with protocatechuic acidapplication of iterative transformation factor analysis to EXAFS spectroscopy. Anal. Bioanal. Chem. 2003, 376, 631-638.

(15) Malinowski, E. R. Theory of error for target factor-analysis with applications to massspectrometry and nuclear magnetic-resonance spectrometry. Anal. Chim. Acta-Comp. 1978, 2, 339354.

(16) Mah, V.; Jalilehvand, F. Glutathione complex formation with mercury(II) in aqueous solution at physiological pH. Chem. Res. Toxicol. 2010, 23, 1815-1823.

(17) Manceau, A.; Wang, J.; Rovezzi, M.; Glatzel, P.; Feng, X. Biogenesis of mercury-sulfur nanoparticles in plant leaves from atmospheric gaseous mercury. Environ. Sci. Technol. 2018, 52, 3935-3948.

(18) Bourdineaud, J. P.; Gonzalez-Rey, M.; Rovezzi, M.; Gatzel, P.; Nagy, K. L.; Manceau, A. Divalent mercury from dissolved organic matter is bioavailable to fish and accumulates as dithiolate and tetrathiolate complexes. Environ. Sci. Technol. 2019, 53, 4880-4891. 
(19) Marcus, M. A.; MacDowell, A. A.; Celestre, R.; Manceau, A.; Miller, T.; Padmore, H. A.; Sublett, R. E. Beamline 10.3.2 at ALS: a hard X-ray microprobe for environmental and materials sciences. J. Synchrotron Radiat. 2004, 11, 239-247.

(20) Ressler, T. WinXAS: a program for X-ray absorption spectroscopy data analysis under MSWindows. J. Synchrotron Radiat. 1998, 5, 118-122.

(21) Ankudinov, A. L.; Rehr, J. J. Relativistic calculations of spin-dependent X-ray-absorption spectra. Phys. Rev. B 1997, 56, 1712-1716.

(22) Earley, J. W. Description and synthesis of the selenide minerals. Am. Miner. 1950, 35, 337364.

(23) Roman, M.; Sanchez, M. L. F.; Sanz-Medel, A.; Iglesias, H. G.; Cescon, P.; Barbante, C. Selenium speciation in rat colon tissues. J. Anal. Atom. Spectrom. 2011, 26, 100-108.

(24) Busto, M. E. D.; Oster, C.; Cuello-Nunez, S.; Deitrich, C. L.; Raab, A.; Konopka, A.; Lehmann, W. D.; Goenaga-Infante, H.; Fisicaro, P. Accurate quantification of selenoproteins in human plasma/serum by isotope dilution ICP-MS: focus on selenoprotein P. J. Anal. At. Spectrom. 2016, 31, 1904-1912.

(25) Sandalova, T.; Zhong, L. W.; Lindqvist, Y.; Holmgren, A.; Schneider, G. Three-dimensional structure of a mammalian thioredoxin reductase: Implications for mechanism and evolution of a selenocysteine-dependent enzyme. Proc. Natl. Acad. Sci. U.S.A. 2001, 98, 9533-9538.

(26) Pickering, I. J.; Cheng, Q.; Rengifo, E. M.; Nehzati, S.; Dolgova, N. V.; Kroll, T.; Sokaras, D.; George, G. N.; Arner, E. S. J. Direct observation of methylmercury and auranofin binding to selenocysteine in thioredoxin reductase. Inorg Chem. 2020, 59, 2711-2718.

(27) Ren, B.; Huang, W. H.; Akesson, B.; Ladenstein, R. The crystal structure of seleno-glutathione peroxidase from human plasma at $2.9 \AA$ resolution. J. Mol. Biol. 1997, 268, 869-885.

(28) Manceau, A.; Lemouchi, C.; Enescu, M.; Gaillot, A.-C.; Lanson, M.; Magnin, V.; Glatzel, P.; Poulin, B. A.; Ryan, J. N.; Aiken, G. R.; Gautier-Luneau, I.; Nagy, K. L. Formation of mercury sulfide from $\mathrm{Hg}(\mathrm{II})$-thiolate complexes in natural organic matter. Environ. Sci. Technol. 2015, 49, 9787-9796.

(29) Manceau, A.; Enescu, M.; Simionovici, A.; Lanson, M.; Gonzalez-Rey, M.; Rovezzi, M.; Tucoulou, R.; Glatzel, P.; Nagy, K. L.; Bourdineaud, J.-P. Chemical forms of mercury in human hair reveal sources of exposure. Environ. Sci. Technol. 2016, 50, 10721-10729.

(30) Møller, C.; Plesset, M. S. Note on an approximation treatment for many-electron systems. Phys. Rev. 1934, 46, 618-622.

(31) Neese, F. The ORCA program system. WIREs Comput. Mol. Sci. 2012, 2, 73-78.

(32) Manceau, A.; Lemouchi, C.; Rovezzi, M.; Lanson, M.; Glatzel, P.; Nagy, K. L.; GautierLuneau, I.; Joly, Y.; Enescu, M. Structure, bonding, and stability of mercury complexes with thiolate and thioether ligands from high-resolution XANES spectroscopy and first-principles calculations. Inorg. Chem. 2015, 54, 11776-11791.

(33) Schafer, A.; Horn, H.; Ahlrichs, R. Fully optimized contracted Gaussian-basis sets for atoms Li to Kr. J. Chem. Phys. 1992, 97, 2571-2577.

(34) Weigend, F.; Ahlrichs, R. Balanced basis sets of split valence, triple zeta valence and quadruple zeta valence quality for $\mathrm{H}$ to $\mathrm{Rn}$ : Design and assessment of accuracy. Phys. Chem. Chem. Phys. 2005, 7, 3297-3305.

(35) Feyereisen, M.; Fitzgerald, G.; Komornicki, A. Use of approximate integrals in ab initio theory - An application in MP2 energy calculations. Chem. Phys. Lett. 1993, 208, 359-363.

(36) Kendall, R. A.; Fruchtl, H. A. The impact of the resolution of the identity approximate integral method on modern ab initio algorithm development. Theor. Chem. Acc. 1997, 97, 158-163.

(37) Haussermann, U.; Dolg, M.; Stoll, H.; Preuss, H.; Schwerdtfeger, P.; Pitzer, R. M. Accuracy of energy-adjusted quasi-relativistic $a b$ initio pseudopotentials - All electron and pseudopotential benchmark calculations for $\mathrm{Hg}, \mathrm{HgH}$ and their cations. Mol. Phys. 1993, 78, 1211-1224.

(38) Marenich, A. V.; Cramer, C. J.; Truhlar, D. G. Universal solvation model based on solute electron density and on a continuum model of the solvent defined by the bulk dielectric constant and atomic surface tensions. Phys. Chem. B 2009, 113, 6378-6396. 
(39) Cattell, R. B. The scree test for the number of factors. J. Multiv. Behav. Res. 1996, 1, 245-276. (40) Rehr, J. J.; Mustre de Leon, J.; Zabinsky, S. I.; Albers, R. C. Theoretical X-ray absorption fine structure standards. J. Am. Chem. Soc. 1991, 113, 5135-5145.

(41) Teo, B. K. EXAFS: basic principles and data analysis. Springer-Verlag: Berlin, 1986; p 349.

(42) Crozier, E. D. A review of the current status of XAFS spectroscopy. Nucl. Instrum. Meth. B 1997, 133, 134-144.

(43) Roy, A.; Kucukural, A.; Zhang, Y. I-TASSER: a unified platform for automated protein structure and function prediction. Nature Protoc. 2010, 5, 725-738.

(44) Yang, J.; Yan, R.; Roy, A.; Xu, D.; Poisson, J.; Zhang, Y. The I-TASSER Suite: Protein structure and function prediction. Nat. Methods 2015, 12, 7-8.

(45) Burk, R. F.; Hill, K. E. Regulation of selenium metabolism and transport. In Annu. Rev. Nutr., Bowman, B. A.; Stover, P. J., Eds. 2015; Vol. 35, pp 109-134.

(46) DeLano, W. L. The PyMOL Molecular Graphics System. http://www.pymol.org 2002.

(47) Hidalgo, J.; Chung, R. S.; Penkowa, M.; Vasak, M. Structure and function of vertebrate metallothioneins. Met. Ions Life Sci. 2009, 5, 279-317.

(48) Digilio, G.; Bracco, C.; Vergani, L.; Botta, M.; Osella, D.; Viarengo, A. The cadmium binding domains in the metallothionein isoform Cd-7-MT10 from Mytilus galloprovincialis revealed by NMR spectroscopy. J. Biol. Inorg. Chem. 2009, 14, 167-178.

(49) Habjanic, J.; Zerbe, O.; Freisinger, E. A histidine-rich Pseudomonas metallothionein with a disordered tail displays higher binding capacity for cadmium than zinc. Metallomics 2018, 10, 14151429.

(50) Ralston, N. V. C.; Raymond, L. J. Mercury's neurotoxicity is characterized by its disruption of selenium biochemistry. BBA-Gen. Sub. 2018, 1862, 2405-2416.

(51) Sole, V. A.; Papillon, E.; Cotte, M.; Walter, P.; Susini, J. A multiplatform code for the analysis of energy-dispersive X-ray fluorescence spectra. Spectrochim. Acta, B 2007, 62, 63-68.

\section{S5. Cartesian coordinates of $\mathrm{Hg}(\text { Selenoneine })_{4}$ and $\mathrm{Hg}_{10}(\mathrm{SeMe})_{20}$}

\begin{tabular}{lrrrrrrr} 
Hg [Selenoneine] 4 & \multicolumn{5}{l}{ HglO(SeMe) 20} \\
$\mathrm{Hg}$ & 3.461701 & 4.146748 & 5.583562 & $\mathrm{Hg}$ & 6.014420 & -0.058675 & 0.371545 \\
$\mathrm{Se}$ & 2.706204 & 2.013233 & 6.875411 & $\mathrm{Hg}$ & -0.268486 & 6.515726 & 0.411108 \\
$\mathrm{Se}$ & 4.922708 & 4.001610 & 3.333475 & $\mathrm{Hg}$ & -0.253160 & 0.430061 & 6.310613 \\
$\mathrm{Se}$ & 5.232110 & 5.278112 & 7.089261 & $\mathrm{Hg}$ & 5.938762 & 6.269286 & 6.175340 \\
$\mathrm{Se}$ & 1.193700 & 5.029105 & 4.657621 & $\mathrm{Hg}$ & -0.155567 & 3.163920 & 3.116928 \\
$\mathrm{C}$ & 4.476669 & 1.607680 & 7.394439 & $\mathrm{Hg}$ & 5.984914 & 3.240218 & 3.043747 \\
$\mathrm{~N}$ & 5.423897 & 1.224327 & 6.487590 & $\mathrm{Hg}$ & 2.548632 & 0.020246 & 2.977366 \\
$\mathrm{~N}$ & 4.988642 & 1.697864 & 8.622831 & $\mathrm{Hg}$ & 3.151103 & 6.329468 & 2.859888 \\
$\mathrm{C}$ & 6.614491 & 1.079474 & 7.153129 & $\mathrm{Hg}$ & 2.920073 & 3.173796 & -0.766157 \\
$\mathrm{C}$ & 6.314848 & 1.369774 & 8.480903 & $\mathrm{Hg}$ & 3.197494 & 3.087935 & 6.342012 \\
$\mathrm{C}$ & 7.870810 & 0.569132 & 6.523838 & $\mathrm{Se}$ & 1.444574 & 1.863416 & 1.431035 \\
$\mathrm{H}$ & 7.004447 & 1.354284 & 9.326655 & $\mathrm{Se}$ & 1.795140 & 4.497964 & 4.416517 \\
$\mathrm{H}$ & 5.237060 & 1.111153 & 5.464794 & $\mathrm{Se}$ & 4.350104 & 1.597700 & 4.401854 \\
$\mathrm{C}$ & 8.245636 & 1.102636 & 5.132285 & $\mathrm{Se}$ & 4.441839 & 4.573375 & 1.325447 \\
$\mathrm{H}$ & 7.771604 & -0.513782 & 6.363167 & $\mathrm{Se}$ & 7.554977 & 1.392694 & 1.932403 \\
$\mathrm{H}$ & 8.701825 & 0.700246 & 7.234270 & $\mathrm{Se}$ & 7.328923 & -1.522043 & -1.319519 \\
$\mathrm{C}$ & 9.100078 & 0.031958 & 4.365074 & $\mathrm{Se}$ & 4.936997 & 1.842911 & -1.452448 \\
$\mathrm{O}$ & 8.599791 & -1.113986 & 4.414527 & $\mathrm{Se}$ & 3.892732 & -1.393875 & 1.209287 \\
$\mathrm{O}$ & 10.145865 & 0.379327 & 3.760442 & $\mathrm{Se}$ & 1.814804 & 7.912470 & 1.251024 \\
$\mathrm{~N}$ & 8.839878 & 2.507015 & 5.144193 & $\mathrm{Se}$ & 0.771487 & 4.391640 & -1.227576 \\
$\mathrm{C}$ & 10.186464 & 2.544438 & 5.788929 & $\mathrm{Se}$ & -1.579017 & 7.688114 & -1.476559 \\
$\mathrm{C}$ & 7.936086 & 3.437658 & 5.889650 & $\mathrm{Se}$ & -1.640263 & 5.149015 & 2.193377 \\
$\mathrm{C}$ & 8.935495 & 3.027086 & 3.741204 & $\mathrm{Se}$ & 1.106600 & 2.250149 & 7.660173 \\
$\mathrm{H}$ & 10.089642 & 2.212864 & 6.827122 & $\mathrm{Se}$ & 1.296942 & -1.302379 & 4.801895 \\
$\mathrm{H}$ & 10.855192 & 1.891119 & 5.225267 & $\mathrm{Se}$ & -1.777931 & 1.586978 & 4.434928 \\
$\mathrm{H}$ & 10.534462 & 3.582794 & 5.765039 & $\mathrm{Se}$ & -1.487740 & -1.257628 & 7.833693 \\
$\mathrm{H}$ & 6.928722 & 3.365774 & 5.463529 & $\mathrm{Se}$ & 7.688998 & 7.743364 & 7.381857
\end{tabular}




\begin{tabular}{|c|c|c|c|c|c|c|c|}
\hline & 7.926431 & 3.167904 & 6.948110 & $\mathrm{Se}$ & 7.506932 & 4.885899 & \\
\hline & 8.327102 & 4.453916 & 5.761155 & $\mathrm{Se}$ & 4.016526 & 7.617318 & 4.974804 \\
\hline & 9.61691 & 388822 & 3.179986 & $\mathrm{Se}$ & 5.038407 & & \\
\hline & 7.930301 & .000866 & 3.307192 & C & -2.577701 & 166898 & \\
\hline & 9.299819 & .059148 & 3.791551 & & -2.763118 & .081739 & \\
\hline & 7.325735 & .209258 & 4.536808 & & 2.866505 & 7.640337 & \\
\hline & 5.314390 & .207598 & 2.909719 & & 5.015315 & & \\
\hline & 6.062667 & .888638 & 1.816692 & & & 0858 & 19972 \\
\hline & 4.938404 & .086620 & 44192 & & & & -2 . \\
\hline & 6.192786 & 0.524961 & & & & & \\
\hline & 5.473034 & & & & & & \\
\hline & & -0.1 & & & & & \\
\hline & 34394 & 33 & 3.1 & & & & \\
\hline & 6.606628 & 2.5 & 1.2 & & & & \\
\hline & 8.461269 & 332 & 000 & & -1.8 & & \\
\hline & 6.534300 & 59 & -0. & & & & \\
\hline & 6.697426 & -1.2 & 0 & & & & \\
\hline & 8.853129 & 1.2 & -0.1 & & -2. & & \\
\hline & 8.286205 & 2.33 & & & & -1.4 & \\
\hline & 9.647899 & 1.1 & -1.1 & $C$ & & -2 & \\
\hline & & -1.236191 & & C & & & \\
\hline & & -1.7 & -0 & $\mathrm{C}$ & & -0 . & \\
\hline & & -2.3 & & C & & & \\
\hline & 10.68 & -0.9 & & $H$ & -1 & & -2 . \\
\hline & 89 & -1.8 & -1 & & -3. & & -3 \\
\hline & 9.37 & 0.9 & -1.7 & & -3.3 & 44 & -1 \\
\hline & 9.52 & 2.6 & -1.0 & & & 15 & -2 \\
\hline & & -1.8 & & & & & -3 \\
\hline & & -2.7 & & & & & \\
\hline & 9.5 & -3.1 & & $\mathrm{H}$ & & -0 . & -2 . \\
\hline & 11.0 & -0.2 & -0 . & $\mathrm{H}$ & & & -3 \\
\hline & & -0.6 & & $\mathrm{H}$ & & -0 . & \\
\hline & & -1.9 & & & & -0 . & -0 . \\
\hline & & 0.2 & & & & & -1 \\
\hline & & 6.1 & & & & -1 & -1 \\
\hline & 2.99 & 41 & & & & 2. & -0 \\
\hline & 4.1 & 83 & & & & & \\
\hline & 2.35 & 55 & & & & & \\
\hline & & & 10. & $\mathrm{H}$ & & & \\
\hline & & & & $\mathrm{H}$ & & & \\
\hline & & & 11. & $\mathrm{H}$ & & & \\
\hline & & & & $\mathrm{H}$ & & & \\
\hline & -0 . & & & $\mathrm{H}$ & & & \\
\hline & & 6 & & $\mathrm{H}$ & & & \\
\hline & & 59 & & $\mathrm{H}$ & & & \\
\hline & -1.358582 & & & & & & \\
\hline & -1.982 & & & & & & \\
\hline & -1.630013 & & & $\mathrm{H}$ & & & -0 . \\
\hline & -0.463185 & 5.979873 & 8.98 & $\mathrm{H}$ & 7814 & 8.087540 & -0.225905 \\
\hline & -0.602789 & 6.239615 & 10.443706 & $\mathrm{H}$ & & & -1.193229 \\
\hline & 0.552443 & & & $\mathrm{H}$ & & & \\
\hline & -1.765 & & & $\mathrm{H}$ & & & \\
\hline & & & & $\mathrm{H}$ & & & \\
\hline & -1.26 & & & $\mathrm{H}$ & & & \\
\hline & -1.02 & & 10. & $\mathrm{H}$ & & -0.2 & \\
\hline & & & & $\mathrm{H}$ & & -0.713754 & \\
\hline & & & & $\mathrm{H}$ & & -3.068435 & \\
\hline & 0.180134 & 3.985629 & 9.214665 & $\mathrm{H}$ & -3.184353 & -1.559457 & 5.94353 \\
\hline
\end{tabular}




$\begin{array}{rrrrrrrr}\mathrm{H} & -2.571333 & 6.129948 & 8.759431 & \mathrm{H} & -1.731876 & -2.579941 & 5.659929 \\ \mathrm{H} & -1.701657 & 5.388058 & 7.372097 & \mathrm{H} & 1.137887 & 0.719148 & 9.649280 \\ \mathrm{H} & -1.921706 & 4.464143 & 8.905460 & \mathrm{H} & 2.532136 & 0.338636 & 8.586185 \\ \mathrm{H} & 0.206007 & 6.878728 & 7.225946 & \mathrm{H} & 2.579041 & 1.785807 & 9.650208 \\ \mathrm{C} & 1.384638 & 6.901459 & 4.696856 & \mathrm{H} & 7.404312 & 3.432219 & 7.872218 \\ \mathrm{~N} & 0.441676 & 7.748462 & 4.205295 & \mathrm{H} & 6.674932 & 2.939355 & 6.313917 \\ \mathrm{~N} & 2.395108 & 7.598284 & 5.230934 & \mathrm{H} & 6.260575 & 2.054166 & 7.825434 \\ \mathrm{C} & 0.839380 & 9.037902 & 4.444784 & \mathrm{H} & 0.049655 & 6.262629 & 4.888000 \\ \mathrm{C} & 2.065257 & 8.926150 & 5.085920 & \mathrm{H} & 1.383194 & 6.348129 & 6.086926 \\ \mathrm{C} & -0.009938 & 10.208516 & 4.073822 & \mathrm{H} & 0.130640 & 5.068963 & 6.227798 \\ \mathrm{H} & 2.714215 & 9.727207 & 5.440882 & \mathrm{H} & 5.219987 & 5.751736 & -0.763293 \\ \mathrm{H} & -0.479433 & 7.549914 & 3.785547 & \mathrm{H} & 6.587330 & 4.924801 & 0.038130 \\ \mathrm{C} & -1.440305 & 10.056503 & 4.642710 & \mathrm{H} & 5.994666 & 6.492895 & 0.673539 \\ \mathrm{H} & -0.052853 & 10.331025 & 2.979355 & \mathrm{H} & 5.284887 & -0.112503 & 6.026284 \\ \mathrm{H} & 0.490467 & 11.107074 & 4.456184 & \mathrm{H} & 5.856528 & -0.416584 & 4.354237 \\ \mathrm{C} & -2.370958 & 9.503238 & 3.527842 & \mathrm{H} & 6.601344 & 0.886101 & 5.329208 \\ \mathrm{O} & -2.051544 & 8.338502 & 3.167480 & \mathrm{H} & 3.926817 & -3.285435 & 2.868528 \\ \mathrm{O} & -3.292554 & 10.205034 & 3.059991 & \mathrm{H} & 5.330827 & -3.388222 & 1.758390 \\ \mathrm{~N} & -1.934200 & 11.308615 & 5.346992 & \mathrm{H} & 5.360154 & -2.234158 & 3.128720 \\ \mathrm{C} & -1.962584 & 12.499479 & 4.448331 & \mathrm{H} & 2.321972 & -1.949164 & 6.996786 \\ \mathrm{C} & -1.055172 & 11.596550 & 6.522633 & \mathrm{H} & 3.558620 & -2.001895 & 5.702565 \\ \mathrm{C} & -3.303404 & 11.040224 & 5.892413 & \mathrm{H} & 3.059782 & -0.422316 & 6.409620 \\ \mathrm{H} & -0.937738 & 12.739649 & 4.148426 & \mathrm{H} & -0.314238 & 1.437707 & -0.321754 \\ \mathrm{H} & -2.578651 & 12.252913 & 3.581995 & \mathrm{H} & -0.304458 & 0.094089 & 0.871688 \\ \mathrm{H} & -2.388122 & 13.336519 & 5.012871 & \mathrm{H} & 0.969588 & 0.185795 & -0.382365 \\ & & & & \mathrm{H} & -1.113486 & 10.747463 & 7.212104 \\ & & & & \mathrm{H} & -0.027473 & 11.761020 & 6.189701 \\ & & & & \mathrm{H} & -1.433117 & 12.504484 & 7.005355 \\ & & & & \mathrm{H} & -3.990983 & 10.908874 & 5.056052 \\ & & & & \mathrm{H} & -3.237230 & 10.131552 & 6.501737 \\ & & & & \mathrm{H} & -3.592522 & 11.896897 & 6.510645 \\ & & & & \mathrm{H} & -1.431745 & 9.303615 & 5.444663\end{array}$

